\title{
ENZIMAS FIBROLÍTICAS E EMURCHECIMENTO NO CONTROLE DE PERDAS DA ENSILAGEM E NA DIGESTÃO DE NUTRIENTES EM BOVINOS ALIMENTADOS COM RAÇÕES CONTENDO SILAGEM DE CAPIM TANZÂNIA
}

\section{DANiEle REbouças SANTANA LOURES}

Tese apresentada à Escola Superior de Agricultura "Luiz de Queiroz", Universidade de São Paulo, para obtenção do título de Doutor em Agronomia, Área de Concentração: Ciência Animal e Pastagens.

P I R A C I C A B A

Estado de São Paulo - Brasil

Fevereiro - 2004 


\section{ENZIMAS FIBROLÍTICAS E EMURCHECIMENTO NO CONTROLE DE PERDAS DA ENSILAGEM E NA DIGESTÃO DE NUTRIENTES EM BOVINOS ALIMENTADOS COM RAÇÕES CONTENDO SILAGEM DE CAPIM TANZÂNIA}

\section{Daniele Rebouças Santana Loures}

Zootecnista

Orientador: Prof. Dr. LUIZ GUSTAVO NUSSIO

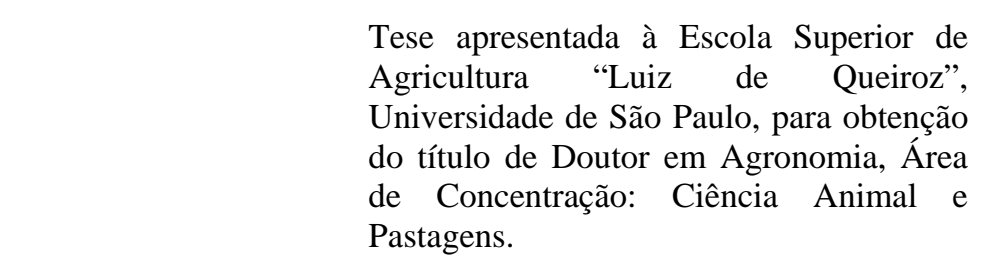

P I R A C I C A B A

Estado de São Paulo - Brasil

Fevereiro - 2004 


\section{Dados Internacionais de Catalogação na Publicação (CIP) DIVISÃO DE BIBLIOTECA E DOCUMENTAÇÃO - ESALQ/USP}

\section{Loures, Daniele Rebouças Santana}

Enzimas fibrolíticas e emurchecimento no controle de perdas da ensilagem e na digestão de nutrientes em bovinos alimentados com rações contendo silagem de capim Tanzânia / Daniele Rebouças Santana Loures. - - Piracicaba, 2004.

$146 \mathrm{p}$.

Tese (doutorado) - Escola Superior de Agricultura Luiz de Queiroz, 2004. Bibliografia.

1. Aditivos alimentares 2. Bovinos de corte 3. Capim-Tanzânia 4.Comportamento ingestivo animal 5. Digestibilidade 6. Ensilagem 


\section{Aprender}

"Depois de algum tempo você aprende a diferença, a sutil diferença, entre dar a mão e acorrentar uma alma.

E você aprende que amar não significa apoiar-se, e que a companhia nem sempre significa segurança.

E começa a aprender que beijos não são contratos e presentes não são promessas.

E começa a aceitar suas derrotas com a cabeça erguida e os olhos adiante, com a graça de um adulto e não com a tristeza de uma criança.

E aprende a construir todas as suas estradas no hoje, porque o terreno do amanhã é incerto demais para os planos, e o futuro tem o costume de cair em meio ao vão.

Depois de um tempo você aprende que o sol queima se ficar exposto por muito tempo.

E aprende que não importa o quanto você se importe, algumas pessoas simplesmente não se importam...

E aceita que não importa quão boa seja uma pessoa, ela vai feri-lo de vez em quando e você precisa perdoá-la por isso.

Descobre que se levam anos para se construir confiança e apenas segundos para destruí-la, $e$ que você pode fazer coisas em um instante, das quais se arrependerá pelo resto da vida.

Aprende que verdadeiras amizades continuam a crescer mesmo a longas distâncias.

E o que importa não é o que você tem na vida, mas quem você tem na vida.

Aprende que não temos que mudar os amigos se compreendermos que os amigos mudam, percebe que seu melhor amigo e você podem fazer qualquer coisa, ou nada, e ter bons momentos juntos.

Descobre que as pessoas com quem você mais se importa na vida são tomadas de você muito depressa, por isso sempre devemos deixar as pessoas que amamos com palavras 
amorosas: pode ser a última vez que a vejamos.

Aprende que as circunstâncias e os ambientes têm influência sobre nós, mas nós somos responsáveis por nós mesmos.

Começa a aprender que não se deve comparar com os outros, mas com o melhor que pode ser.

Aprende que ou você controla seus atos ou eles o controlarão, e que ser flexível não significa ser fraco ou não ter personalidade, pois não importa quão delicada e ágil seja uma situação, sempre existem dois lados.

Aprende que heróis são pessoas que fizeram o que era necessário fazer, enfrentando as conseqüências.

Aprende que paciência requer muita prática.

Aprende que há mais dos seus pais em você do que você supunha.

Aprende que quando está com raiva tem o direito de estar com raiva, mas isso não te dá o direito de ser cruel.

Aprende que com a mesma severidade com que julga, você será em algum momento condenado. Aprende que não importa em quantos pedaços seu coração foi partido, o mundo não pára para que você o conserte.

Aprende que o tempo não é algo que possa voltar para trás.

Portanto, plante seu jardim e decore sua alma em vez de esperar que alguém lhe traga flores.

$E$ você aprende que realmente pode suportar... que realmente é forte, e que pode ir muito mais longe depois de pensar que não se pode mais.

E que realmente a vida tem valor e que você tem valor diante da vida.

Nossas dúvidas são traidoras e nos fazem perder o bem que poderíamos conquistar, se não fosse o medo de tentar". 
À minha família,

Aos meus pais, Lívia e Emílio, aos irmãos, Paula e Emílio Carlos, à Luciana, aos sobrinhos, Gabriel e Cecília, e ao Raul, por estarem do meu lado nas mais difíceis situações, pelo apoio, pelas alegrias e pela força que sempre transmitiram ao longo dos anos. Aos meus tios, em especial ao tio Cyro, pela verdadeira lição de força e perseverança com seus 80 anos, e à tia Cyrene, por seu carinho e ternura. A todos os tios e primos que não foram citados, mas que parte fazem de minha vida e pelos quais tenho grande carinho. Enfim, a essa família grande e tão maravilhosa, que só tenho a agradecer a Deus por isso.

Dedico 


\section{AGRADECIMENTOS}

Ao Prof. Dr. Luiz Gustavo Nussio, pela elaboração do projeto e pelo profissionalismo no decorrer do curso, e também à sua família: Carla, Clara e Vitor.

À Escola Superior de Agricultura Luiz de Queiroz (USP), em especial ao Departamento de Zootecnia - Setor de Ruminantes, pela oportunidade de realização deste curso.

À Fundação de Amparo à Pesquisa do Estado de São Paulo (FAPESP), pela concessão da bolsa de estudos durante o transcorrer do curso e pelo financiamento do projeto através dos recursos disponibilizados na reserva técnica da bolsa.

Ao Prof. Dr. Alexandre Vaz Pires, pela execução das cirurgias.

Ao Prof. Dr. Flávio Augusto Portela Santos, pelo auxílio e pela colaboração no trabalho e na formulação das dietas.

Ao Prof. Dr. Irineu Umberto Packer, pelo auxílio e pelas sugestões na análise estatística dos dados.

Ao Prof. Dr. Ricardo Andrade Reis, pelo grande apoio e pelas valiosas colaborações e sugestões para o aprimoramento do trabalho.

Ao Prof. Dr. Sila Carneiro da Silva, por sua prestabilidade na coordenação do curso de pós-graduação.

Ao Prof. Dr. Wilson Roberto Soares Mattos, pelas sugestões, pelo apoio, pela amizade e pela participação na redação do trabalho.

Aos demais professores do Departamento de Zootecnia, pelos ensinamentos, pela cordialidade e pela amizade.

Aos estagiários Sérgio, Eduardo, Camilo, Ricardo e Alessandro, pela dedicação na condução do experimento no campo.

Ao Raul, pela grande ajuda, compreensão e pelo apoio nos momentos mais difíceis, 
sendo ele responsável por boa parte do mérito deste trabalho.

Aos amigos André, Solidete, Lucas, Sérgio, Soraia, Gica, Henrique, Luciana, Rodrigo, José Leonardo, Maity, Michele, Marta, Patrick, Maria, Luizinho, Lua e Hugo, pelo apoio, pela amizade e pelo auxílio direto e indireto na condução do experimento.

Ao amigo Dr. Fábio Prudêncio de Campos, pelo auxílio na correção do trabalho escrito e por sua amizade.

Ao funcionário do Laboratório de Bromatologia do Departamento de Zootecnia Carlos César Alves, pela amizade, paciência e pelos ensinamentos durante as análises laboratoriais.

Aos demais funcionários e colegas do curso de pós-graduação, pela amizade, pela ajuda e pela agradável convivência.

Às pessoas que contribuíram de alguma forma para a realização deste trabalho. 


\section{SUMÁRIO}

\section{Página}

LISTA DE FIGURAS.....................................................................................

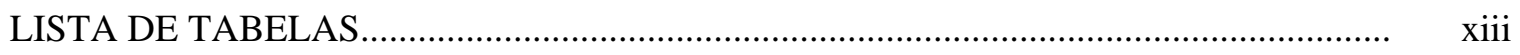

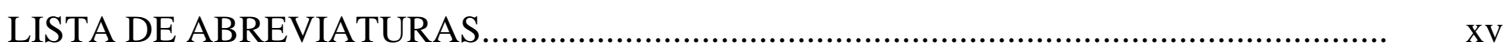

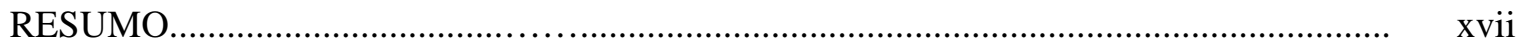

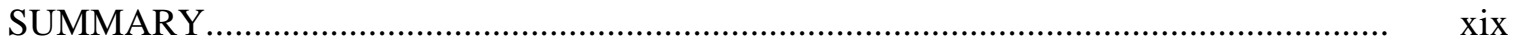

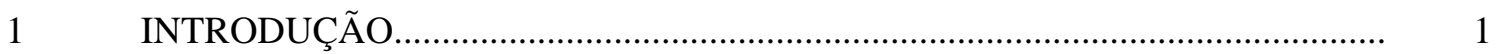

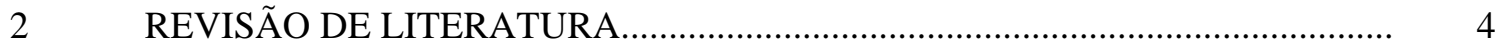

2.1 Processo fermentativo, valor nutritivo da silagem e uso de aditivos.......................... 4

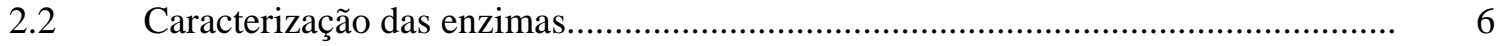

2.3 Fatores que devem ser considerados na avaliação da ação das enzimas fibrolíticas no processo de conservação da forragem.................................................................... 8

2.3.1 Tamanho de partícula....................................................................................... 8

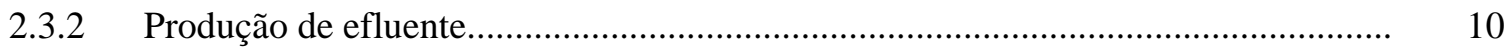

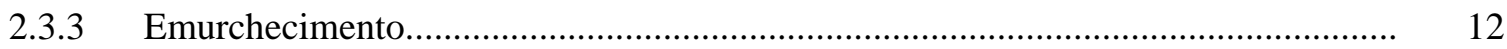

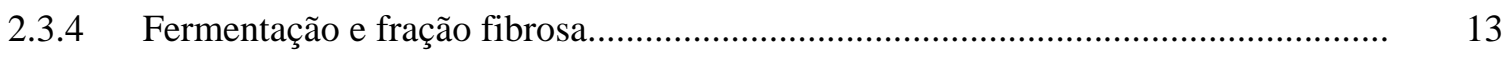

2.4 Efeito das enzimas fibrolíticas na digestão de nutrientes e no desempenho de

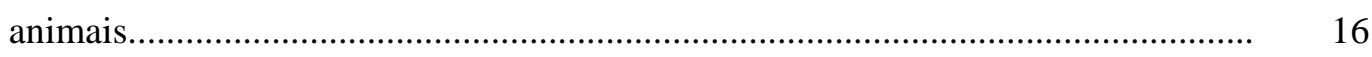

3 CONTROLE DE PERDAS NA ENSILAGEM DE CAPIM TANZÂNIA SOB OS EFEITOS DO TEOR DE MATÉRIA SECA, TAMANHO DE PARTÍCULA E DO USO DE ENZIMAS FIBROLÍTICAS NA PRESENÇA OU NÃO DE

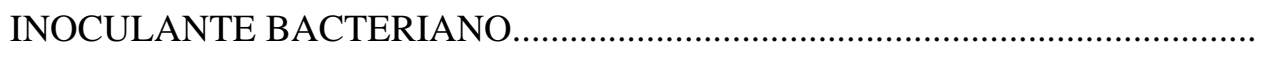




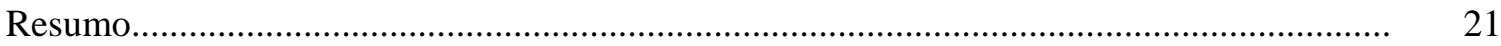

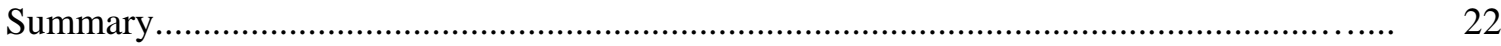

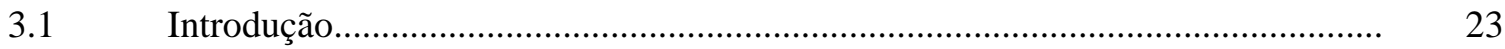

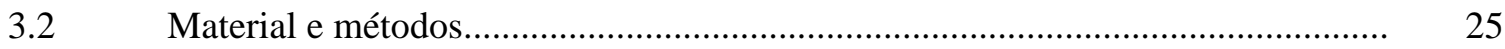

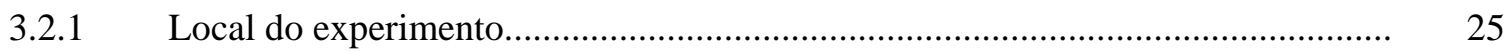

3.2.2 Forragem, tratamento e coleta de amostras........................................................ 25

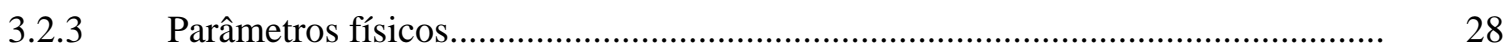

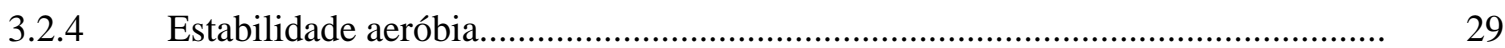

3.2.5 Determinação das perdas de MS por gases e efluente e de sua taxa de recuperação................................................................................................ 29

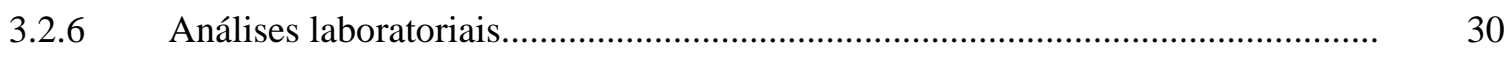

3.2.7 Delineamento experimental e análises estatísticas............................................... 32

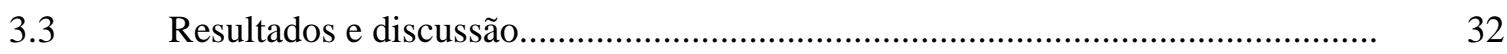

3.3.1 Características do capim Tanzânia utilizado na ensilagem................................... 32

3.3.2 Avaliação das silagens experimentais.................................... 34

3.3.2.1 Granulometria e parâmetros físicos...................................... 34

3.3.2.2 Estabilidade aeróbia.................................................... 37

3.3.2.3 Condutividade elétrica................................................... 41

3.3.2.4 Matéria seca e proteína bruta......................................... 43

3.3.2.5 Degradação da parede celular............................................ 45

3.3.2.6 Digestibilidade in vitro da matéria seca e teor de carboidratos solúveis............. 49

3.3.2.7 Parâmetros da fermentação da silagem................................... 52

3.3.3 Avaliação das perdas no processo fermentativo.............................. 56

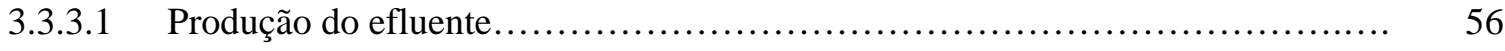

3.3.3.2 Composição do efluente............................................... 59

3.3.3.3 Perdas por efluente e gases e taxa de recuperação de matéria seca....................... 62

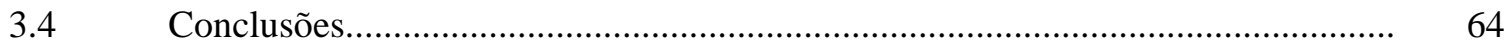

4 USO DE ENZIMAS FIBROLÍTICAS E DO TEOR DE MATÉRIA SECA EM SILAGEM DE CAPIM TANZÂNIA NA DIGESTÃO DE NUTRIENTES, PARÂMETROS RUMINAIS E COMPORTAMENTO INGESTIVO EM BOVINOS DE CORTE.................................................................................. 66

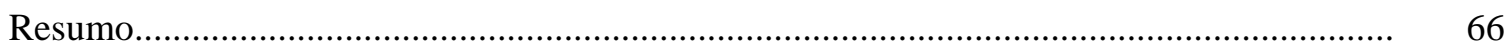


Summary......

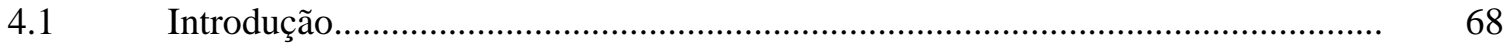

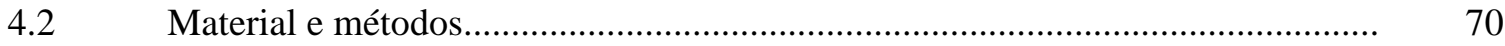

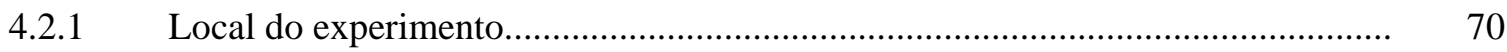

4.2.2 Forragem, animais utilizados e período experimental............................................. 70

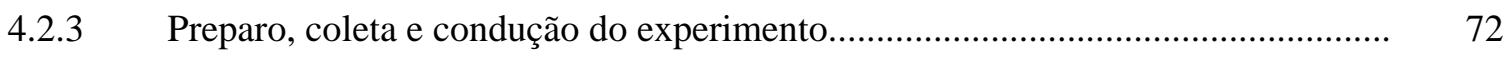

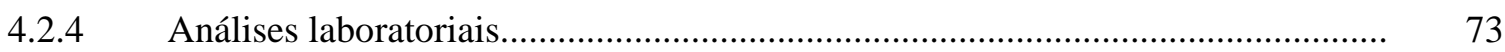

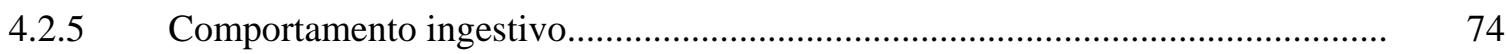

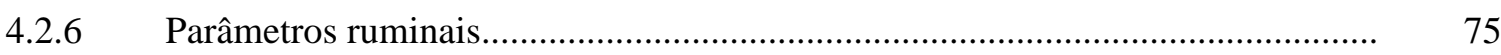

4.2.7 Avaliação da taxa de passagem de sólidos e líquidos........................................... 76

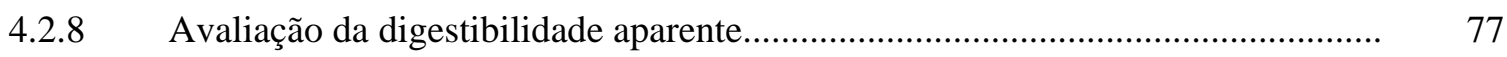

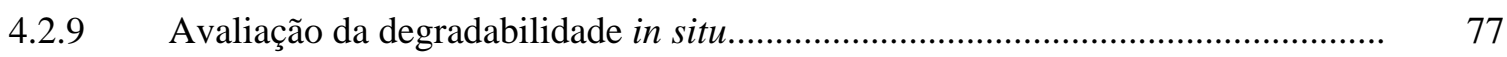

4.2.10 Delineamento experimental e análises estatísticas................................................... 79

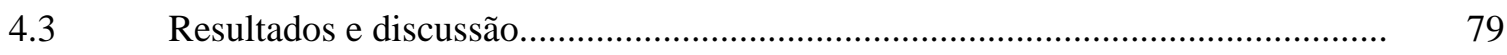

4.3.1 Avaliação das dietas experimentais..................................................................... 79

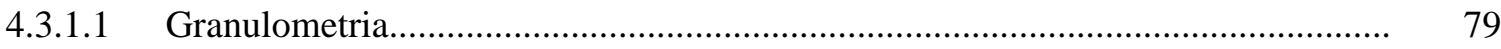

4.3.1.2 Participação de nutrientes e composição bromatológica das rações........................ 81

4.3.2 Cinética, ingestão e comportamento ingestivo dos animais................................... 86

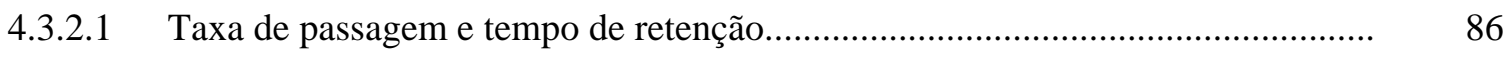

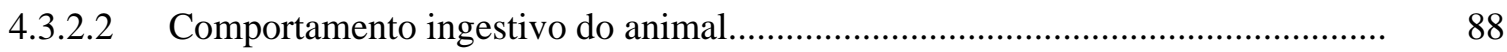

4.3.2.3 Ingestão de matéria seca...................................................................................... 92

4.3.3 Características da fermentação ruminal................................................................ 95

4.3.3.1 pH, ácidos graxos voláteis e nitrogênio amoniacal............................................... 95

4.3.3.1.1 Evolução temporal da concentração do pH ruminal................................................ 100

4.3.4 Digestibilidade aparente no trato digestivo.............................................................. 104

4.3.5 Degradabilidade in situ....................................................................................... 107

4.3.5.1 Degradabilidade da matéria seca........................................................................... 107

4.3.5.2 Degradabilidade da fração fibrosa........................................................................... 110

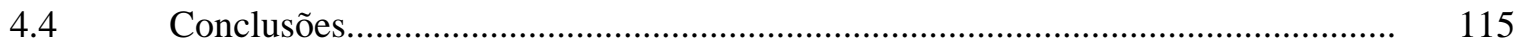

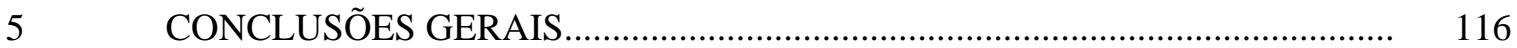

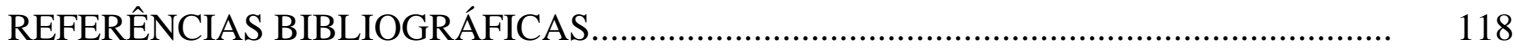




\section{LISTA DE FIGURAS}

1 Efeito de interação do conteúdo de matéria seca e enzimas fibrolíticas sobre o teor de FDN nas silagens de capim Tanzânia.......................................................... 46

2 Efeito do conteúdo de matéria seca e de enzimas fibrolíticas sobre o teor de hemicelulose nas silagens de capim Tanzânia........................................................... 48

3 Efeito de interação do conteúdo de matéria seca e enzimas fibrolíticas sobre o teor de lignina nas silagens de capim Tanzânia....................................................... 48

4 Efeito de interação do conteúdo de matéria seca e enzimas fibrolíticas sobre a digestibilidade in vitro da MS nas silagens de capim Tanzânia.............................

5 Efeito do conteúdo de matéria seca e de enzimas fibrolíticas sobre o teor de carboidratos solúveis nas silagens de capim Tanzânia...........................................

6 Efeito de interação do conteúdo de matéria seca e enzimas fibrolíticas sobre o pH nas silagens de capim Tanzânia...........................................................................................

7 Efeito de interação do conteúdo de matéria seca e enzimas fibrolíticas sobre o teor nitrogênio amoniacal (\% N total) nas silagens de capim Tanzânia................................

8 Quantidade de efluente observada (mL) em um período de 136 dias de armazenamento, em silagens de capim Tanzânia emurchecido 
9 Efeito das dietas experimentais sobre a evolução temporal do pH no fluido

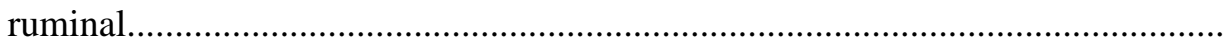

10 Efeito das dietas experimentais sobre a evolução temporal do nitrogênio

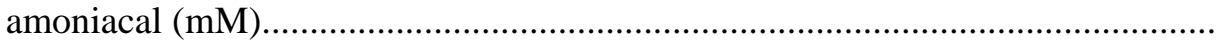

11 Efeito das dietas experimentais sobre a evolução temporal da concentração total dos ácidos graxos voláteis. 


\section{LISTA DE TABELAS}

1 Composição química e pH do capim Tanzânia utilizado na ensilagem.

Página

33

2 Retenção percentual de partículas de capim Tanzânia, utilizando-se método “Penn State Particle Size Separator” adaptado.

3 Parâmetros físicos da silagem de capim Tanzânia com diferentes teores de MS, tamanho de partícula e aplicações enzimáticas.

4 Variáveis consideradas na avaliação da estabilidade aeróbia em silagens de capim Tanzânia com e sem adição de enzimas fibrolíticas................................

5 Composição química das silagens de capim Tanzânia com e sem adição de

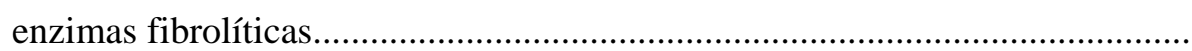

6 Composição do efluente da silagem de capim Tanzânia com diferentes teores de MS, tamanho de partícula e aplicações enzimáticas......................................

7 Taxa de recuperação da MS, perdas por gases e efluente, em percentagem de matéria seca, nas silagens de capim Tanzânia com diferentes teores de MS, tamanho de partícula e aplicações enzimáticas.....................................................

8 Características bromatológicas e fermentativas das silagens de capim Tanzânia com e sem adição de enzimas fibrolíticas e composição bromatológica do concentrado

9 Composição bromatológica calculada para as rações experimentais com base na taxa de inclusão e composição dos ingredientes. 
10 Taxas de passagem de sólidos da silagem e de líquidos em bovinos que receberam rações contendo silagem de capim Tanzânia com e sem adição de enzimas fibrolíticas.

11 Variáveis do comportamento ingestivo em bovinos que receberam rações contendo silagem de capim Tanzânia com e sem adição de enzimas fibrolíticas.

12 Quadrados mínimos para o consumo de matéria seca e de FDN em bovinos tratados com rações contendo silagem de capim Tanzânia com e sem adição de enzimas fibrolíticas.

13 Médias dos quadrados mínimos das variáveis ruminais observadas em bovinos tratados com rações contendo silagens de capim Tanzânia com e sem adição de enzimas fibrolíticas.

14 Evolução temporal das médias dos quadrados mínimos para os parâmetros ruminais observados em bovinos tratados com rações contendo silagens de capim Tanzânia com e sem adição de enzimas fibrolíticas.

15 Quadrados mínimos para a digestibilidade e ingestão de nutrientes digestíveis para matéria seca, matéria orgânica, FDN, FDA e hemicelulose em bovinos que receberam rações contendo silagens de Tanzânia com e sem adição de enzimas fibrolíticas.

16 Variáveis da degradabilidade in situ da matéria seca de silagens de capim Tanzânia com e sem adição de enzimas fibrolíticas.

17 Variáveis da degradabilidade in situ da fibra em detergente neutro de silagens de capim Tanzânia com e sem adição de enzimas fibrolíticas..

18 Variáveis da degradabilidade in situ da fibra em detergente ácido de silagens de capim Tanzânia com e sem adição de enzimas fibrolíticas...

19 Variáveis da degradabilidade in situ da hemicelulose de silagens de capim Tanzânia com e sem adição de enzimas fibrolíticas. 


\section{LISTA DE ABREVIATURAS}

AGVs: Ácidos graxos voláteis

B: Inoculante bacteriano

C2: Ácido acético

C3: $\quad$ Ácido propiônico

C4: $\quad$ Ácido butírico

CI4: $\quad$ Ácido isobutírico

C5: Ácido valérico

CI5: Ácido isovalérico

CE: $\quad$ Condutividade elétrica

CHOs: Carboidratos solúveis

CNF: Carboidratos não-fibrosos

CEL: Celulose

DBO: Demanda bioquímica de oxigênio

DQO: Demanda química de oxigênio

DIVMS: Digestibilidade in vitro da matéria seca

E: $\quad$ Efeito de enzimas isoladas ou combinadas com inoculante bacteriano

EE: $\quad$ Extrato etéreo

EM: $\quad$ Emurchecido

ENZ: Enzima fibrolítica

FDA: Fibra em detergente ácido

FDN: $\quad$ Fibra em detergente neutro

HEMI: Hemicelulose

ln: $\quad$ Logaritmo neperiano 
MM: Matéria mineral

MO: $\quad$ Matéria orgânica

$\mathrm{N}$ : Nitrogênio

$\mathrm{N}-\mathrm{NH}^{3}$ Nitrogênio amoniacal

PB: Proteína bruta

SE: $\quad$ Sem emurchecimento

TR: $\quad$ Tempo de retenção

TP: Tamanho de partícula

UFC: Unidades formadoras de colônias 


\title{
ENZIMAS FIBROLÍTICAS E EMURCHECIMENTO NO CONTROLE DE PERDAS DA ENSILAGEM E NA DIGESTÃO DE NUTRIENTES EM BOVINOS ALIMENTADOS COM RAÇÕES CONTENDO SILAGEM DE CAPIM TANZÂNIA
}

\author{
Autor: DANIELE REBOUÇAS SANTANA LOURES \\ Orientador: Prof. Dr. LUIZ GUSTAVO NUSSIO
}

\section{RESUMO}

Este trabalho teve por objetivo avaliar o efeito de enzimas fibrolíticas na degradação da parede celular do volumoso, quando aplicadas antes da ensilagem e no momento da alimentação do animal. No experimento I analisou-se o efeito do emurchecimento, da redução do tamanho de partículas e da adição de enzimas fibrolíticas (associadas ou não ao inoculante bacteriano Lactobacillus plantarum) na fermentação e nas perdas do processo de ensilagem de capim Tanzânia (Panicum maximum, Jacq. cv. Tanzânia). A forragem foi cortada aos 45 dias de crescimento vegetativo e armazenada em silos experimentais (50 L) durante 136 dias. Durante o período de armazenamento o efluente foi coletado e quantificado no $1^{\underline{0}}, 2^{\underline{0}}, 7^{\frac{0}{}}, 14^{\underline{0}}, 21^{\underline{0}}$, $60^{\circ}, 90^{\circ}$ e $136^{\circ}$ dias. A redução do tamanho de partícula não influenciou as perdas totais, embora o tamanho menor tenha contribuído para garantir maior estabilidade aeróbia da silagem. A taxa de recuperação e as perdas de MS por efluente e gases foram de 72, 5 e $23 \%$ nas silagens não-emurchecidas e de 80,0 e $21 \%$ nas silagens emurchecidas, 
respectivamente. A adição de enzimas fibrolíticas associadas ou não ao inoculante bacteriano promoveu redução da fração fibrosa (FDN, FDA, celulose, hemicelulose), sendo esta redução mais acentuada nas silagens emurchecidas. Contudo, não houve aumento da digestibilidade in vitro da MS com adição de enzimas fibrolíticas. Foram observados os valores médios de DBO (11.289 $\mathrm{mg} \mathrm{L}^{-1}$ ), DQO (36.279 $\mathrm{mg} \mathrm{L}^{-1}$ ) e DQO/DBO $(3,35)$ no efluente das silagens contendo umidade original; o maior período de armazenamento aumentou significativamente o potencial poluidor do efluente. $\mathrm{O}$ experimento II teve por objetivo avaliar o efeito do conteúdo de matéria seca da forragem e o uso de enzimas fibrolíticas aplicadas durante a ensilagem de capim Tanzânia ou após a abertura do silo. Os tratamentos foram confeccionados da seguinte forma: A - forragem emurchecida sem aplicação de enzimas; B - não-emurchecida sem aplicação de enzimas; $\mathrm{C}$ - emurchecida com enzimas ( $2 \mathrm{~L} \mathrm{t}^{-1}$ de massa verde); $\mathrm{D}$ - nãoemurchecida com enzimas; e $\mathrm{E}$ - não-emurchecida com enzimas $\left(10 \mathrm{~L} \mathrm{t}^{-1}\right.$ de massa verde), após a abertura do silo. Cinco novilhos da raça Nelore foram distribuídos ao acaso em delineamento do tipo Quadrado Latino 5 x 5. Os parâmetros de cinética de passagem de sólidos $\left(2,23 \%\right.$ hora $\left.^{-1}\right)$ e de líquidos $\left(4,83 \%\right.$ hora $\left.^{-1}\right)$ foram similares para os tratamentos avaliados. O comportamento ingestivo dos animais não foi alterado com a elevação da concentração de MS da silagem, sendo observados os seguintes tempos (minutos dia ${ }^{-1}$ ) e taxas (min kg MSI${ }^{-1}$ ) de ingestão de MS (247 e 24), de ruminação (426 e 43) e de mastigação (673 e 67), respectivamente. As médias das concentrações totais dos ácidos graxos voláteis $(109,62 \mathrm{mM})$ e de nitrogênio amoniacal $\left(5,6 \mathrm{mg} \mathrm{dL}^{-1}\right)$, do fluido ruminal, não foram alteradas pelos tratamentos aplicados. Diante dessas observações, pode-se concluir que o emurchecimento da forragem e o uso de aditivo enzimático não resultaram em alterações significativas no comportamento ingestivo, nos parâmetros ruminais e na digestibilidade de nutrientes em animais. 


\title{
FIBROLYTIC ENZYMES AND WILTING TO CONTROL ENSILING LOSSES AND NUTRIENT DIGESTION IN BOVINE FED WITH TANZANIA GRASS SILAGE BASED RATIONS
}

\author{
Author: DANIELE REBOUÇAS SANTANA LOURES
}

Adviser: Prof. Dr. LUIZ GUSTAVO NUSSIO

\section{SUMMARY}

The present trial aimed to evaluate the effect of fibrolytic enzymes on forage cell wall degradation, when applied either during the ensiling process or just before the animal feeding. The experiment I analyzed the effects of wilting (wet vs wilted), particle size reduction (small vs large) and the addition of fibrolytic enzymes (alone vs combined with Lactobacillus plantarum) on the fermentation and ensiling losses of Tanzania grass (Panicum maximum, Jacq. cv. Tanzania). Forage was harvested and cut at 45-day vegetative re-growth period and stored in experimental plastic silos (50 L) during 136 days. During the storage period, the effluent flow was collected and measured at days 1 , 2, 7, 14, 21, 60, 90 and 136. Total silage losses were not affected by particle size reduction, even though the smallest particle size promoted better aerobic stability of the silage. The rate of silage DM recovery, effluent and gases losses were 72,5 e $23 \%$ for wet and 80 , 0 e $21 \%$ for wilted silages, respectively. The addition of fibrolytic enzymes 
exclusively or combined with Lactobacillus plantarum led to decreased concentrations of NDF, ADF, cellulose and hemicellulose mainly on wilted silages, however, no benefit was observed in the in vitro DM digestibility. Mean values for BOD (11.289 $\left.\mathrm{mg} \mathrm{L}^{-1}\right)$, COD (36.279 $\mathrm{mg} \mathrm{L}^{-1}$ ), and the ratio COD/BOD (3.35) were observed on the effluent of wet silages, which increased the potential of environmental pollution with the longer silage storage period. The experiment II aimed to study the effects of forage wilting or fibrolytic enzymes addition to the Tanzania grass silages. Treatments consisted of: A wilted forage without enzymes; B - fresh forage without enzymes; C - wilted forage with enzymes at ensiling ( $2 \mathrm{~L} \mathrm{t}^{-1}$ wet forage); $\mathrm{D}$ - fresh forage with enzymes at ensiling; $\mathrm{E}$ enzymes applied onto silage (10 L t ${ }^{-1}$ wet silage) 30 minutes before feeding (direct-fed). Five ruminally cannulated Nellore beef steers were randomly assigned to a 5 x 5 Latin square design. The ruminal passage rate of solid $\left(2.23 \%\right.$ hour $\left.^{-1}\right)$ and liquid $(4.83 \%$ hour $^{-1}$ ) phases were similar for all treatments. The animal ingestive behavior measured as total time (minutes day ${ }^{-1}$ ) and rate (minutes $\mathrm{DM} \mathrm{kg}^{-1}$ ) was not changed across silages DM concentration, averaging DM eating (247; 24), DM ruminating (426; 43) and DM chewing (673; 67), respectively. The molar concentration (109.62 mM) of total volatile fatty acids (VFA) and ammonia-N (5.6 $\mathrm{mg} \mathrm{dL}^{-1}$ ) observed in ruminal fluid were similar across silages diets. According to the results it may be concluded that wilting Tanzania grass or the application of fibrolytic enzymes did not improve significantly either the animal ingestive behavior, ruminal parameters or the nutrient digestibilty. 


\section{INTRODUÇÃO}

A fermentação da forragem é um processo dinâmico que pode ser alterado por diversos fatores. Dentre eles, destaca-se a composição química da espécie de forragem a ser ensilada, principalmente o teor de umidade associado ao teor de carboidratos solúveis que influenciam a fermentação de plantas forrageiras de clima tropical. Algumas pesquisas têm sido conduzidas com o intuito de melhorar a qualidade da silagem através da utilização de aditivos estimulantes de fermentação.

O processo de conservação inicia-se logo após o corte da forragem com a oxidação de açúcares, mediante a respiração celular, atividade de enzimas oxidativas e microrganismos aeróbios. Nesse processo inicial, as enzimas da forragem hidrolisam o amido e a hemicelulose em monossacarídeos que podem ser utilizados na fermentação lática. Os microrganismos presentes convertem os carboidratos solúveis da planta em dióxido de carbono e água, gerando calor. Esse processo aeróbio se estende até que todo o oxigênio ou carboidrato solúvel seja exaurido. Em seguida, é iniciada a fase de fermentação anaeróbia, com a produção de ácidos graxos voláteis, etanol e dióxido de carbono pelas enterobactérias heterofermentativas. Esses microrganismos tornam o ambiente adequado ao desenvolvimento de bactérias láticas homofermentativas, devido à redução de $\mathrm{pH}$. Na fase subseqüente, ocorre aumento da população de bactérias láticas, que fermentam os carboidratos solúveis em ácido lático e ácido graxo, sendo este predominante nas silagens de boa qualidade.

A qualidade fermentativa das silagens pode ser estimada por meio da concentração de ácidos orgânicos, do nitrogênio amoniacal e, até certo ponto, do $\mathrm{pH}$. Uma boa fermentação é caracterizada por bactérias desejáveis (Lactobacillus sp.), que 
são estimuladas a converter os açúcares presentes na forragem em ácido lático. Quando em fermentação lática, pode haver fermentação butírica, deaminação das proteínas e dos aminoácidos por bactérias clostrídicas. Esse processo é considerado indesejável para obtenção de silagens de boa qualidade.

O valor nutritivo da silagem depende da composição química da forragem, do processo fermentativo e do processamento do material a ser ensilado. Assim, nas silagens com bom valor nutritivo, é possível observar melhorias na utilização do alimento pelos animais.

A adição de enzimas fibrolíticas na nutrição de ruminantes tem sido proposta como uma estratégia para incrementar a disponibilidade do substrato e contribuir de forma efetiva para o aumento da fermentação lática da silagem, bem como aumentar seu valor nutritivo. Por isso, é um procedimento que poderia ser utilizado para disponibilizar carboidratos solúveis tanto para o processo de ensilagem como para a fermentação ruminal. Recentemente, essas preparações têm recebido considerável atenção, apresentando resultados satisfatórios no desempenho de animais.

Efeitos como aumentos nas degradabilidades da matéria seca e da fibra em detergente neutro, na produção e no teor de gordura do leite, no ganho de peso em bovinos, assim como a redução da fração fibrosa em silagens, são extensivamente documentados em experimentos com enzimas fibrolíticas. Contudo, sua eficiência pode ser alterada em decorrência de diversos fatores, como tipo de plantas forrageiras, teor de matéria seca, associação a outros aditivos ou formas de aplicação.

Apesar dos consideráveis avanços na aplicação de enzimas na alimentação de ruminantes, alguns obstáculos necessitam ser transpostos, como o entendimento do modo de ação e aplicação dessas enzimas. A ênfase deste trabalho foi avaliar práticas de manejo da ensilagem do capim Tanzânia, como o emurchecimento, a alteração do tamanho médio de partículas, e suas possíveis interações com a aplicação do complexo enzimático, o efeito das enzimas fibrolíticas na ensilagem e em rações para ruminantes, bem como na degradação ruminal e no comportamento ingestivo de bovinos.

Para isso, foram realizados dois ensaios, discutidos separadamente em capítulos. No primeiro, os principais objetivos foram determinar se o tamanho de 
partícula, o emurchecimento e o uso de enzimas fibrolíticas, ou inoculante bacteriano, na ensilagem, alterariam a eficiência do processo de ensilagem, as características de fermentação, a composição química, a estabilidade aeróbia e as perdas por efluente e gases. No segundo ensaio com animais, o objetivo foi avaliar se o emurchecimento do capim Tanzânia e o uso de enzimas fibrolíticas, sob diferentes formas de aplicação, poderiam influenciar os parâmetros ruminais, a digestão de nutrientes e o comportamento ingestivo em novilhos de corte. 


\section{REVISÃO DE LITERATURA}

\subsection{Processo fermentativo, valor nutritivo da silagem e uso de aditivos}

Segundo Stefanie et al. (2000), a ensilagem é um método de preservação de forragem por meio de fermentação preferencialmente lática, sob condições de anaerobiose. Portanto, num processo adequado de ensilagem é necessário que se estabeleça uma rápida condição anaeróbia dentro do silo, através da picagem da forragem a um tamanho de partícula apropriado e homogêneo, visando a compactação satisfatória e expulsão do ar. Adicionalmente, é importante que haja o controle das atividades microbianas, por meio de rápida acidificação da silagem com produtos da fermentação (Kung Junior, 2000; McDonald, 1981).

Outro fator importante a ser considerado é a inibição do crescimento das bactérias produtoras de ácido butírico. Estas bactérias estão presentes na forragem colhida e começam a multiplicar-se assim que as condições do silo tornam-se anaeróbias, sendo prejudiciais na conservação da forragem, pois produzem ácido butírico e degradam aminoácidos em compostos de baixo valor nutricional (McDonald et al., 1991). As enterobactérias, anaeróbias facultativas, fermentam açúcares em ácido acético e também têm a habilidade de degradar aminoácidos, porém seu crescimento é inibido pela queda do pH decorrente da fermentação lática (Woolford, 1984).

Durante a primeira fase da fermentação, pode haver intensa degradação de proteína, elevando a quantidade de peptídeos, aminoácidos, amônia e aminas na silagem. A maioria das enzimas vegetais que realizam proteólise é ativa somente em $\mathrm{pH}$ superior a 5; portanto, uma rápida acidificação provocará a desnaturação destas enzimas, minimizando perdas de proteína e melhorando a aceitação da silagem pelos 
animais (Vilela, 1998).

As silagens de gramíneas são consideradas de qualidade satisfatória se apresentarem $\mathrm{pH}$ inferiores a 4,2, associadas a concentrações de 4 a $6 \%$ de ácido lático na matéria seca (MS), ácido butírico inferior a $0,2 \%$ na MS e nitrogênio amoniacal (N$\mathrm{NH}^{3}$ ) inferior, ou igual, a $11-12 \%$ do nitrogênio $(\mathrm{N})$ total. Pequenas quantidades de acetato e propionato também estão presentes nessas silagens. Os valores de carboidratos solúveis tornam-se baixos após a fermentação, sendo inferiores a 2\% na MS (Castro, 2002; Mahanna, 1993).

O valor nutritivo das plantas forrageiras é determinado pela sua composição química, principalmente pelos teores de proteína bruta $(\mathrm{PB})$ e de fibra em detergente ácido (FDA), responsáveis diretos pela digestibilidade da matéria seca (Nussio et al., 2002). Além disso, a lignina exerce grande influência sobre a taxa de degradação e a degradabilidade efetiva da parede celular dos alimentos volumosos, sendo um fator determinante do conteúdo de energia digestível das plantas forrageiras (Van Soest, 1994).

As gramíneas tropicais apresentam baixo teor de carboidratos solúveis, e as maiores mudanças que ocorrem na composição química das forrageiras são aquelas decorrentes da maturidade da planta (Balsalobre et al., 2001). O desenvolvimento das plantas forrageiras resulta em alterações em nível celular como conseqüência do aumento da concentração de parede celular, levando à diluição do conteúdo celular e provocando diminuição na disponibilidade de substratos prontamente fermentescíveis. Além desse aspecto, têm-se alterações nos tecidos com a diminuição da relação folha/haste, a produção dos componentes potencialmente digestíveis tende a decrescer; a proporção de lignina, celulose e hemicelulose e de outras frações indigestíveis se eleva, resultando em menor digestibilidade. Conseqüentemente, o produto obtido no processo de ensilagem também será de menor valor nutritivo se for colhido tardiamente. Por outro lado, quando são ensiladas em estágio inicial de crescimento vegetativo, o alto teor de umidade e a alta capacidade-tampão podem influenciar negativamente o processo fermentativo, impedindo o rápido decréscimo do $\mathrm{pH}$ até níveis adequados e prejudicando a qualidade do produto conservado (Lavezzo, 1985). 
Atualmente, uma grande diversidade de aditivos está sendo recomendada para melhorar a qualidade da silagem. Entre os produtos enzimáticos, existem diferenças entre as propriedades, a especificidade da planta forrageira, o manuseio e as formas de aplicação. Estes fatores, juntamente com o custo e a viabilidade do uso, irão determinar, segundo Stefanie et al. (2000), a escolha do aditivo mais adequado a ser utilizado na ensilagem. Os aditivos podem ser divididos em dois grandes grupos, de acordo com seu papel no processo de fermentação: estimulantes da fermentação, que atuam favorecendo o crescimento de bactérias láticas e a produção de ácidos orgânicos, reduzindo o $\mathrm{pH}$; e os inibidores de fermentação, que agem sobre o crescimento de fungos e bactérias, responsáveis pela deterioração aeróbia, além de restringirem a ação proteolítica das plantas (Pitt, 1990).

\subsection{Caracterização das enzimas}

Aditivos enzimáticos podem conter um único grupo de enzimas, uma combinação de vários grupos de enzimas ou combinações de enzimas e inoculante bacteriano. A maior parte dos aditivos comerciais para ensilagem, em geral, contém enzimas fibrolíticas combinadas a bactérias homoláticas. Segundo Pitt (1990), existem vários tipos de enzimas disponíveis para serem usadas como aditivos em silagens: as hemicelulases, que degradam a hemicelulose em pentoses, disponibilizando açúcares para serem utilizados no processo de fermentação, sendo consideradas responsáveis pela redução do teor de FDN e pela degradação da hemicelulose; as celulases, que degradam a celulose em glicose para ser usada durante a fermentação, responsáveis pela redução dos teores de FDN e FDA; as amilases, que degradam o amido; as pectinases, que degradam as pectinas; e, finalmente, as proteases, que degradam as proteínas da forragem em formas solúveis, como aminas e amônias, portanto, não sendo recomendada sua presença em aditivos enzimáticos.

A maioria das enzimas usadas como aditivos é subproduto ou extrato fermentativo microbiano (Bacillus sp.) ou fúngico (Trichoderma sp. e Aspergillus sp.) que possui um ou vários tipos de atividade enzimática. Desse modo, uma preparação enzimática com atividade predominante de xilanase poderá, também, conter outras 
atividades, como protease, celulase, pectinase e beta-glucanase (Rode \& Beauchemin, 1999), o que pode acarretar no comprometimento da utilização desses substratos, caso a atividade enzimática não esteja adequadamente estabelecida.

Existem dois motivos principais na utilização de enzimas fibrolíticas como aditivos estimulantes de fermentação em silagens de capim tropicais. Primeiro, porque estas enzimas poderiam participar na degradação da parede celular (celulose e hemicelulose), disponibilizando os açúcares solúveis que poderiam ser fermentados pelas bactérias láticas homofermentativas, reduzindo rapidamente o $\mathrm{pH}$. O rápido declínio do $\mathrm{pH}$ poderia limitar também a degradação e deaminação protéica e reduzir a produção de amônia. Conseqüentemente, ocorreria um estímulo na fermentação da silagem, devido ao aumento da concentração do ácido lático e da relação dos ácidos lático:acético, além da redução na perda de matéria seca. Segundo, a degradação parcial da parede celular poderia aumentar a taxa de digestibilidade da matéria orgânica da forragem (McDonald et al., 1991; Henderson, 1993; Kung Junior, 1997). Assim, para a realização desses processos, é importante que a hidrólise da celulose coincida com o crescimento inicial das bactérias láticas e que haja degradação dos componentes da parede celular para melhorar a digestibilidade (Kung Junior, 1997).

Para melhor entendimento do papel das enzimas fibrolíticas na degradação da parede celular, faz-se necessário destacar alguns dos principais componentes da parede, como a celulose e hemicelulose. A celulose caracteriza-se por possuir alto grau de polimerização (composta de polímeros de glicose $\beta(1-4)$ ), formando uma longa cadeia linear, e por apresentar-se principalmente na forma cristalina. Seu grau de cristalização na parede celular varia muito, apresentando valores abaixo de $20 \%$ na parede primária e acima de 70\% na secundária. A fração hemicelulose é composta, principalmente, de ligações xiloglucanas $\beta(1-4)$ com quantidades variadas de arabinose, galactose e ácido urônico, presentes nas paredes primária e secundária da parede celular da planta.

Segundo Ferreira et al. (1999), existem basicamente três tipos de enzimas que participam da degradação da celulose: endo- $\beta$-(1-4) glucanases, que, de forma aleatória, clivam as ligações glicosídicas internas deste polímero em oligossacarídeos; exo- $\beta$ glucanases, também referidas como celobiohidrolases, que, seqüencialmente, removem 
dímeros de celobiose de uma das terminações da celulose; e as $\beta-(1-4)$ glucosidases, responsáveis pela hidrólise da celobiose em glicose. Enquanto as endoglucanases agem somente nas regiões não-cristalinas da celulose (também designada de regiões amorfas), as celobiohidrolases atuam sobre suas terminações não-redutoras, independentemente da forma física apresentada por este polímero. A degradação das hemiceluloses é mais complexa, já que a cadeia polimérica se encontra ligada a numerosas cadeias laterais (Fontes et al., 1996).

\subsection{Fatores que devem ser considerados na avaliação da ação das enzimas fibrolíticas no processo de conservação da forragem}

\subsubsection{Tamanho de partícula}

Em geral, os estudos sobre a redução do tamanho de partícula no processo de conservação de forragens concentram-se em dois pontos importantes: melhoria da qualidade de fermentação da silagem, ocasionada pela adequada compactação; e aumento de perdas por efluente em silagens provenientes de plantas colhidas com a umidade original.

Dessa forma, a redução do tamanho de partícula da forragem pode ser uma alternativa para melhorar a qualidade da fermentação da silagem, por promover redução da fermentação butírica, maior compactação e queda mais rápida de pH. À medida que se aumenta a intensidade da picagem da forragem para a ensilagem, ocorrem aumentos significativos na população de bactérias láticas (Pereira \& Reis, 2002). Contudo, em silagens sem emurchecimento, o menor tamanho pode provocar maior perda por efluente (Aguiar et al., 2000; Igarasi, 2002).

Gordon et al. (1958) verificaram maior produção de efluente em alfafa (Medicago sativa L.) que sofreu maceração após picagem em tamanhos de partículas de $0,8 \mathrm{~cm}$ de comprimento, quando comparada àquelas picadas a $7 \mathrm{~cm}$. Em silagens de capim de Tanzânia, tamanhos menores de partícula apresentaram maior necessidade de adição de polpa cítrica para minimizar as perdas de efluente (Aguiar et al., 2000).

O processamento físico através de picagem e esmagamento pode melhorar o 
processo de conservação da silagem, permitindo maior acomodação do material dentro do silo e diminuindo a fase aeróbia da ensilagem. Segundo Lavezzo (1985), o corte da forragem visando a ensilagem deveria apresentar tamanhos de partículas de 3 a $5 \mathrm{~cm}$, a fim de permitir maior compactação e, por conseguinte, garantir um ambiente anaeróbio mais rapidamente.

Aguiar et al. (2001) constataram que a redução do tamanho de partícula do capim Tanzânia foi eficiente em assegurar menor conversão de outras frações nitrogenadas em nitrogênio não-protéico. Segundo os autores, isso pode ocorrer, pois a redução no tamanho de partícula proporcionaria maior compactação no silo, diminuindo o processo de respiração, a temperatura e a atividade proteolítica, devido à rápida redução de $\mathrm{pH}$.

A redução do tamanho de partícula da forragem cria algumas controvérsias, pois, ao mesmo tempo em que se destacam as vantagens, por aumentar a compactação e melhorar as propriedades fermentativas, não mostra benefícios em aumentar as perdas ocorridas na forma de efluente, em razão do maior rompimento da parede celular e do extravasamento exagerado do conteúdo celular. No entanto, ainda não está estabelecida a relação entre a intensidade do processamento físico e o extravasamento de suco celular, havendo alguns questionamentos, visto que nem sempre o corte da forragem promove a liberação do conteúdo celular, podendo haver dilaceração e esmagamento, em vez de corte preciso. Assim, o tamanho médio de partículas não estaria necessariamente relacionado com o aumento da carga de efluente na forragem ensilada (Woolford, 1984).

Conforme Kraus et al. (1997), há muitos métodos que foram desenvolvidos para avaliar a quantidade de constituintes lixiviados das células de forragem que foram rompidas, porém um dos mais precisos seria aquele baseado na mensuração da condutividade elétrica. Os autores observaram que a magnitude da condutividade elétrica é proporcional à quantidade de eletrólitos (íons) na solução, e esta depende principalmente da extensão da ruptura celular. Em vista disso, a condutividade elétrica se apresenta como interessante e poderosa ferramenta para a avaliação do dano físico causado às partículas durante a picagem. 
Do ponto de vista nutricional, é importante o efeito do tamanho de partícula sobre os parâmetros ruminais e o desempenho de animais. Yang et al. (2001b), avaliando os efeitos do tamanho de partícula da silagem de alfafa $(7,59$ e $6,08 \mathrm{~mm})$ sobre o $\mathrm{pH}$ e digestibilidade ruminal em vacas leiteiras, não verificaram efeito algum do comprimento de partícula sobre $\mathrm{pH}$, digestibilidade ruminal e produção de leite.

Em outro experimento, em 2002, estes pesquisadores avaliaram o tamanho de partícula de fenos e silagens de alfafa. As dietas submetidas à moagem ou picagem consistiram em $60 \%$ de concentrado e $40 \%$ de forragem; na fração de volumoso havia uma proporção estabelecida de 50:50 ou 25:75 de silagem e feno de alfafa. A variação do tamanho de partícula não alterou o consumo, porém o maior tamanho de partícula da forragem aumentou a síntese protéica e a eficiência microbiana, a digestibilidade de fibra e $\mathrm{N}$ no trato digestivo total, assim como a digestibilidade da matéria orgânica, amido e FDA no intestino. Estes resultados positivos em relação ao maior tamanho de partícula podem estar associados ao aumento do $\mathrm{pH}$ ruminal, da razão acetato:propionato e do tempo de retenção.

\subsubsection{Produção de efluente}

Segundo Woolford (1984), o efluente representa a porção líquida da forragem drenada após a ensilagem, sendo responsável por perdas de 5 a 10\% de MS na silagem (McDonald, 1981).

O volume do efluente produzido no silo é influenciado, principalmente, pelo conteúdo de matéria seca, grau de compactação do material ensilado, tipo de silo, prétratamento mecânico da silagem, espécie de forragem e uso de aditivos na ensilagem como inoculantes bacterianos e enzimáticos (Loures, 2000). Vários estudos têm mostrado correlação negativa entre conteúdo de matéria seca da forragem e quantidade de efluente produzida (Miller \& Clifton, 1965; Castle \& Watson, 1973; Woolford, 1984; Jones \& Jones, 1995) e a importância do processamento mecânico da forragem sobre sua produção (Gordon et al., 1958; McDonald et al., 1991).

Embora todos os fatores citados sejam de suma importância na avaliação da produção de efluente, dar-se-á maior destaque ao uso de aditivos biológicos. A aplicação 
de aditivos enzimáticos e sua associação com inoculantes bacterianos apresentam alguns resultados contraditórios, apesar de se verificar tendência geral de aumento na produção de efluente. Segundo Treacher \& Hunt (1996), o uso de aditivos enzimáticos em materiais com elevada digestibilidade e com baixo conteúdo de matéria seca tem sido considerado o principal fator responsável pelo excessivo aumento na produção de efluente. Resultados semelhantes foram observados em alguns trabalhos de revisão realizados por Jones \& Jones (1995) e Jaster (1995), em que o uso de enzimas que degradam a parede celular aumentou a produção de efluente, especialmente em condições de baixo conteúdo de MS na forragem. Haigh (1999) observou que a adição de inoculante, composto basicamente de Lactobacillus plantarum, Pediococcus spp. e de enzimas, em silagens de azevém-perene (Lolium multiflorum Lam.) mais trevo-branco (Trifolium repens L.) e silagens de azevém-perene apresentou pouco efeito sobre a produção de efluente. O mesmo foi observado por Igarasi (2002), que não constatou efeito significativo sobre a produção de efluente em silagem de capim Tanzânia tratada com inoculante bacteriano.

A produção de efluente proveniente de silagens pode ser considerada uma das fontes mais agravantes de poluição ambiental em diversos países da Europa, apesar de ser muito pouco discutida no Brasil. A avaliação do grau de poluição é feita por meio das análises de demanda bioquímica de oxigênio (DBO) e demanda química de oxigênio (DQO). A demanda bioquímica de oxigênio é uma metodologia importante na análise do conteúdo de matéria orgânica decomponível em esgotos domésticos. É definida como a quantidade de oxigênio, expressa em $\mathrm{mg} \mathrm{L}^{-1}$, necessária para estabilizar a matéria orgânica, por microrganismos aeróbios, num período de cinco dias, a $20^{\circ} \mathrm{C}$ (Silva, 1977). Se o grau de poluição for elevado, o material a ser analisado deverá conter maior teor de matéria orgânica biodegradável e as bactérias necessitarão de grande quantidade de oxigênio para estabilizar esta matéria orgânica. Por outro lado, sendo menor o conteúdo de matéria orgânica, as bactérias terão necessidade de menor quantidade de oxigênio e, então, a DBO será baixa. A DQO é definida como a quantidade de oxigênio expressa em $\mathrm{mg} \mathrm{L}^{-1}$ necessária para estabilizar a matéria orgânica, através da utilização de um forte oxidante, como o dicromato de potássio. 
A composição do efluente das silagens apresenta muitas variações, sendo observados valores de DBO de 40.000 a $90.000 \mathrm{mg} \mathrm{L}^{-1}$; de $\mathrm{MS}$ ou sólidos totais, de 27.000 a $92.000 \mathrm{mg} \mathrm{L}^{-1}$; de $\mathrm{pH}$, de 4,2 a 4,7; e de $\mathrm{N}$ total, de 3.670 a $4.120 \mathrm{mg} \mathrm{L}^{-1}$ (Galanos et al., 1995; McDonald, 1981). Mais recentemente, Loures (2000) verificou, em efluente proveniente de silagens de capim-elefante, valores médios de $14.597 \mathrm{mg} \mathrm{L}^{-1}$, $31.138 \mathrm{mg} \mathrm{L}^{-1}, 31.730 \mathrm{mg} \mathrm{L}^{-1}$ e 4,3 para DBO, DQO, sólidos totais e $\mathrm{pH}$, respectivamente, e destacou que, apesar de o valor para a DBO encontrar-se abaixo dos verificados na literatura, essa quantidade ainda é considerada muito alta e com grande potencial poluidor.

\subsubsection{Emurchecimento}

O emurchecimento exerce um efeito de concentração de substratos fermentescíveis que, juntamente com o aumento do potencial osmótico, dificulta o desenvolvimento de bactérias indesejáveis, principalmente as do gênero Clostridium sp; e permite a dominância de bactérias homofermentativas láticas, o que possibilita rápido declínio do pH e menor extensão da fermentação (Woolford, 1984). Contudo, a extensão desse processo poderá afetar a qualidade de fermentação da silagem, caso o emurchecimento se estenda por muitos dias, por haver consumo dos carboidratos solúveis presentes na forragem, redução do teor de $\mathrm{N}$ protéico e aumento da deaminação de aminoácidos (Henderson, 1993).

Tosi et al. (2002) verificaram, em experimento com silagem de capim-elefante (Pennisetum purpureum Schum.), que o emurchecimento aplicado durante 24 horas foi prejudicial à ensilagem, por reduzir a quantidade de carboidratos solúveis da massa a ser ensilada; já o emurchecimento aplicado durante 12 horas revelou-se mais apropriado como pré-tratamento para a ensilagem.

Em gramíneas e leguminosas com teores mais elevados de matéria seca e baixa concentração de açúcares solúveis, a adição de enzimas fibrolíticas pode apresentar resultados satisfatórios, devido à liberação de açúcares provenientes da hidrólise da parede celular, fornecendo substrato adicional para produção de ácido lático pelas bactérias (Muck \& Kung Junior, 1997; Beauchemin \& Rode, 1996). Além disso, sua 
aplicação em forragens com maior teor de matéria seca favorece a formação de um complexo enzima-forragem bastante estável, que aumenta a eficiência das enzimas fibrolíticas. A formação desse complexo ocorre rapidamente (em questão de horas) e essa estabilidade é mantida por várias semanas, como pode ser verificado em condições laboratoriais (Rode \& Beauchemin, 1999).

Feng et al. (1992), avaliando cinco teores de umidade em amostras de gramíneas e o efeito de aditivos enzimáticos sobre estas na degradação in situ e in vitro, observaram que o emurchecimento em gramíneas de inverno tratadas com enzimas fibrolíticas aumentou a degradabilidade ruminal e in vitro da fibra; todavia, a aplicação das enzimas em forragens úmidas proporcionou redução de degradabilidade da gramínea.

Rangrab et al. (2002), em estudo com alfafa submetida à ação de aditivos biológicos e ao efeito de emurchecimento, por 20 horas, constataram que o emurchecimento preservou o $\mathrm{N}$ protéico, bem como proporcionou menor $\mathrm{pH}$ e economia de carboidratos solúveis residuais. Além disso, a ação dos aditivos em alfafa não emurchecida proporcionou valores estatisticamente mais baixos de $\mathrm{pH}$ e $\mathrm{N}-\mathrm{NH}^{3}$ nos tratamentos com enzimas e lactobacilos mais enzimas. Em forragens emurchecidas e não emurchecidas, houve diminuição dos níveis de nitrogênio insolúvel em detergente neutro (NIDN) para o tratamento com enzimas, bem como redução do teor de FDN da forragem do tratamento contendo lactobacilos mais enzimas. Segundo estes autores, isso parece indicar que as enzimas presentes nestes produtos apresentaram sítios de ação diferenciados na degradação celular.

\subsubsection{Fermentação e fração fibrosa}

A aplicação de aditivos enzimáticos tem sido bastante efetiva na redução do conteúdo da fração fibrosa de gramíneas. A melhoria na fermentação da silagem, por favorecer a rápida queda do $\mathrm{pH}$ e reduzir o $\mathrm{N}-\mathrm{NH}^{3}$ e o conteúdo de fibra, é mais evidente em gramíneas mais novas do que em forragens mais maduras, onde a hidrólise da parede celular é mais difícil, em razão do aumento do grau de lignificação da forragem (Sheperd \& Kung Junior, 1996; Nadeau et al., 2000). Recentemente, o pré-tratamento de 
palhadas de trigo (Trificum aestivum L.) com hidróxido de sódio associado a enzimas fibrolíticas exógenas (xilanase, $\beta$-glucanase e carboximetilcelulase) incrementou a eficácia da ação enzimática, por quebrar as ligações esterificadas e liberar compostos fenólicos, modificando, assim, a região cristalina da celulose (Wang et al., 2004).

Os resultados consistentes obtidos em relação aos efeitos dos aditivos enzimáticos em silagens têm sido atribuídos à redução dos conteúdos de FDN e FDA (Pritchard et al., 1996), refletindo, conseqüentemente, em melhoria na qualidade de fermentação e no desempenho animal e redução nas perdas de MS. A celulase atuaria aumentando a degradação do tecido de parênquima da alfafa e Phleum pratens L., sendo considerada eficaz na fermentação da silagem (Aisan et al., 1997). O mesmo pôde ser constatado por Tamada et al. (1999) em silagens de capim-elefante: a celulase melhorou a qualidade de fermentação da silagem.

Em silagens de gramíneas tropicais, cujo teor de carboidratos solúveis é limitante, a adição enzimática pode promover fermentação adequada, por aumentar o teor de ácido lático, reduzindo o $\mathrm{pH}$ e inibindo o crescimento de bactérias indesejáveis. Quando o teor de carboidratos solúveis passa a não ser limitante, como em silagens de milho (Zea mays L.), o efeito de aditivos enzimáticos pode ter impacto negativo, por estimular a fermentação por leveduras. Colombatto et al. (1999) verificaram que preparações comerciais enzimáticas, contendo tanto xilanase quanto celulase, foram efetivas na redução da parede celular em silagens de milho. Em um outro trabalho com silagens de milho, os preparados enzimáticos, apesar de reduzirem o conteúdo de fibra, não melhoraram a fermentação da silagem (Sheperd \& Kung Junior, 1996). No entanto, recentes estudos indicam resultados promissores da adição de enzimas fibrolíticas na melhoria da fermentação e do valor nutritivo de silagens de milho (Colombatto et al. 2004a, 2004b, 2004c).

Considerando-se que a baixa concentração de carboidratos prontamente fermentescíveis representa fator limitante para o desenvolvimento de bactérias homoláticas, presentes nos inoculantes para silagens, a associação de inoculantes e enzimas poderia promover melhor fermentação em forragens que apresentam esse tipo de limitação. Em estudo sobre o uso de inoculante e enzimas fibrolíticas, isolados ou 
associados, nas silagens de capim Tifton 85 (Cynodon sp.) e Coastal Bermuda (Cynodon dactylon L.) não foi verificado efeito dos tratamentos impostos sobre o desaparecimento in vitro e in situ da MS e da FDN ou sobre a concentração de fibra (Mandebvu et al., 1997a, 1997b). Entretanto, Mandebvu et al. (1998,1999), em avaliações semelhantes, observaram que a digestibilidade da fibra foi maior em silagens de capim Coastal Bermuda tratadas com inoculante bacteriano do que naquelas tratadas com enzimas fibrolíticas.

Nadeau et al. (2000) observaram, em silagens de Dactylis glomerata L., que a melhoria na qualidade de fermentação deve-se mais à adição do inoculante bacteriano do que à adição de enzima fibrolítica (celulase). Contudo, em silagens de alfafa, a adição exclusiva de celulase proporcionou não só uma fermentação de boa qualidade, mas também resultou em melhor qualidade das características de fermentação com a adição do inoculante. Isso indica que o efeito positivo obtido com a associação de enzimas fibrolíticas e inoculante é específico quanto ao tipo de forragem utilizada, sendo diferenciado entre gramíneas e leguminosas. Neste caso, é importante destacar que as gramíneas apresentam maior proporção de hemicelulose na parede celular do que as leguminosas (Buxton \& Mertens, 1995). Além disso, nesse mesmo experimento, os referidos autores constataram que o decréscimo de FDN e o aumento na concentração de açúcar solúvel não aumentaram a digestibilidade in vitro da MS das silagens tratadas com celulase. A possível explicação para tal resultado de digestibilidade seria o fato de a silagem utilizada pelo animal ser constituída de parede celular remanescente menos digestível, decorrente da hidrólise pela celulase.

Em forragens de Digitaria eriantha, o efeito da adição de enzimas fibrolíticas (celulase, hemicelulase), associado ao inoculante (Lactobacillus plantarum, Steptococus faecium e Pediococcus acidilactici), sobre a dinâmica de fermentação promoveu rápida redução de $\mathrm{pH}$, teores elevados de ácido lático, menor proteólise e menor ocorrência de enterobactérias. Houve, ainda, aumento no consumo e na digestibilidade da matéria orgânica (Meeske et al., 1999).

No entanto, em azevém (Lolium multiflorum) com 35\% de MS, a adição de enzimas (celulase) e inoculantes bacterianos na ensilagem não resultou em alteração nos 
valores de FDN, FDA, pH, ácido lático, ácido acético e nitrogênio amoniacal, em relação às silagens sem aditivos (Kuss, 2001).

\subsection{Efeito das enzimas fibrolíticas na digestão de nutrientes e no desempenho de animais}

Os mecanismos pelos quais as enzimas fibrolíticas podem melhorar o desempenho de animais permanecem pouco explorados, apesar de ter recebido maior enfoque nos últimos anos. Parte dessa contribuição vem de resultados de pesquisas que observaram o aumento da degradação de fibra pelos microrganismos ruminais (Hristov et al., 1997; Feng et al., 1992; Lewis et al., 1996).

Segundo Nsereko et al. (2002), esse aumento da degradabilidade da fibra pode ser atribuído ao crescimento da população de microrganismos, que contribuiria para a maior degradação da fibra no rúmen. A provável explicação para este aumento da população seria a remoção das barreiras estruturais da parede celular pela ação das enzimas fibrolíticas (xilanase e celulase), o que tornaria mais fácil a colonização da fibra pelas bactérias ruminais. Adicionalmente, as preparações enzimáticas poderiam agir como defaunadores, permitindo que a população bacteriana estivesse menos susceptível à predação de protozoários. Wallace et al. (2001) constataram, igualmente, que o efeito adaptativo da população microbiana à ação prolongada da enzima no alimento causou maior degradação da fibra e alteração na dinâmica da população microbiana.

Em revisão de literatura, entre os anos de 1990 e 1995, Kung Junior \& Muck (1997) verificaram que os efeitos das enzimas fibrolíticas no desempenho de animais, em $21 \%$ dos trabalhos $(n=29)$, resultaram em incrementos no consumo de MS, em 40\% dos trabalhos $(n=10)$, em incrementos no ganho de peso; em 33\%, na produção de leite $(n=12)$ e em $27 \%$, na eficiência alimentar $(n=11)$. Contudo, em outros trabalhos de revisão não foram verificados tais incrementos no desempenho de animais, principalmente em relação à digestibilidade de MS (McDonald, 1981; Fahey et al., 1994;

Berger \& Fahey Jr, 1994). De acordo com os trabalhos de Muck \& Kung Junior (1997) e Kung Junior et al. (2000a), a solubilização da porção mais digestível dos carboidratos da parede celular pelas enzimas, deixando a fração menos degradável para ser digerida pelo 
animal, seria o fator responsável pelas respostas negativas no desempenho animal.

Experimentos com diferentes combinações de concentração, dose e tipo de enzimas apresentaram aumentos significativos no desempenho de ruminantes (Nussio et al., 1997; Schingoethe et al., 1999; Lewis et al., 1999; Beauchemin et al., 1998). A adição enzimática em dietas de alfafa e azevém para cordeiros melhorou mais acentuadamente a digestibilidade aparente da MS, PB, FDN da alfafa do que do azevém, enfatizando assim que a magnitude do efeito de enzimas fibrolíticas também irá depender do tipo de forragem utilizada (Pinos et al., 2000). A proporção da dieta em que as enzimas fibrolíticas são aplicadas também pode afetar o desempenho dos animais; segundo Bowman et al. (2002), aplicando as enzimas no concentrado, que representava $45 \%$ da ração de mistura total, no suplemento, que representava $2 \%$ da ração, e no premix, que representava $0,2 \%$ da ração; os melhores resultados na produção de leite foram observados quando as enzimas foram aplicadas na maior porção da dieta.

De acordo com Cheng et al. (1995), os aumentos da digestibilidade da fibra devido ao tratamento enzimático estão relacionados à melhoria da colonização das partículas do alimento pelos microrganismos ruminais e a um possível estímulo da atividade enzimática endógena causado por enzimas exógenas. Morgavi et al. (2000) observaram que o sinergismo entre enzimas endógenas e exógenas pode contribuir parcialmente para o aumento da digestão da fibra, observado em dietas suplementadas com enzimas fibrolíticas fornecidas para vacas leiteiras.

Hristov et al. (1997) constataram que uma significante proporção de enzimas fibrolíticas escapa da digestão ruminal e permanece ativa no intestino grosso, sugerindo, portanto, que as enzimas exógenas podem alterar o mecanismo de absorção de nutrientes no intestino grosso. Além disso, existem fortes evidências de que a adição de enzimas fibrolíticas poderia alterar a digestão da fibra do rúmen para o intestino (Sutton et al., 2003).

O método de aplicação das enzimas fibrolíticas nas dietas é um fator decisivo para a ação das enzimas em ruminantes, daí , a necessidade de determinar se as enzimas fibrolíticas são mais efetivas quando adicionadas diretamente na forragem, no concentrado ou na mistura total de ração (Yang et al., 1999). Segundo Yang et al. 
(2001a), as enzimas fibrolíticas, quando aplicadas diretamente no concentrado da dieta para vacas, no início de lactação, proporcionaram aumentos na produção de leite em razão do incremento da digestibilidade de nutriente no trato digestivo total. No entanto, quando estas enzimas eram misturadas diretamente na ração de mistura total, não havia aumento na produção de leite, apesar de aumentar a digestibilidade. Sutton et al. (2003), avaliando diferentes formas de aplicação de enzimas fibrolíticas, pulverizando-as na ração de mistura total (uma hora antes do fornecimento), no concentrado ou através de infusão ruminal, constataram que o melhor tratamento ocorreu quando se aplicava a enzima sobre a mistura total de ração; contudo, os três métodos de aplicação apresentaram resultados semelhantes quanto à fermentação e cinética ruminal.

A aplicação de enzimas à forragem minutos antes de seu fornecimento ao animal possibilita maior flexibilidade no manejo da alimentação, além de reduzir qualquer probabilidade de interação negativa que o processo de conservação possa proporcionar à eficiência do aditivo enzimático. Quando fornecidas dessa maneira, as enzimas fibrolíticas formam ligações com os substratos, que as protegem da degradação ruminal e podem aumentar a digestibilidade da forragem através de diferentes mecanismos, como: hidrólise direta, melhoria da aceitabilidade, alterações na viscosidade intestinal e mudanças do local de digestão. Michal et al. (1996) realizaram a aplicação direta de enzimas fibrolíticas em feno de alfafa, momentos antes de ofertar ao animal, e propuseram, como uma forma viável, a utilização deste método como modo de aplicação. Em trabalho mais recente sobre avaliação do desempenho de vacas holandesas, alimentadas com forragens recebendo aplicação direta de enzimas fibrolíticas imediatamente antes de ofertar ao animal, estes autores verificaram que o consumo, a produção de leite e o ganho de peso não foram alterados em função do tratamento aplicado (Dhiman et al., 2002). Em dietas contendo 55\% de concentrado, $30 \%$ de silagem de milho e $15 \%$ de feno de alfafa, a aplicação de enzimas fibrolíticas (celulase e xilanase) também não se mostrou eficiente no incremento da produção de leite e ingestão de MS em vacas leiteiras (Kung Junior et al., 2002).

Segundo Knowlton et al. (2002), vacas holandesas, em diferentes estágios de lactação, recebendo forragem tratada com enzima fibrolítica minutos antes de seu 
fornecimento, apresentaram maior ganho de peso corporal, porém não houve alteração significativa da digestibilidade aparente ou da excreção de $\mathrm{N}$ e fósforo ou retenção desses nutrientes no tecido corporal. A quantidade de enzimas ativas aplicadas nos alimentos é muito importante para a determinação da eficiência do tratamento. A dificuldade em se mensurar a eficiência de distribuição de pequenas quantidades de preparações enzimáticas, nos alimentos, reflete na grande proporção da razão líquido: sólido usada em experimentos: $0,05 \mathrm{~mL}$ de enzimas diluídas para cada 0,5 gramas de alimento, equivalente a $100 \mathrm{~L}$ tonelada $^{-1}$; esta diluição é muito superior àquela recomendada para aplicação comercial de 1,5 ou 2,0 L tonelada ${ }^{-1}$. Segundo Wallace \& Hartnell (2001), é mais fácil misturar pequenas quantidades da preparação enzimática em condições experimentais do que grandes quantidades, normalmente usadas em fazendas. Os autores sugerem que a efetividade dos aditivos enzimáticos seria dependente de seu local de ação, se a eficiência do aditivo dependesse principalmente do manejo pré-alimentar; dessa maneira, haveria necessidade de uma distribuição homogênea no alimento antes do consumo - caso contrário, se essa eficácia dependesse de parâmetros ruminais, essa distribuição homogênea passaria a não ser crítica, uma vez que as enzimas seriam misturadas no rúmen como parte do processo de digestão.

A análise da literatura indica maior freqüência de trabalhos sobre a utilização das enzimas fibrolíticas para alimentação em animais lactantes do que em bovinos de corte. A combinação de enzimas fibrolíticas (celulase e xilanase) mostrou-se bastante eficiente no incremento do consumo, no ganho de peso diário e na conversão alimentar em gado de corte (Pritchard et al., 1996). Jacobs et al. (1992) constataram, em silagens de azevém-perene, que a adição de enzimas fibrolíticas foi capaz de promover redução do consumo de FDA e FDN, apesar da não-alteração sobre o consumo de matéria orgânica; houve ainda aumento da digestibilidade aparente da matéria orgânica em novilhos em crescimento. Quando as enzimas fibrolíticas foram adicionadas em dietas contendo $80 \%$ de concentrado e $20 \%$ de volumoso não foi observado efeito dos tratamentos no ganho de peso diário, no consumo de MS, na conversão alimentar e nas características de carcaça de novilhos em crescimento e em terminação (Zobell et al., 2000). 
Já Sanchez et al. (1996), avaliando o desempenho de animais lactantes, verificaram aumento na produção de leite, no consumo de MS, e no teor de gordura e proteína do leite; os melhores resultados foram obtidos quando aplicadas em doses médias $\left(2,5 \mathrm{~mL} \mathrm{~kg}^{-1}\right.$ de MS da forragem) da mistura enzimática. Beauchemin et al. (1998) observaram que a adição da mistura enzimática (celulase/xilanase) em volumosos (alfafa) ou concentrados aumentou a digestibilidade do alimento e produção de leite, sendo a resposta do tratamento enzimático mais afetada pela quantidade de complexo enzimático aplicado do que pelo tipo de substrato. Em outros experimentos, verificou-se que a adição de enzimas fibrolíticas no concentrado de vacas no início da lactação foi capaz de promover significativo aumento na produção de leite e digestibilidade de nutrientes, sem, contudo, alterar o consumo (Higginbotham et al., 1994; Yang et al., 1997; Rode et al., 1999). Efeitos positivos também foram verificados por Maki et al. (1998) e Lewis et al. (1996) na fermentação ruminal e digestibilidade.

No entanto, Zheng \& Stokes (1997) não confirmaram incrementos na produção de leite quando adicionaram enzimas fibrolíticas (celulase, celobiase e xilanase) na forragem. Luchini et al. (1997) observaram que a produção de leite em animais alimentados com forragem tratada com enzimas fibrolíticas (celulase/xilanase), minutos antes do trato animal, não foi alterada, entretanto houve incremento do teor de gordura no leite. Nussio et al. (1997) verificaram apenas tendência de efeito positivo no desempenho de vacas leiteiras, em início de lactação, quando receberam feno de alfafa tratado com diferentes doses da combinação enzimática celulase/xilanase. Em outro experimento, Zheng et al. (2000), aplicando enzimas fibrolíticas diretamente sobre a mistura de silagem de milho e feno de alfafa, na proporção de 60:40, constataram que não houve efeito na taxa de consumo dos animais recebendo silagem controle e com enzimas, porém houve aumento de produção de leite nos tratamentos contendo enzimas.

Diante desse contexto, o presente experimento procurou abordar os efeitos desses aditivos e suas formas de aplicação tanto no processo de ensilagem, como na digestão de nutrientes, os parâmetros ruminais e o comportamento ingestivo de bovinos que receberam rações contendo silagens de Tanzânia tratadas com enzimas fibrolíticas. 


\section{CONTROLE DE PERDAS NA ENSILAGEM DE CAPIM TANZÂNIA SOB OS EFEITOS DO TEOR DE MATÉRIA SECA, TAMANHO DE PARTÍCULA E DO USO DE ENZIMAS FIBROLÍTICAS NA PRESENÇA OU NÃO DE INOCULANTE BACTERIANO}

\section{Resumo}

O presente trabalho teve por objetivo avaliar o efeito do emurchecimento, da redução do tamanho das partículas e da adição de enzimas fibrolíticas (associadas ou não ao inoculante bacteriano Lactobacillus plantarum) na fermentação da silagem e nas perdas no processo de conservação em silagem de capim Tanzânia (Panicum maximum, Jacq. cv. Tanzânia). A forragem foi cortada aos 45 dias de crescimento vegetativo e armazenada em silos experimentais $(50 \mathrm{~L})$ durante 136 dias. Durante o período de armazenamento o efluente foi coletado e quantificado no $1^{\circ}, 2^{\underline{o}}, 7^{\circ}, 14^{\stackrel{o}{ }}, 21^{\circ}, 60^{\underline{o}}, 90^{\circ}$ e $136^{\circ}$ dias. A redução do tamanho de partícula não influenciou as perdas totais, embora o tamanho menor tenha contribuído para garantir maior estabilidade aeróbia da silagem. As taxas de recuperação e perdas de MS por efluente e gases foram de 72,5 e $23 \%$ nas silagens não-emurchecidas e de 80,0 e $21 \%$ nas silagens emurchecidas. A adição de enzimas fibrolíticas associadas ou não ao inoculante bacteriano promoveu redução da fração fibrosa (FDN, FDA, celulose, hemicelulose), a qual foi mais acentuada nas silagens emurchecidas. Contudo, não houve aumento da digestibilidade in vitro da MS com adição de enzimas fibrolíticas. Os valores médios de DBO (11.289 mg L $\left.{ }^{-1}\right)$, DQO (36.279 $\left.\mathrm{mg} \mathrm{L}^{-1}\right)$, DQO/DBO $(3,35), \mathrm{pH}(4,9)$, sólidos totais $\left(34.395 \mathrm{mg} \mathrm{L}^{-1}\right)$ e 
sólidos totais fixos $\left(16.533 \mathrm{mg} \mathrm{L}^{-1}\right)$ foram observados no efluente das silagens com umidade original. $\mathrm{O}$ aumento do período de armazenamento incrementou significativamente o potencial poluidor do efluente.

\section{CONTROL OF ENSILING LOSSES IN TANZANIA GRASS AFFECTED BY DRY MATTER CONTENT, PARTICLE SIZE AND MICROBIAL/ENZYMATIC ADDITIVE}

\section{Summary}

The present trial aimed to evaluate the effects of wilting (wet vs wilted), particle size reduction (small vs large) and the addition of fibrolytic enzymes (alone vs combined with Lactobacillus plantarum) on the fermentation and ensiling losses of Tanzania grass (Panicum maximum, Jacq. cv. Tanzania). Forage was harvested and cut at 45-day vegetative re-growth period and stored in experimental plastic silos (50 L) during 136 days. During the storage period, the effluent flow was collected and measured at days 1 , 2, 7, 14, 21, 60, 90 and 136. Total silage losses were not affected by particle size reduction, even though the smallest particle size promoted better aerobic stability of the silage. The rate of silage DM recovery, effluent and gases losses were 72,5 e $23 \%$ for wet and 80,0 e $21 \%$ for wilted silages, respectively. The addition of fibrolytic enzymes exclusively or combined with Lactobacillus plantarum led to decreased concentrations of NDF, ADF, cellulose and hemicellulose mainly on wilted silages, however, no benefit was observed in the in vitro DM digestibility. Mean values for BOD $\left(11.289 \mathrm{mg} \mathrm{L}^{-1}\right)$, COD (36.279 $\left.\mathrm{mg} \mathrm{L}^{-1}\right)$, and the ratio COD/BOD (3.35) were observed on the effluent of wet silages, which increased the potential of environmental pollution with the longer silage storage period. 


\subsection{Introdução}

A utilização de produtos biotecnológicos incorporados nos alimentos de bovinos, como as enzimas fibrolíticas, vem sendo estudada por pesquisadores com o objetivo de proporcionar aumentos na eficiência de fermentação e utilização de forragens. As preparações enzimáticas são classificadas em função de sua especificidade e de seu modo de ação sobre o substrato. Os aditivos enzimáticos comerciais ou extratos fermentativos podem ser de origem bacteriana ou fúngica e apresentam um conjunto específico de atividade. Um extrato enzimático com atividade predominante de xilanase pode apresentar outras atividades enzimáticas, como de proteases, celulases, pectinases ou $\beta$-glucanases. As classes mais comuns de enzimas verificadas nesses produtos são as celulases e hemicelulases; amilases e pectinases também podem estar presentes. Por causa dessa grande diversidade entre os produtos enzimáticos, como a origem e o tipo, a sua eficiência, ou uso, varia substancialmente.

Em determinadas situações, a escassez de resultados positivos quanto à adição de enzimas em silagens pode ser atribuída ao substrato, ao método de aplicação das enzimas, ao tempo requerido para as enzimas atuarem sobre o material, ao conteúdo de matéria seca da forragem, ao $\mathrm{pH}$ ou à temperatura da digesta no trato do animal (Rode \& Beauchemin, 1999). Dentre estes fatores, a dose adequada de enzimas tem sido considerada crítica para obtenção de respostas positivas (Kung et al., 2000a; Treacher \& Hunt, 1996). O tipo de forragem, conforme Beauchemin et al. (1995), também influenciaria a aplicação da dose enzimática mais adequada para a obtenção de incremento de ganho de peso em bovinos. Mais especificamente, Marquardt et al. (1996) propuseram que o efeito das enzimas seria influenciado principalmente pelo tipo e pela concentração dos carboidratos ( $\beta$ - glucose e arabinoxilanas) presentes no alimento.

O teor de matéria seca da forragem merece destaque, por influenciar de forma significativa os resultados obtidos pela utilização das enzimas fibrolíticas. Segundo Muck \& Kung (1997), os aditivos enzimáticos contêm uma variedade de enzimas que hidrolisam a estrutura dos carboidratos da parede celular em açúcares, reduzindo o conteúdo da fibra, e, conseqüentemente, melhoram a digestão de forragens, 
principalmente daquelas em estágios avançados de desenvolvimento e, por isso, com maior conteúdo de matéria seca. Adicionalmente, os maiores efeitos da adição de enzimas foram verificados em fenos de alfafa (Medicago sativa L.) e Phleum pratense L., ou seja, em materiais com teores mais elevados de matéria seca, quando comparado às respostas obtidas em silagens. Feng et al. (1996), avaliando o efeito da adição de enzimas fibrolíticas (celulase e xilanase) em forragens com diferentes teores de umidade, obtiveram aumento na degradabilidade in situ da matéria seca e da fibra em detergente neutro quando as enzimas foram adicionadas na forragem com maior conteúdo de matéria seca.

O processamento mecânico da forragem pode alterar a fermentação da forragem, dependendo da extensão de danos no tecido vegetal. Assim, a redução do tamanho de partícula poderia ser favorável ao processo de fermentação, por facilitar a compactação da massa ensilada. De acordo com McDonald et al. (1991), o tamanho de partícula inferior a $20-30 \mathrm{~cm}$ pode favorecer a disponibilidade de carboidratos solúveis e, conseqüentemente, estimular o crescimento das baterias láticas. No entanto, existem controvérsias na literatura em relação à redução do tamanho de partícula da forragem, havendo efeitos positivos, relacionados ao grau de compactação observado em forragens com maior teor de matéria seca, e negativos, associados às perdas por efluente em forragens com menor teor de matéria seca (Loures, 2000; Nussio et al., 2002; Igarasi, 2002). Adicionalmente, as perdas por efluente representam perdas do valor nutricional e risco de poluição ambiental, que podem ser evitados utilizando forragens emurchecidas. Contudo, o efeito da aplicação de aditivos biológicos sobre a produção de efluente apresenta resultados contraditórios, podendo haver tanto redução quanto aumento da produção de efluente (Jones \& Jones, 1995; Jaster, 1995; Haigh, 1999).

Além de enzimas fibrolíticas na ensilagem, os inoculantes bacterianos são utilizados com fins de aumentar a população de bactérias desejáveis, estimular a fermentação lática e reduzir o $\mathrm{pH}$. Sua associação com enzimas fibrolíticas é recomendada por potencializar a fermentação das silagens, pois estas forneceriam o substrato para bactérias láticas. Castro (2002) verificou que, em silagens de capim Tifton 85 (Cynodon sp.) com 45\% de matéria seca, o uso de aditivos bacteriano-enzimáticos 
proporcionou a redução de $\mathrm{pH}$ e o incremento da estabilidade aeróbia da silagem. Nussio et al. (2002), em recente revisão, destacaram que os benefícios do uso de inoculantes bacteriano-enzimáticos, em silagens de capins tropicais, seriam o aumento da disponibilidade do carboidrato solúvel como substrato para bactérias láticas, reduzindo conseqüentemente o $\mathrm{pH}$, e o aumento da digestibilidade orgânica da forragem.

O objetivo deste experimento foi avaliar o efeito da adição de enzimas fibrolíticas - associadas ou não ao inoculante bacteriano, em silagem de capim Tanzânia (Panicum maximum, Jacq.) com diferentes tamanhos de partículas e teores de matéria seca - sobre a produção e composição de efluente.

\subsection{Material e Métodos}

\subsubsection{Local do experimento}

Este trabalho foi realizado no Departamento de Zootecnia da Escola Superior de Agricultura "Luiz de Queiroz" (ESALQ-USP). As análises bromatológicas foram conduzidas no Laboratório de Bromatologia, pertencente ao mesmo Departamento.

\subsubsection{Forragem, tratamentos e coleta de amostras}

A ensilagem do capim Tanzânia, com 45 dias de crescimento vegetativo, foi realizada nos dias 31 de janeiro, 1 e 4 de fevereiro de 2002. Os tratamentos impostos à forragem destinada à conservação foram constituídos pelos efeitos de: tamanho de partícula - maior e menor (de acordo com o distanciamento alcançado na regulagem da contrafaca); teor de matéria seca - emurchecida (com um período de secagem no campo de cinco horas) e contendo umidade original (ensilada imediatamente após o corte); e adição de enzimas fibrolíticas combinadas ou não ao inoculante bacteriano. Os tratamentos, com quatro repetições cada, são descritos a seguir: 
Tratamentos do capim Tanzânia sem emurchecimento:

- controle, sem aplicação de enzimas fibrolíticas:

$\mathrm{T}_{1}$ - forragem com partícula menor;

$\mathrm{T}_{2}$ - forragem com partícula maior.

- somente com aplicação de enzimas fibrolíticas:

$\mathrm{T}_{3}$ - forragem com partícula menor;

$\mathrm{T}_{4}$ - forragem com partícula maior.

- com aplicação de enzimas fibrolíticas mais inoculante bacteriano:

$\mathrm{T}_{5-}$ forragem com partícula menor;

$\mathrm{T}_{6}$ - forragem com partícula maior.

> Tratamentos do capim Tanzânia emurchecido:

- controle, sem aplicação de enzimas fibrolíticas:

$\mathrm{T}_{7}$ - forragem com partícula menor;

$\mathrm{T}_{8}$-ragem com partícula menor;

- somente com aplicação de enzimas fibrolíticas:

$\mathrm{T}_{9}$ - forragem com partícula menor;

$\mathrm{T}_{10}$ - forragem com partícula maior.

- com aplicação de enzimas fibrolíticas mais inoculante bacteriano:

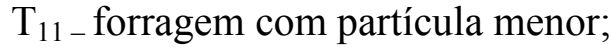

$\mathrm{T}_{12}$ - forragem com partícula maior.

O material ensilado foi acondicionado em 48 tambores, com volume de $50 \mathrm{~L}$ cada, dispostos em bancadas de madeira. Na porção superior, os tambores foram devidamente vedados com tampas de madeira e sacos plásticos; em sua parte inferior, havia mangueiras conectadas a garrafas de plástico, por onde era realizada a drenagem do efluente. Os silos experimentais, após sua pesagem, foram submetidos à determinada coluna de pressão, utilizando-se blocos de concretos, com o objetivo de simular a pressão existente em silos de maior escala.

Os cálculos para a determinação da carga de pressão a ser aplicada em cada silo 
foram efetuados da seguinte forma: considerando as dimensões dos tambores de $50 \mathrm{~L}$ (60 $\mathrm{cm}$ de altura, 34,5 cm de diâmetro, área de $0,094 \mathrm{~m}^{2}$ e volume de $0,056 \mathrm{~m}^{3}$ ) e o peso médio dos blocos de concreto $(9,75 \mathrm{~kg})$, fez-se o cálculo da pressão que deveria ser exercida sobre os silos experimentais. Para isso, foi utilizado como parâmetro um silo trincheira hipotético com base maior $(4,25 \mathrm{~m})$ e base menor $(3,25 \mathrm{~m}), 2 \mathrm{~m}$ de altura, com espessura de corte diário de $0,5 \mathrm{~m}$, gerando um volume de $3,75 \mathrm{~m}^{3}$. Assim, para tratamentos com silagem sem emurchecimento, foi considerada a densidade de $600 \mathrm{~kg}$ $\mathrm{m}^{-3}$ para obter a pressão desejada de $1.385 \mathrm{~kg} \mathrm{~m}^{-2}$. Multiplicando essa pressão pela área do tambor e descontando o peso da própria silagem, obteve-se o peso (96 kg) que deveria ser aplicado sobre os tambores. Portanto, para os tratamentos de silagens nãoemurchecidas foram necessários 10 blocos de concretos por silo. Ao longo dos dias de armazenamento, com a pesagem dos silos, o número de blocos foi sendo alterado conforme necessário, com o intuito de manter constante a pressão desejada.

O mesmo raciocínio foi realizado para os tratamentos de silagem emurchecida, porém a densidade estabelecida foi alterada para $400 \mathrm{~kg} \mathrm{~m}^{-3}$ e os valores de pressão, peso da coluna de concreto e número de blocos passaram para $923 \mathrm{~kg} \mathrm{~m}^{-2}, 64 \mathrm{~kg}$ e 7 blocos, respectivamente.

A quantidade necessária do aditivo enzimático foi misturada à forragem picada, utilizando-se um pulverizador com $500 \mathrm{~mL}$ de capacidade. Segundo a recomendação do fabricante Biotal Limited ${ }^{\circledR}$ (http://www.kfi4u.com/biotal_inoculants.htm), as aplicações realizadas durante o processo de ensilagem utilizaram $150 \mathrm{~g}$ da preparação enzimática, diluídos em $100 \mathrm{~L}$ de água; $2 \mathrm{~L}$ desta solução foram aplicados por tonelada de massa verde de capim picado, representando uma taxa de aplicação de $2 \mathrm{~mL} \mathrm{~kg}^{-1}$ da solução enzimática por quilo de forragem.

O inoculante bacteriano utilizado foi o ECOSIL ${ }^{\circledR}$ Silage Inoculant, da empresa ECOSYL Products Limited (http://www.ecosyl.com/us/usintro.htm), caracterizado por cepa de Lactobacillus plantarum, aplicado por aspersão, seguindo a recomendação técnica, com adição de 100 bilhões UFC viáveis por tonelada de massa verde de forragem.

Amostras compostas de forragem para cada tratamento foram coletadas à 
medida que se enchiam os silos experimentais. Após seu enchimento, cada silo, com a tara previamente identificada, foi pesado e vedado. Também foram tomadas as medidas volumétricas da forragem ensilada, para comparações posteriores.

O efluente foi coletado, sempre às 10 horas da manhã, no $1^{\circ}, 2^{\underline{0}}, 7^{\circ}, 14^{\underline{0}}, 21^{\underline{0}}$, $60^{\circ}, 90^{\circ}$ e $136^{\circ}$ dias, mensurado e armazenado em congelador $\left(-20^{\circ} \mathrm{C}\right)$ e geladeira $\left(-5^{\circ} \mathrm{C}\right)$ para análises futuras; juntamente com a coleta do efluente, foi feita a pesagem dos silos. O volume do efluente foi mensurado a cada 12 horas na primeira semana, 24 horas até o $30^{\circ}$ dia, 48 horas até o $60^{\circ}$ dia e 72 horas até a abertura dos silos.

Após os 136 dias de armazenamento, foram realizadas as amostragens das silagens para posteriores análises bromatológicas e registradas as medidas volumétricas da massa ensilada dentro do silo. A perda de matéria seca na forma de gases foi calculada pela diferença entre o peso bruto inicial e final dos silos.

\subsubsection{Parâmetros físicos}

Com vistas ao cálculo de algumas variáveis físicas relacionadas à silagem de capim Tanzânia, foram utilizadas fórmulas descritas na literatura, que permitiram inferir a acomodação da massa ensilada. As Equações 1 e 2, que descrevem a alteração volumétrica e compressibilidade, foram propostas por O'Donnell et al. (1997a). A Equação 3, sobre porosidade, foi uma adaptação da equação proposta por O'Donnell et al. (1997b), e a Equação 4, sobre permeabilidade, foi utilizada conforme Williams et al. (1997).

$$
\text { Alteração volumétrica }=\ln \frac{(\text { Volume inicial })}{(\text { Volume final })}
$$

$$
\text { Compressibilidade }=\underline{\text { Alteração volumétrica }}
$$

Pressão $(\mathrm{Pa})$ 
Porosidade $=1-($ Densidade inicial $X \%$ MS inicial $) \times 100$

(Densidade final $X \% \mathrm{MS}$ final)

Equação (3)

Permeabilidade $=673-0,614 \times \%$ MS $-0,616 \times$ densidade da massa verde

Equação (4)

\subsubsection{Estabilidade aeróbia}

A avaliação da estabilidade aeróbia das silagens foi realizada, após a abertura dos silos, através da manutenção de uma alíquota de silagem não-compactada em baldes sem tampas, em duas repetições por tratamento, dispostos numa sala em temperatura ambiente.

Um termômetro foi posicionado no centro geométrico, no interior da massa de silagem, em cada balde. Para a medida da temperatura ambiente, um termômetro de bulbo de mercúrio foi inserido dentro de uma caixa de isopor contendo água, com a finalidade de evitar maiores variações da temperatura do ar. Duas vezes ao dia, os baldes foram pesados, sendo as medidas de temperatura registradas em cada balde e no ambiente, durante 10 dias após a abertura dos silos. Ao término dos 10 dias, foi realizada a amostragem do material, para avaliação da percentagem de perdas de MS. A avaliação da estabilidade seguiu a metodologia descrita por O’Kiely et al. (2002).

\subsubsection{Determinação das perdas de MS por gases e efluente e de sua taxa de recuperação}

As perdas de MS por gases foram calculadas conforme a Equação 5, e as perdas de MS por efluente foram determinadas pela diferença entre a taxa de recuperação da MS e o valor calculado para perdas por gases. A Equação 6 representa o cálculo para a determinação da taxa de recuperação da matéria seca. 


$$
G=\frac{(M F \times M S F)-(M S \times M S S+P E F)}{(M F \times M S F)} \times 100
$$

em que:

$\mathrm{G}=$ perdas por gases $(\% \mathrm{MS})$;

$\mathrm{MF} \quad=$ massa de forragem $(\mathrm{kg})$;

$\mathrm{MSF}=$ percentagem de MS da forragem (\%);

MS = massa da silagem $(\mathrm{kg})$;

MSS = percentagem de MS da silagem (\%); e

$\mathrm{PEF} \quad=$ peso do efluente $(\mathrm{kg} \mathrm{MS})$.

$$
\mathrm{RMS}=\frac{(\mathrm{MS} \times \mathrm{MSS})}{(\mathrm{MF} \times \mathrm{MSF})} \times 100
$$

Equação (6)

em que:

RMS = taxa de recuperação de matéria seca (\%);

MS = massa da silagem $(\mathrm{kg})$;

MSS = percentagem de MS da silagem (\%);

$\mathrm{MF} \quad=$ massa de forragem $(\mathrm{kg})$; e

MSF = percentagem de MS da forragem (\%).

\subsubsection{Análises laboratoriais}

As amostras do material ensilado e das silagens armazenadas foram descongeladas, secas em estufa de circulação forçada a $60^{\circ} \mathrm{C}$ por 72 horas, moídas em tamanhos de partícula de $1 \mathrm{~mm}$ e, posteriormente, submetidas às seguintes análises: FDN e FDA, segundo Van Soest et al. (1991), MS (Silva, 1990) e matéria mineral (MM) (AOAC, 1990). A determinação do $\mathrm{N}$ foi obtida através da combustão da amostra, segundo o método de Dumas, utilizando-se um auto-analisador de nitrogênio, da marca 
LECO, modelo FP-528 (Wiles et al., 1998). As frações FDN e FDA foram determinadas utilizando-se o equipamento "Fiber Analyser Ankon 2000". A lignina foi determinada através do método LDA (lignina em detergente ácido), pelo uso de solução de ácido sulfúrico a 72\%, após a determinação de FDA, utilizando-se o equipamento "Daisy Incubator Ankon". Empregando-se este mesmo equipamento, foi determinada a digestibilidade in vitro da matéria seca (DIVMS), conforme Holden (1999). A fração hemicelulose foi obtida pela diferença da FDN e FDA, e a celulose, pela diferença da FDA e lignina.

Para as análises de carboidratos solúveis e nitrogênio amoniacal, foram preparados extratos aquosos da silagem, conforme Kung Junior et al. (1984), e armazenados em freezer. Posteriormente, para carboidratos solúveis, foi utilizada a metodologia proposta por Dubois et al. (1956) e, para nitrogênio amoniacal, seguiu-se o método colorimétrico descrito por Okuda et al. (1965), adaptado para uso em placas de microtúbulo com mensuração em Colorímetro - Elisa Reader (absorbância de 550 nanômetros).

A avaliação da estratificação de partículas das silagens foi feita segundo adaptação da metodologia das peneiras seqüenciais do "Penn State Particle Size Separator", proposta por Lammers et al. (1996), definindo a percentagem de material de diâmetro superior a $38 \mathrm{~mm}$ (peneira 1), intermediários de 38 a $19 \mathrm{~mm}$ (peneira 2) e 19 a $7,9 \mathrm{~mm}$ (peneira 3) e inferior a 7,9 $\mathrm{mm}$.

O efluente foi analisado, para verificação da demanda bioquímica de oxigênio (DBO) e demanda química de oxigênio (DQO), pelo laboratório Bioagri Ambiental Ltda (http://www.bioagri.com.br/homebioagri.htm), segundo o protocolo da APHA (1995); as demais análises - $\mathrm{pH}$, sólidos totais e sólidos totais fixos - foram realizadas segundo Silva (1977).

A determinação da condutividade elétrica da silagem (CE) foi realizada conforme metodologia proposta por Kraus et al. (1997), com a utilização do condutivímetro CD-20 Digimed ${ }^{\circledR}$. 


\subsubsection{Delineamento experimental e análises estatísticas}

As variáveis da silagem (MS, PB, CHOs, MM, FDN, FDA, lignina e DIVMS) foram estudadas para cada tamanho de partícula, teor de MS e tipo de tratamento enzimático, com ou sem inoculante bacteriano, adotando-se o delineamento inteiramente casualizado em arranjo fatorial $2 \times 2 \times 3$, empregando o procedimento GLM, com suas médias testadas usando a opção PDIFF do SAS (2002). Adotou-se como co-variável o valor das análises bromatológicas da forragem de algumas variáveis da silagem.

As variáveis de $\mathrm{DBO}, \mathrm{DQO}, \mathrm{DQO} / \mathrm{DBO}, \mathrm{pH}$, sólidos totais, sólidos totais fixos foram analisadas como parcelas subdivididas repetidas no tempo, utilizando $\mathrm{o}$ procedimento MIXED. Contudo, em função dos dados obtidos, na análise estatística, foram considerados apenas os dados dos 60, 90 e 136 dias de armazenamento.

Os dados foram interpretados estatisticamente por meio de análise de variância, e os modelos escolhidos foram baseados no coeficiente de determinação e na significância, adotando-se os níveis de 1, 5 e 10\% de probabilidade, utilizando-se o teste F.

\subsection{Resultados e Discussão}

\subsubsection{Características do capim Tanzânia utilizado na ensilagem}

Observaram-se teores médios de matéria seca para o capim não-emurchecido e emurchecido de 16,74 e 25,71\%, respectivamente (Tabela 1). Apesar de as condições para realizar o emurchecimento da forragem terem sido limitadas em função da incidência de chuvas na época da realização do experimento de campo, o resultado de $25,71 \%$ pode ser considerado satisfatório na comparação entre as silagens. A elevação de nove unidades percentuais no teor de matéria seca da forragem durante o período de cinco horas de exposição à desidratação resultou no incremento médio de 1,8 unidade 
Tabela 1. Composição química e pH do capim Tanzânia utilizado na ensilagem

\begin{tabular}{|c|c|c|c|c|c|c|c|c|c|c|c|c|}
\hline \multirow{3}{*}{ Variáveis } & \multicolumn{6}{|c|}{ Sem emurchecimento } & \multicolumn{6}{|c|}{ Com emurchecimento } \\
\hline & \multicolumn{2}{|c|}{ ENZ (-) } & \multicolumn{2}{|c|}{ ENZ $(+)$} & \multicolumn{2}{|c|}{$\mathrm{ENZ}+\mathrm{B}$} & \multicolumn{2}{|c|}{ ENZ (-) } & \multicolumn{2}{|c|}{ ENZ (+) } & \multicolumn{2}{|c|}{$\mathrm{ENZ}+\mathrm{B}$} \\
\hline & $\mathrm{TP}<$ & $\mathrm{TP}>$ & $\mathrm{TP}<$ & $\mathrm{TP}>$ & $\mathrm{TP}<$ & $\mathrm{TP}>$ & $\mathrm{TP}<$ & $\mathrm{TP}>$ & $\mathrm{TP}<$ & $\mathrm{TP}>$ & $\mathrm{TP}<$ & $\mathrm{TP}>$ \\
\hline MS, \% & 15,2 & 16,1 & 16,1 & 16,9 & 19,3 & 16,9 & 23,4 & 29,3 & 25,2 & 26,7 & 23,8 & 26,0 \\
\hline $\mathrm{pH}$ & 5,97 & 6,16 & 6,09 & 6,12 & 6,12 & 6,08 & 6,36 & 6,31 & 6,24 & 6,28 & 6,31 & 6,31 \\
\hline & \multicolumn{12}{|c|}{$\% \mathrm{MS}$} \\
\hline PB & 6,70 & 5,29 & 5,99 & 5,37 & 5,26 & 6,72 & 9,32 & 4,38 & 7,12 & 5,78 & 8,54 & 5,22 \\
\hline FDN & 69,7 & 71,0 & 71,8 & 72,3 & 73,1 & 72,4 & 70,2 & 73,7 & 71,4 & 72,7 & 70,8 & 72,1 \\
\hline FDA & 42,3 & 37,4 & 42,1 & 38,4 & 41,3 & 40,0 & 39,4 & 41,8 & 40,9 & 41,7 & 41,7 & 42,7 \\
\hline CEL & 36,0 & 32,0 & 36,8 & 33,1 & 36,4 & 33,9 & 34,8 & 36,5 & 34,8 & 37,3 & 34,6 & 37,1 \\
\hline HEMI & 27,4 & 32,6 & 29,7 & 33,9 & 31,8 & 32,4 & 30,9 & 32,1 & 30,5 & 31,0 & 29,2 & 27,4 \\
\hline Lignina & 4,15 & 2,87 & 3,80 & 3,59 & 3,53 & 4,70 & 3,84 & 3,70 & 4,24 & 3,78 & 5,20 & 3,61 \\
\hline CHOs & 5,74 & 6,78 & 5,91 & 6,51 & 4,86 & 6,20 & 3,99 & 3,85 & 4,11 & 5,33 & 4,73 & 4,56 \\
\hline DIVMS & 67,8 & 71,5 & 69,3 & 71,1 & 70,3 & 70,9 & 69,4 & 63,9 & 69,3 & 68,0 & 69,0 & 67,8 \\
\hline Cinza & 12,5 & 9,9 & 10,6 & 10,1 & 10,2 & 10,6 & 11,1 & 10,3 & 11,2 & 11,1 & 11,7 & 11,7 \\
\hline
\end{tabular}

ENZ (-) = sem enzimas fibrolíticas, ENZ $(+)=$ com enzimas fibrolíticas e ENZ+B = com enzimas fibrolíticas mais inoculante bacteriano.

$\mathrm{TP}<=$ tamanho de partícula menor e TP $>$ = tamanho de partícula maior.

percentual por hora. Essa taxa de desidratação é maior que aquela observada por Igarasi (2002) estudando o emurchecimento, com período de seis horas, do capim Tanzânia para a produção de silagem no verão. Embora não se tenha atingido o teor de matéria seca suficiente para eliminar a ocorrência de efluente, nas silagens emurchecidas, a geração de efluente foi esporádica. Apesar de Mülbach (1998) ter ressaltado que a desidratação parcial da forragem verde em teores acima de 25\% é capaz de suprimir a produção de efluente e Loures (2000) não ter verificado produção de efluente em silagens de capimelefante com $25 \%$ de matéria seca, muitos pesquisadores consideram que os valores mínimos de matéria seca para inibir a produção de efluente estariam na faixa de 29 a 30\% (Bastiman, 1976; Zimmer, 1967, citado por Woolford,1984).

A composição bromatológica média da forragem de capim Tanzânia, para as variáveis analisadas, apresentou resultados semelhantes aos encontrados na literatura (Igarasi, 2002; Brâncio et al., 2002), e serão discutidas posteriormente como covariáveis das silagens obtidas no presente experimento. 


\subsubsection{Avaliação das silagens experimentais}

\subsubsection{Granulometria e parâmetros físicos}

As silagens foram avaliadas quanto ao tamanho de partícula, através de uma adaptação da metodologia proposta por Lammers et al. (1996), com acréscimo de uma peneira com orifícios de $38 \mathrm{~mm}$. A avaliação dos dados pelo teste $\mathrm{F}$ do percentual de material retido nas peneiras revelou diferença significativa $(\mathrm{P}<0,05)$ para teor de $\mathrm{MS}$, tamanho de partícula, enzimas e tratamento aplicado.

A metodologia proposta por Lammers et al. (1996) apresenta algumas limitações quanto à separação das partículas com maior teor de umidade, devido à sobreposição e ao agrupamento das partículas de silagem, que impossibilitam a estratificação do material pelos orifícios da peneira. Talvez isso explique o fato de as silagens não-emurchecidas apresentarem tamanhos de partículas maiores do que as silagens emurchecidas (59 vs. 57\% na peneira 1; 22 vs. 19\% na peneira 2), conforme pode ser verificado na Tabela 2. Igarasi (2002) também relatou a dificuldade na estratificação das partículas de forragens utilizando apenas duas peneiras para evidenciar as diferenças entre tamanhos de partículas. Isso acentua ainda mais a importância do acréscimo de outra peneira na metodologia original.

Na avaliação entre os tamanhos de partículas, verificou-se que, para os tamanhos de partículas menores, 56\% da amostra de forragem ficou retida na peneira 1; 24\%, na peneira 2; 15\%, na peneira 3; e apenas 5\% apresentaram tamanho inferior a 7,9mm. Nas silagens com maior tamanho de partícula: 60\% ficaram retidos na peneira 1; 17\%, na peneira 2; 16\%, na peneira 3; e 7\% apresentavam tamanho inferior a 7,9 mm. Por meio desse resultado, pode-se inferir que a regulagem do equipamento para reduzir o tamanho da partícula da forragem foi eficaz na obtenção de diferentes tamanhos de partículas (maior e menor).

Em relação ao efeito das enzimas fibrolíticas, é importante destacar que os tratamentos com aplicação de enzimas fibrolíticas mais inoculante bacteriano 
Tabela 2. Retenção percentual de partículas de capim Tanzânia, utilizando-se método “Penn State Particle Size Separator” adaptado

\begin{tabular}{lcccc}
\hline \multirow{2}{*}{ Variáveis } & \multicolumn{4}{c}{ \% Material retido } \\
& P1 & P2 & P3 & $<7,9 \mathrm{~mm}$ \\
\hline $\mathrm{TP}<$ & $55,8^{\mathrm{b}}$ & $24,0^{\mathrm{a}}$ & $15,1^{\mathrm{b}}$ & $4,6^{\mathrm{b}}$ \\
$\mathrm{TP}>$ & $59,8^{\mathrm{a}}$ & $16,5^{\mathrm{b}}$ & $16,3^{\mathrm{a}}$ & $6,5^{\mathrm{a}}$ \\
& & & & \\
$\mathrm{SE}$ & $58,8^{\mathrm{a}}$ & $21,5^{\mathrm{a}}$ & $14,6^{\mathrm{b}}$ & $4,7^{\mathrm{b}}$ \\
EM & $56,8^{\mathrm{b}}$ & $18,9^{\mathrm{b}}$ & $16,8^{\mathrm{a}}$ & $6,4^{\mathrm{a}}$ \\
& & & & \\
ENZ (-) & $56,8^{\mathrm{b}}$ & $21,4^{\mathrm{a}}$ & $15,5^{\mathrm{b}}$ & $5,8^{\mathrm{a}}$ \\
ENZ (+) & $56,8^{\mathrm{b}}$ & $20,0^{\mathrm{a}}$ & $16,5^{\mathrm{b}}$ & $5,5^{\mathrm{b}}$ \\
ENZ + B & $59,8^{\mathrm{a}}$ & $19,1^{\mathrm{a}}$ & $15,1^{\mathrm{a}}$ & $5,4^{\mathrm{b}}$ \\
\hline P1, P2, P3 & & & &
\end{tabular}

P1, P2, P3 - são as peneiras.

ENZ $(-)=$ sem enzimas fibrolíticas, ENZ $(+)=$ com enzimas fibrolíticas e ENZ+B = com enzimas fibrolíticas mais inoculante bacteriano.

$\mathrm{TP}<=$ tamanho de partícula menor e TP $>=$ tamanho de partícula maior.

$\mathrm{SE}=$ sem emurchecimento e EM = emurchecida.

Médias na coluna seguidas de mesmas letras minúsculas não diferem entre si ( $\mathrm{P}>0,05)$.

apresentaram os maiores tamanhos de partícula em comparação com aqueles sem enzimas ou com enzimas aplicadas isoladamente (60 vs. 57\% da forragem ficou retida na peneira 1). Portanto, sob tais circunstâncias, esse resultado deve ser considerado posteriormente na análise da quantidade de efluente produzida em determinados tratamentos.

Na avaliação dos parâmetros físicos da forragem (Tabela 3), verificou-se que somente para o teor de matéria seca houve efeito significativo da densidade $(\mathrm{P}<0,10)$, da compressibilidade $(\mathrm{P}<0,01)$ e da porosidade $(\mathrm{P}<0,01)$. Segundo Muck \& Holmes $(2000)$, a redução do tamanho de partícula poderia garantir melhor eficiência de fermentação da silagem, devido à maior acomodação da massa ensilada, que, conseqüentemente, promoveria maior compactação e densidade. 
Tabela 3. Parâmetros físicos da silagem de capim Tanzânia com diferentes teores de MS, tamanho de partícula e aplicações enzimáticas

\begin{tabular}{|c|c|c|c|c|c|c|c|c|c|}
\hline \multirow{2}{*}{$\begin{array}{l}\text { Parâmetros } \\
\text { Físicos }\end{array}$} & \multicolumn{2}{|c|}{$\begin{array}{l}\text { Conteúdo de } \\
\text { matéria seca }\end{array}$} & \multicolumn{7}{|c|}{ Efeitos e Interações (P>F) } \\
\hline & $\mathrm{SE}$ & EM & MS & $\mathrm{TP}$ & MS*TP & $\mathrm{E}$ & MS*E & $\mathrm{TP} * \mathrm{E}$ & $\mathrm{MS} * \mathrm{TP} * \mathrm{E}$ \\
\hline Densidade, $\mathrm{kg} \mathrm{m}^{-3}$ & 795 & 773 & $\dagger$ & ns & ns & ns & ns & ns & ns \\
\hline Porosidade, \% & 28 & 14 & $* *$ & ns & ns & ns & ns & ns & ns \\
\hline Permeabilidade & 183 & 172 & ns & ns & ns & ns & ns & ns & ns \\
\hline Compressibilidade & 65 & 33 & $* *$ & ns & ns & ns & ns & ns & ns \\
\hline
\end{tabular}

As silagens não-emurchecidas apresentaram maior densidade que as emurchecidas, porém o tamanho de partícula não influenciou os parâmetros físicos da forragem. Adicionalmente, também não houve redução da porosidade, o que talvez esteja relacionado à menor amplitude de variação no tamanho de partícula e respectivas densidades entre as silagens emurchecidas e contendo umidade original. O benefício em reduzir a porosidade da massa ensilada afeta diretamente a taxa na qual o oxigênio permeia a massa ensilada, controlando, assim, as taxas de respiração da forragem e de microrganismos.

Muck \& Holmes (2001) observaram maior porosidade em silagens com menor tamanho de partícula. De acordo com Paziani \& Nussio (2002), o maior volume de poros em silagens de menor tamanho de partículas seria composto por aqueles de menor tamanho, o que deveria tornar menos efetiva a permeação de oxigênio na massa, garantindo uma compactação mais eficaz; por isso, a permeabilidade seria um parâmetro mais interessante para mensurar a qualidade de compactação que a porosidade propriamente dita. Contudo, nesse experimento, não foram detectados efeitos da permeabilidade e de tamanho de partícula sobre a porosidade nas silagens avaliadas.

O’Donnell et al. (1997a) destacam a compressibilidade como fator importante na avaliação da produção de efluente. Segundo os autores citados, a compressibilidade aumenta com os dias de armazenamento da silagem. Nesse caso, a constatação de maior 
compressibilidade das silagens não-emurchecidas poderia estar relacionada à presença de umidade auxiliando na acomodação da massa. Por outro lado, as silagens emurchecidas, como esperado, mostraram-se mais resistentes à compressão.

\subsubsection{Estabilidade aeróbia}

A estabilidade aeróbia da silagem está associada à redução do desenvolvimento de bactérias, fungos e leveduras, responsáveis por alterações microbiológicas após a abertura do silo. A pós-fermentação será mais intensa quanto melhor for a qualidade da silagem, em razão dos maiores teores de carboidratos solúveis e de ácido lático residuais (Pereira \& Reis, 2002).

No presente trabalho, a estabilidade aeróbia foi avaliada como sendo o tempo observado para que a massa de silagem, depois de retirada do silo, apresentasse elevação de temperatura de $2^{\circ} \mathrm{C}$ em relação à temperatura de referência (ambiente). Adicionalmente, como outra forma de avaliação, a estabilidade aeróbia também foi caracterizada pela temperatura acumulada durante cinco e dez dias após a abertura dos silos experimentais, conforme O’Kiely et al. (1999), com modificações propostas por O’Kiely et al. (2002). Os maiores acúmulos de temperatura significam maior aquecimento da massa ensilada após a abertura, decorrente da maior intensidade de reações promovidas pelos microrganismos ao ambiente aeróbio, os quais se utilizam dos nutrientes disponíveis na silagem, provocando perdas no valor nutritivo (McDonald et al., 1991; Balsalobre et al., 2001).

Os resultados dos tratamentos e dos respectivos acúmulos de temperatura, nos cinco e dez primeiros dias após abertura dos silos experimentais, estão apresentados na Tabela 4. Verificou-se que houve efeito de teor de MS $(\mathrm{P}<0,01)$ nas médias das temperaturas acumuladas na silagem nos primeiros cinco dias, $12{ }^{\circ} \mathrm{C} \mathrm{e}-5{ }^{\circ} \mathrm{C}$, e nos dez dias, $17^{\circ} \mathrm{C}$ e $-7^{\circ} \mathrm{C}$, para os tratamentos contendo umidade original e emurchecidos, 
Tabela 4. Variáveis consideradas na avaliação da estabilidade aeróbia em silagens de capim Tanzânia com e sem adição de enzimas fibrolíticas

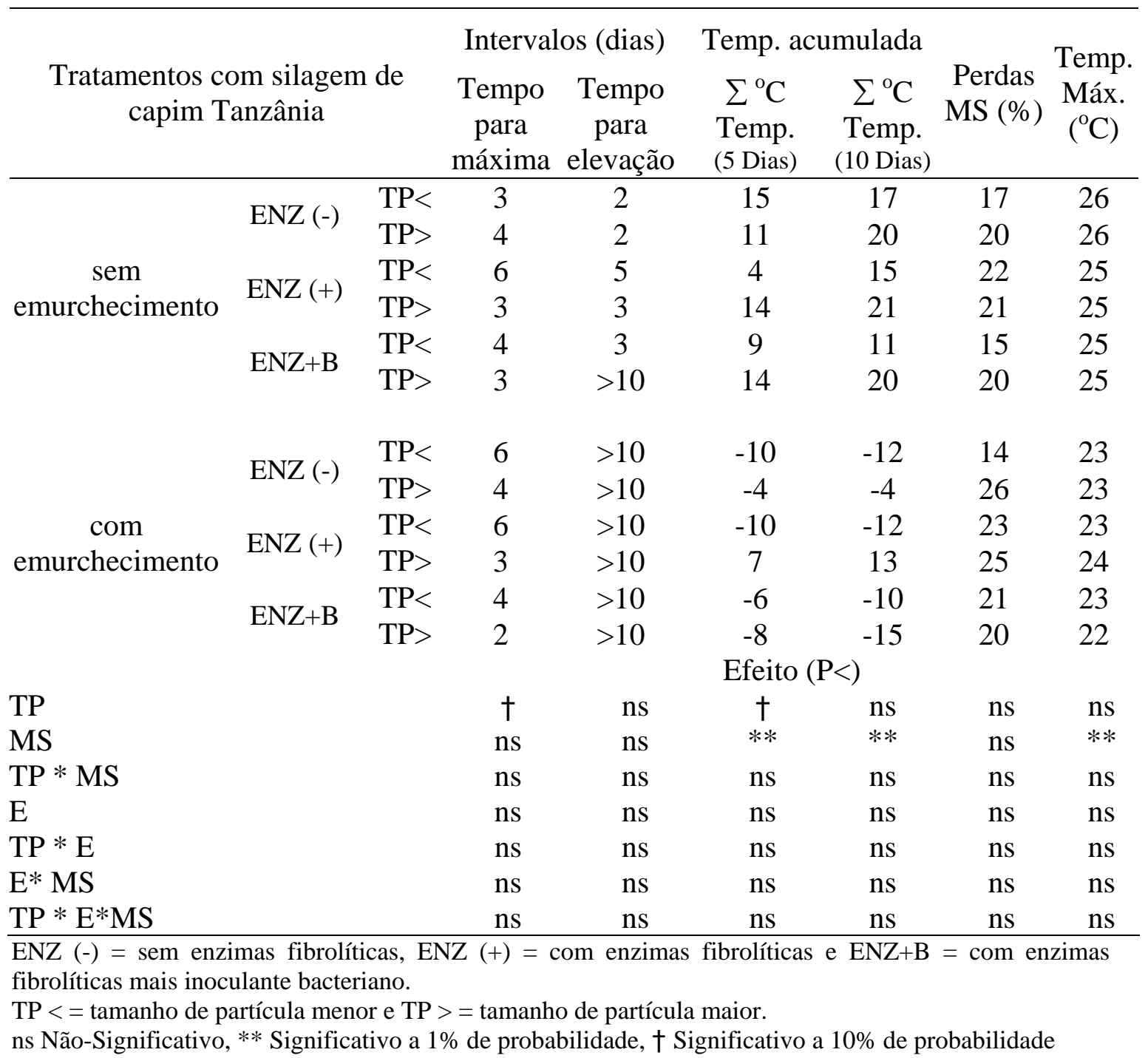

respectivamente. Pôde-se observar que, em termos de acúmulos de temperatura, as silagens emurchecidas apresentaram menor aquecimento quando comparadas às nãoemurchecidas, indicando possivelmente que o perfil pós-fermentativo das silagens com emurchecimento proporcionou redução do crescimento de bactérias indesejáveis, fungos e leveduras com maior eficácia do que as silagens mais úmidas. Esses dados estão de acordo com Castro (2002), que observou, em silagens de capim Tifton 85 emurchecidas, 
restrição no crescimento de microrganismos e, conseqüentemente, redução na fermentação, resultando em maior estabilidade aeróbia das silagens produzidas.

Essa redução do número de leveduras muitas vezes pode estar relacionada com a quantidade de ácidos graxos voláteis presentes na silagem, principalmente de ácidos propiônico e acético, que são reconhecidos inibidores do crescimento de leveduras (Stefanie et al., 2000). Quando a silagem é exposta ao ar, a levedura metaboliza o ácido lático, gerando $\mathrm{CO}_{2}$, etanol e ácido acético, aumentando o $\mathrm{pH}$ e permitindo o crescimento de microrganismos que promovem a deterioração da silagem (Kung Junior, 2001). Berto \& Muhlback (1997) observaram que o processo de emurchecimento determinou menor produção de ácidos totais, com maior relação ácido lático/acético, reduziu a produção de amônia, restringiu a produção de ácido butírico na silagem e economizou glicídios solúveis, além de diminuir a solubilização do nitrogênio protéico e evitar produção de efluente.

Em comparação com o presente experimento, Igarasi (2002) observou maiores acúmulos de temperatura. Essas diferenças poderiam ser, ao menos parcialmente, justificadas pela alteração metodológica empregada na avaliação da temperatura referência do experimento em questão. No trabalho de Igarasi (2002), a temperatura referência foi obtida por acompanhamento de um termômetro posicionado no local onde foram dispostos os silos experimentais.

Em decorrência da grande variação encontrada no ambiente, decidiu-se pela tomada da temperatura referência proposta por O’Kiely et al. (1999), com a imersão do termômetro em caixa de isopor contendo uma lâmina de água de aproximadamente 20 cm. Apesar dessas diferenças, é provável que outros fatores tenham ocasionado elevações das temperaturas acumuladas nas silagens avaliadas por Igarasi (2002), como, por exemplo, a época do ano (inverno e verão).

Um aspecto importante que poderia contestar os efeitos positivos do processo de emurchecimento sobre a estabilidade aeróbia seria o fato de que as perdas de nutrientes solúveis devido ao processo de respiração de carboidratos pela planta, durante o emurchecimento no campo, seriam capazes de provocar redução da quantidade de 
carboidratos residuais. Contudo, no presente experimento, essas perdas foram reduzidas, provavelmente em decorrência do curto período de exposição ao emurchecimento.

Foi verificado efeito significativo $(\mathrm{P}<0,01)$ do conteúdo de MS para a máxima temperatura da silagem; as silagens emurchecidas apresentaram menor temperatura $\left(23^{\circ} \mathrm{C}\right)$ que as não-emurchecidas $\left(25^{\circ} \mathrm{C}\right)$. Esse fato reforça a hipótese de que as silagens emurchecidas foram mais estáveis.

Portanto, a partir dos resultados obtidos, pode-se concluir que a silagens emurchecidas apresentaram maior estabilidade aeróbia que as não-emurchecidas, entretanto não houve diferença na avaliação de perdas por MS no período de 10 dias. Isso se deve, provavelmente, às condições climáticas no momento da abertura do silo, uma vez que a silagem produzida no verão foi aberta no final do mês junho, período em que a temperatura média do ambiente foi de $21,8^{\circ} \mathrm{C}$. Assim, a baixa temperatura do ambiente poderia ter contribuído para a redução do processo de deterioração e perdas pós-abertura dos silos experimentais. Indica também que possivelmente existem perdas de MS não necessariamente traduzidas por elevação de temperatura, confirmando observações prévias de Bernardes (2003).

Houve efeito significativo de tamanho de partícula $(\mathrm{P}<0,10)$ nos tratamentos estudados. Esse fato mostra que a redução do tamanho de partícula foi responsável por alterações na estabilidade aeróbia da silagem, conforme havia sido reportado por Igarasi (2002), sugerindo que, após a abertura, as partículas menores poderiam evitar a plena aeração devido a uma maior acomodação.

Guim et al. (2002), avaliando a estabilidade aeróbia em silagens de capimelefante emurchecido e tratado com inoculante microbiano, constataram que o uso de inoculante não exerceu influência sobre o desenvolvimento de leveduras; contudo, a partir de seis dias de exposição ao ar, as silagens inoculadas passaram a apresentar menor velocidade de deterioração.

A adição de enzimas fibrolíticas e inoculante bacteriano e suas respectivas interações com a MS e o tamanho de partícula não promoveram alterações significativas sobre os parâmetros avaliados de estabilidade aeróbia. A provável explicação para os resultados obtidos seria que a estabilidade das silagens, com enzimas ou associadas a 
inoculantes bacterianos, não acarretou maior teor de ácido lático em função do tratamento aplicado. Segundo Muck \& Kung Junior (1997), as enzimas fibrolíticas podem reduzir as perdas por deterioração aeróbia, compensando as maiores perdas por efluente, porém a estabilidade aeróbia, geralmente, apresenta resultados variáveis e inconsistentes em boa parte dos estudos.

Uma das dificuldades observadas na comparação dos resultados em relação à estabilidade aeróbia de silagens talvez esteja na falta de padronização de sua determinação. Observa-se, nos trabalhos mais recentes, que a temperatura estipulada de elevação em relação à temperatura ambiente varia de 1 a $3^{\circ} \mathrm{C}$, conforme as condições experimentais (Uriarte-Archundia et al., 2002a, 2002b; Wyss, 2002; Pflaum et al., 2002; Zastawny et al., 2002; O’Kiely et al., 2001; Taylor et al., 2002). Por isso, outros fatores devem ser considerados conjuntamente na avaliação da estabilidade de uma silagem, como contagem de bactérias e leveduras, avaliação do $\mathrm{pH}$, umidade relativa do ar e temperatura de acúmulo.

Além disso, convencionou-se avaliar as possíveis perdas de MS após a abertura do silo através da elevação da temperatura da massa, em decorrência da provável correspondência entre temperatura e perdas. No entanto, as avaliações de silagens de forragens tropicais vêm freqüentemente encontrando dificuldades em confirmar essa correlação, inclusive no presente trabalho. Isso sugere a busca por alternativas de mensuração para avaliar a estabilidade aeróbia dessas silagens.

\subsubsection{Condutividade elétrica}

Os resultados obtidos sobre a condutividade elétrica, como também sobre outras variáveis da composição química das silagens, podem ser verificados na Tabela 5. A mensuração da condutividade elétrica do material em análise é expressa em $\mu \mathrm{cm}^{-1}$, a qual fornece a intensidade da ruptura celular pelo corte da forragem. Segundo Kraus et al. (1997), o efeito do processamento físico resultante do corte da forragem reflete a drenagem do conteúdo celular devido à ruptura da parede celular da planta e pode ser quantificado por meio da determinação da condutividade. No presente estudo, não foi 
Tabela 5. Composição química das silagens de capim Tanzânia com diferentes teores de MS, tamanho de partícula e aplicações enzimáticas

\begin{tabular}{|c|c|c|c|c|c|c|c|c|c|c|c|c|c|c|c|c|}
\hline \multirow[t]{2}{*}{ Variáveis } & \multicolumn{3}{|c|}{ Enzimas fibrolíticas } & \multicolumn{2}{|c|}{$\begin{array}{l}\text { Tamanho } \\
\text { de } \\
\text { partícula }\end{array}$} & \multicolumn{2}{|c|}{$\begin{array}{c}\text { Conteúdo de } \\
\text { MS }\end{array}$} & \multirow[t]{2}{*}{$\begin{array}{l}\text { CV } \\
(\%)\end{array}$} & \multicolumn{7}{|c|}{ Efeitos e Interações $(\mathrm{P}>\mathrm{F})$} & \multirow[t]{2}{*}{$\begin{array}{c}\text { Co- } \\
\text { variável }^{1}\end{array}$} \\
\hline & ENZ (-) & $\operatorname{ENZ}(+)$ & $\mathrm{ENZ}+\mathrm{B}$ & $3<$ & $>$ & SE & EM & & MS & $\mathrm{TP}$ & MS*TP & $\mathrm{E}$ & MS*E & $\mathrm{TP} * \mathrm{E}$ & MS*TP*E & \\
\hline$\overline{M S, \%}{ }^{2}$ & 19,1 & 20,9 & 20,0 & 20,2 & 19,8 & 18,0 & 22,0 & 29 & $* *$ & ns & ns & $\dagger$ & ns & ns & ns & - \\
\hline PB, \%MS & 5,04 & 4,44 & 4,81 & 4,77 & 4,76 & 3,91 & 5,61 & 21 & $* *$ & ns & ns & ns & ns & ns & ns & $* *$ \\
\hline FDN, \%MS & 70,7 & 70,1 & 69,63 & 70,1 & 70,2 & 72,4 & 67,9 & 2 & $* *$ & ns & ns & ns & $*$ & ns & ns & $* *$ \\
\hline FDA, \%MS & 44,4 & 43,6 & 41,7 & 43,3 & 43,3 & 44,4 & 42,1 & 2 & $* *$ & ns & ns & $* *$ & ns & ns & ns & $* *$ \\
\hline CEL, \%MS & 38,2 & 37,6 & 36,3 & 37,3 & 37,4 & 38,7 & 35,9 & 3 & $* *$ & ns & ns & $* *$ & ns & ns & ns & $* *$ \\
\hline HEMI, \%MS & 26,0 & 26,7 & 27,9 & 26,8 & 27,0 & 28,1 & 25,7 & 5 & $* *$ & ns & ns & $* *$ & ns & ns & ns & $*$ \\
\hline Lignina, \%MS & 4,57 & 4,17 & 4,06 & 4,31 & 4,23 & 4,17 & 4,37 & 14 & ns & ns & ns & $\dagger$ & $*$ & ns & $*$ & ns \\
\hline CHOS, \%MS & 0,91 & 1,11 & 0,99 & 1,01 & 0,99 & 0,88 & 1,12 & 19 & $*$ & ns & ns & $*$ & ns & ns & ns & ns \\
\hline DIVMS, \%MS & 66,3 & 64,4 & 65,3 & 65,6 & 65,0 & 63,8 & 66,8 & 3 & $* *$ & ns & $*$ & $\dagger$ & $*$ & ns & ns & $\dagger$ \\
\hline CINZA, \%MS & 11,9 & 11,7 & 12,1 & 11,8 & 12,0 & 10,7 & 13,0 & 6 & $* *$ & ns & ns & ns & ns & ns & ns & ns \\
\hline $\mathrm{pH}^{2}$ & 5,12 & 5,07 & 4,96 & 4,99 & 5,11 & 5,19 & 4,91 & 4 & ns & $\dagger$ & ns & ns & * & ns & ns & - \\
\hline $\mathrm{CE}\left(\mu \mathrm{S} \mathrm{cm}^{-1}\right)^{2}$ & 1448 & 1442 & 1501 & 1459 & 1468 & 1201 & 1726 & 7 & $* *$ & ns & ns & ns & ns & ns & ns & - \\
\hline $\mathrm{N}-\mathrm{NH}^{3}, \% \mathrm{NT}^{2}$ & 10,1 & 14,3 & 12,9 & 11,7 & 13,2 & 17,1 & 7,8 & 54 & $* *$ & ns & ns & ns & $*$ & ns & ns & - \\
\hline
\end{tabular}

${ }^{1}$ Co-variável: para cada variável foi usado o valor da composição original da forragem como covariável, ${ }^{2}$ análises sem o uso de co-variáveis.

ENZ $(-)=$ sem enzimas fibrolíticas, ENZ $(+)=$ com enzimas fibrolíticas, ENZ+B = com enzimas fibrolíticas mais inoculante bacteriano, SE = sem emurchecimento, $\mathrm{EM}=$ emurchecida, $\mathrm{TP}=$ tamanho de partícula, $\mathrm{E}=$ enzima, $\mathrm{MS}=$ matéria seca.

ns Não-Significativo, * Significativo a $5 \%$ de probabilidade, ** Significativo a $1 \%$ de probabilidade, $†$ Significativo a $10 \%$ de probabilidade. 
verificada diferença significativa $(\mathrm{P}>0,10)$ do tamanho de partícula em relação à condutividade elétrica, observando-se o valor médio de $1.463 \mu \mathrm{S} \mathrm{cm}{ }^{-1}$. Os resultados obtidos contrariam a expectativa de verificar diferença entre os tratamentos e maiores valores de condutividade elétrica com a redução de tamanho de partícula. Esse fato foi constatado por Igarasi (2002), ao verificar o efeito significativo do tamanho de partícula em silagens de capim Tanzânia sobre a alteração da condutividade elétrica.

A inclusão de enzimas fibrolíticas ou de sua associação com inoculante bacteriano não alterou $(\mathrm{P}>0,10)$ a condutividade elétrica das silagens. Esse fato sugere que a adição de enzimas fibrolíticas e de enzimas associadas ao inoculante bacteriano não provocou o aumento da lise das células vegetais em silagem. Contudo, verificou-se em silagens emurchecidas que a condutividade elétrica aumentou de 1.201 para 1.726 $\mu \mathrm{S} \mathrm{cm}^{-1}$ em relação às não-emurchecidas. Portanto, os tratamentos com maiores teores de MS apresentaram maiores valores $(\mathrm{P}<0,01)$ para condutividade, demonstrando que houve maior lise celular nas forragens ensiladas com maiores conteúdos de MS. Esse fato poderia influenciar negativamente o padrão fermentativo das silagens emurchecidas, reduzindo componentes importantes no processo de fermentação de gramíneas, como a quantidade de carboidratos solúveis. No entanto, observando o teor de carboidratos solúveis (Tabela 5), constatou-se que tal afirmativa não procede. Em outro experimento, Castro (2002) também observou aumento significativo no valor da condutividade elétrica para os fenos de capim Tifton 85 com maior teor de MS (55 e 65\%).

Dessa forma, a inclusão de enzimas fibrolíticas associadas, ou não, ao inoculante bacteriano, por não apresentar efeito de aumento na condutividade elétrica, pode não estar necessariamente vinculada ao aumento de produção de efluente, por lise celular.

\subsubsection{Matéria seca e proteína bruta}

Para o teor de matéria seca das silagens, verificou-se que houve diferença $(\mathrm{P}<0,01)$ entre os tratamentos com silagens emurchecidas e não-emurchecidas (22 vs. 18\% de MS) e efeito $(\mathrm{P}<0,10)$ de enzimas (Tabela 5). Em comparação com a forragem, 
quando ensilada logo após o corte, o resultado do aumento no teor de matéria seca da silagem era previsto, por haver maior lixiviação de efluente, provocando aumento da concentração dos componentes. Contudo, foi constatado efeito contrário para as silagens emurchecidas, pois a matéria seca na forragem original foi reduzida de 25,7 para 22\% (Tabelas 1 e 5). Esse efeito pode ser atribuído à água, como produto resultante dos processos de respiração, fermentação e oxidação que ocorrem dentro do silo. Além disso, uma vez que foi verificada a produção de efluente em alguns tratamentos, provavelmente tenha ocorrido ruptura da célula vegetal e liberação do conteúdo celular, o que, também, indica o aumento da condutividade elétrica da silagem (Tabela 5). Todavia, caso o emurchecimento atingisse o ponto de $30 \%$ de matéria seca, seria mais provável que os teores de MS da forragem original e silagem se mantivessem praticamente constantes.

Em se tratando do teor de proteína bruta, foi verificado o efeito de emurchecimento $(\mathrm{P}<0,01)$, com as silagens não-emurchecidas apresentando menor teor de proteína bruta em relação às emurchecidas (Tabela 5); essa redução é mais acentuada ao se comparar com a forragem original.

$\mathrm{Na}$ forragem com a umidade original, 75 a $90 \%$ do $\mathrm{N}$ total encontra-se na forma de proteína, constituindo principalmente peptídeos, aminoácidos livres, amidas, nucleotídeos e clorofila. Com a maior intensidade de proteólise, cerca de 40 a $60 \%$ deste $\mathrm{N}$ poderá ser solubilizado em compostos nitrogenados não-protéicos durante a ensilagem (Pereira \& Reis, 2002; Jaster, 1995).

Observa-se ainda que condições de umidade e temperatura acima de $55^{\circ} \mathrm{C}$ são favoráveis à ocorrência de reações não enzimáticas entre os carboidratos solúveis e grupos aminas dos aminoácidos, resultando em compostos denominados produtos da reação de Maillard (Van Soest, 1994). A formação destes compostos, em silagens superaquecidas, pode promover diminuição acentuada na digestibilidade da proteína, estando associada a maiores teores de nitrogênio insolúvel em detergente ácido.

O emurchecimento proporcionou melhor qualidade fermentativa no material ensilado. Esse efeito está diretamente relacionado com a concentração de substratos e o aumento do potencial osmótico no material emurchecido, que favorece a proliferação de 
microrganismos desejáveis, bem como diminui a extensão da fermentação. Esses fatores ficam evidenciados pelo maior teor de carboidratos solúveis e pela menor produção de nitrogênio amoniacal no material emurchecido.

A adição de inoculante bacteriano associado a enzimas poderia diminuir a proteólise na silagem, porém, neste experimento, esses efeitos não foram comprovados ao se observar o teor de proteína bruta e a quantidade de nitrogênio amoniacal.

\subsubsection{Degradação da parede celular}

Quanto à fração fibrosa, tanto para FDN, FDA, celulose e hemicelulose, com exceção da lignina, verificou-se efeito significativo $(\mathrm{P}<0,01)$ do teor de matéria seca. As silagens obtidas de forragem emurchecida apresentaram os menores teores para fração fibrosa (Tabela 5), fato este que, provavelmente, pode estar relacionado com a possível hidrólise da fração fibrosa, provocada por enzimas presentes na própria planta durante o emurchecimento, e que pode ter sido acentuada com a adição das enzimas fibrolíticas. Foram verificados os valores médios para FDN de 71,6 e 72,0\% na matéria seca para forragem fresca e para forragem emurchecida, enquanto suas respectivas silagens apresentaram teores médios de 72,4 e 67,9\% de FDN. Assim, a redução da fração fibrosa associada aos maiores teores de carboidratos solúveis nas silagens emurchecidas promoveu incrementos na digestibilidade.

No que se refere ao efeito da adição das enzimas fibrolíticas sobre a fração fibrosa, foi observada diferença significativa para FDA, celulose, hemicelulose $(\mathrm{P}<0,01)$ e lignina $(\mathrm{P}<0,10) . \mathrm{Na}$ análise da FDN, houve apenas efeito $(\mathrm{P}<0,05)$ da interação do conteúdo de matéria seca e enzimas, conforme pode ser constatado na Figura 1. A adição de enzimas fibrolíticas, em silagens emurchecidas, proporcionou maior eficácia na redução do conteúdo de FDN, quando comparada à adição de enzimas fibrolíticas associadas ao inoculante bacteriano.

Nas silagens não-emurchecidas, houve aumento da concentração de FDN, e isso pode ter ocorrido em razão das perdas por efluente na fração da matéria seca, que passam a representar parte significativa dos componentes da silagem. Adicionalmente, a 
redução de carboidratos fermentescíveis contidos na silagem pode favorecer o aumento do teor de FDN (Mahanna, 1993). Segundo Van Soest (1994), a fração FDN da forragem nem sempre é reduzida na silagem tratada com enzimas.

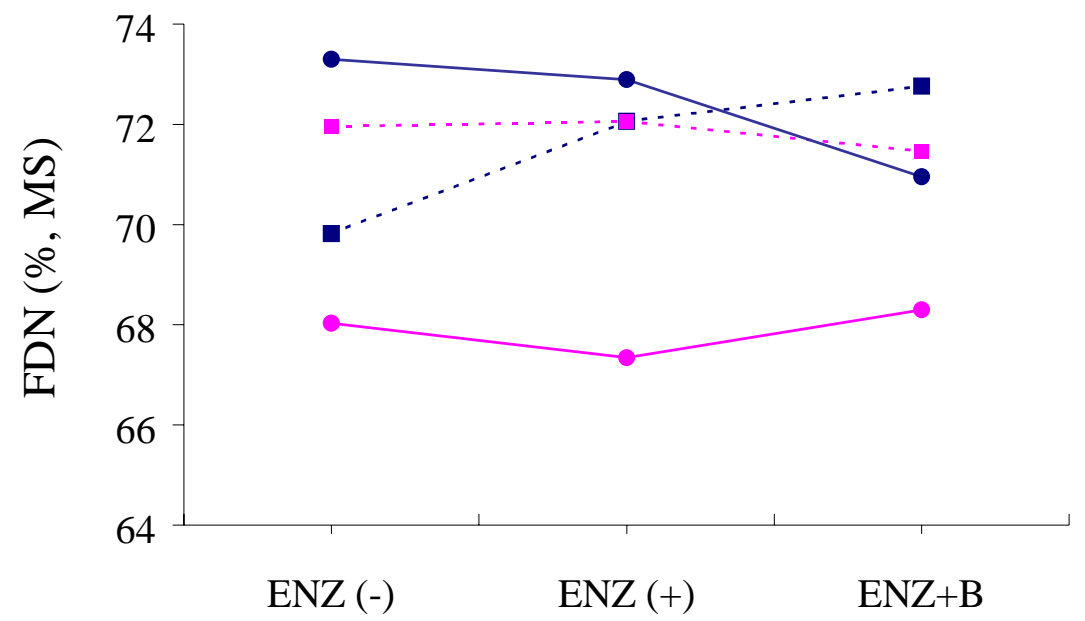

Efeito enzimas

$\cdots$ - - Forragem SE $\cdots$ - - Forragem EM $\longrightarrow$ Silagem SE $\longrightarrow$ Silagem EM

Figura 1 - Efeito de interação do conteúdo de matéria seca e enzimas fibrolíticas sobre o teor de FDN nas silagens de capim Tanzânia

Em silagens de alfafa emurchecidas e não-emurchecidas submetidas à ação de aditivos biológicos, ambas as silagens apresentaram redução do teor de FDN, com a aplicação de lactobacilos mais enzimas, e diminuição dos níveis de NIDN, com aplicação de enzimas. Conforme Rangrab et al. (1996), as enzimas presentes nesses produtos apresentariam sítios diferenciados de ação na degradação da parede celular.

A diferença na ação e na intensidade de degradação da parede celular por enzimas fibrolíticas também foi observada na avaliação de diferentes estádios de maturidade de gramíneas e leguminosas, segundo Aisan et al. (1997). Sheperd \& Kung Junior (1996) observaram, em silagens de milho ensiladas com diferentes estádios de maturidade, que a adição de enzimas (endoglucanase, exoglucanase, hemicelulase e ßglicosidase) foi responsável pela redução dos teores de FDN e FDA, porém a 
intensidade de redução foi maior em forragens com estádios mais avançados de maturidade. Esses dados parecem estar relacionados, principalmente, ao grau de lignificação da parede celular.

A hidrólise da hemicelulose, também, pode ocorrer durante o processo fermentativo (Van Soest, 1994); conforme observado na Figura 2, tanto no teor de hemicelulose quanto na relação hemicelulose/FDN houve redução dessas variáveis, independentemente do conteúdo de matéria seca. Assim, a partir dos dados obtidos no presente experimento, pode-se concluir que a intensidade da ação das enzimas fibrolíticas na degradação da fração fibrosa poderia estar mais associada ao conteúdo de matéria seca e ao sítio de ação específico do produto, que parece conter maiores atividades enzimáticas de hemicelulases e xilanases.

Verificou-se incremento do teor de FDA, comprovando a redução do teor de hemicelulose em ambas as silagens: emurchecidas e não-emurchecidas (controle e com enzimas fibrolíticas). Esse fato poderia ser explicado pelo aumento da fração celulose da forragem, uma vez que a fração de lignina apresentou poucas variações entre esses tratamentos, mantendo-se praticamente intacta. Paralelamente, na avaliação do teor de lignina, foi verificado efeito significativo $(\mathrm{P}<0,05)$ das interações entre conteúdo de matéria seca e enzimas (Figura 3 e Tabela 5) e entre conteúdo de matéria seca, tamanho de partícula e enzimas. Entretanto, analisando a interação em função da aplicação de enzimas, constatou-se para ambas as silagens, tanto com enzimas fibrolíticas isoladas ou associadas ao inoculante bacteriano, que os teores de lignina foram semelhantes entre si. Mesmo assim, é importante destacar que o efeito de redução da lignina em função da forragem original foi mais acentuado nas silagens emurchecidas submetidas à ação dos aditivos biológicos em associação.

Nas silagens de capim Tanzânia submetidas à ação de enzimas fibrolíticas associadas ao inoculante bacteriano, houve redução nos teores de praticamente todas as variáveis analisadas da fração fibrosa (FDN, FDA, hemicelulose, celulose), o que comprova os resultados positivos da adição do inoculante bacteriano associado às enzimas fibrolíticas sobre a degradação da fração fibrosa. 


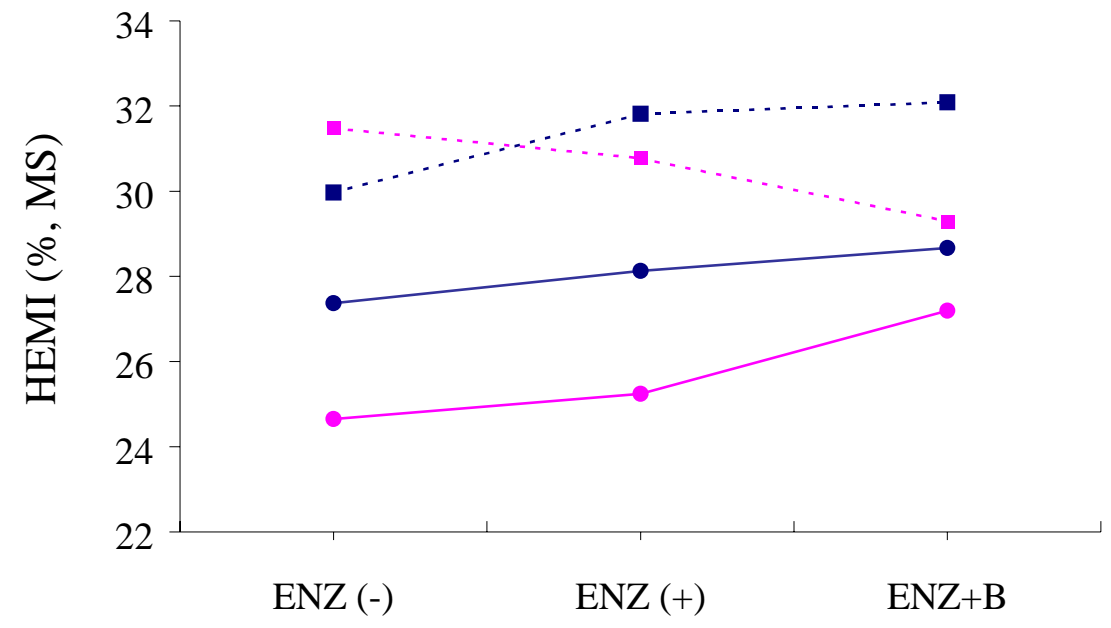

Efeito enzimas

- - Forragem SE $\cdots$ Forragem EM $\longrightarrow$ Silagem SE $\longrightarrow$ Silagem EM

Figura 2 - Efeito do conteúdo de matéria seca e de enzimas fibrolíticas sobre o teor de hemicelulose nas silagens de capim Tanzânia

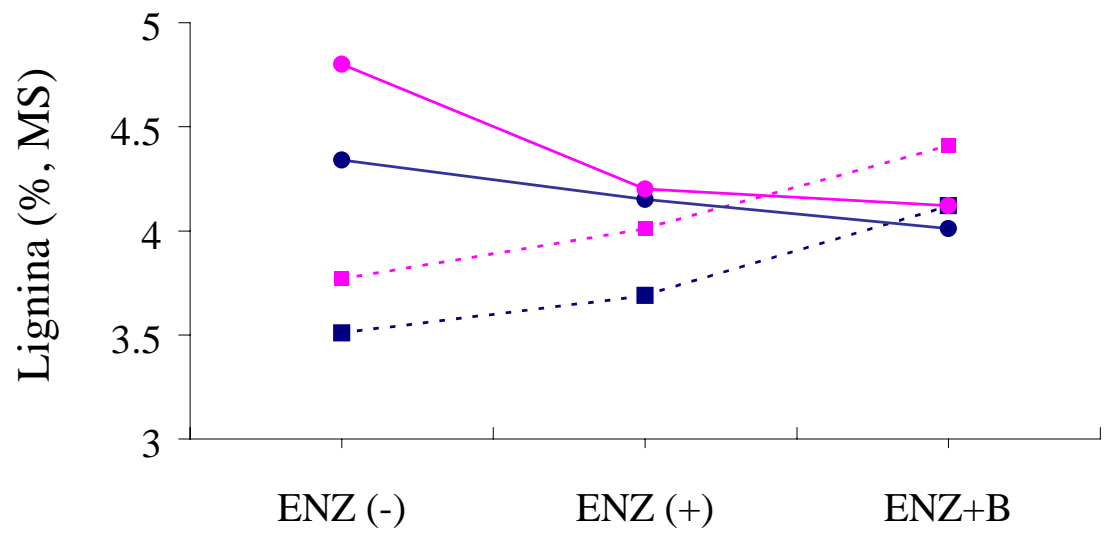

Efeito enzimas

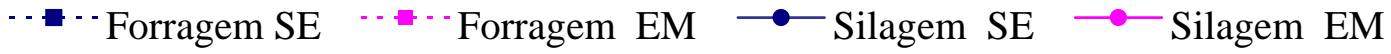

Figura 3 - Efeito de interação do conteúdo de matéria seca e enzimas fibrolíticas sobre o teor de lignina nas silagens de capim Tanzânia 


\subsubsection{Digestibilidade in vitro da matéria seca e teor de carboidratos solúveis}

Para a digestibilidade in vitro da matéria seca, foram observadas diferenças significativas $(\mathrm{P}<0,05)$ para os efeitos de conteúdo de matéria seca, de interação conteúdo de matéria seca e tamanho de partícula, de interação conteúdo de matéria seca e enzimas e $(\mathrm{P}<0,10)$ para o efeito de enzimas (Tabela 5$)$.

A maior digestibilidade da matéria seca em silagens emurchecidas pode ser atribuída ao fato de estas silagens apresentarem menor conteúdo da fração fibrosa. Quanto ao tamanho de partícula, pode-se concluir que as partículas menores provavelmente contribuíram para a melhoria da qualidade fermentativa da silagem, em conseqüência de maior compactação.

Apesar da maior degradação de alguns componentes da parede celular, causada pelas enzimas fibrolíticas ou associadas ao inoculante, esse fato não favoreceu o incremento da digestibilidade da matéria seca, como pode ser observado na Figura 4. Nadeau et al. (2000) também não verificaram aumento na digestibilidade tratada com enzimas fibrolíticas em silagens de alfafa e Dactylis glomerata L.

Associando o teor de lignina aos resultados da digestibilidade, poder-se-ia inferir que o fator preponderante na digestibilidade possa estar relacionado à concentração da lignina. Adicionalmente, o componente lignina sempre foi considerado como principal fator de limitação da digestão da parede celular da forragem, mesmo que, em alguns casos, devam ser consideradas sua distribuição e concentração dentro dos diversos tecidos celulares, bem como a proporção desses tecidos na forragem (Bush \& Burton, 1994). Segundo Jung \& Allen (1995), o estudo da ligação cruzada da lignina com os polissacarídeos via ácido ferúlico, também, seria importante em avaliações de digestibilidade da matéria seca. Neste experimento, observou-se redução do teor de lignina somente em silagens emurchecidas, tratadas com inoculante e enzimas fibrolíticas, porém não houve aumento significativo da digestibilidade da MS, reforçando a hipótese de que a concentração de lignina não é a única responsável pelas limitações da digestibilidade.

Mandebvu et al. (1999) também não observaram efeito da adição de enzimas 
fibrolíticas ou inoculante bacteriano sobre a digestibilidade da MS em silagens de capim Coastal Bermuda. Outros trabalhos com silagens de gramíneas, leguminosas ou silagens com dois tipos de forragens apresentaram efeitos inconsistentes sobre a digestibilidade da MS e digestão da fibra (Mandebvu et al., 1997a; Umana et al., 1991; Stokes, 1992;

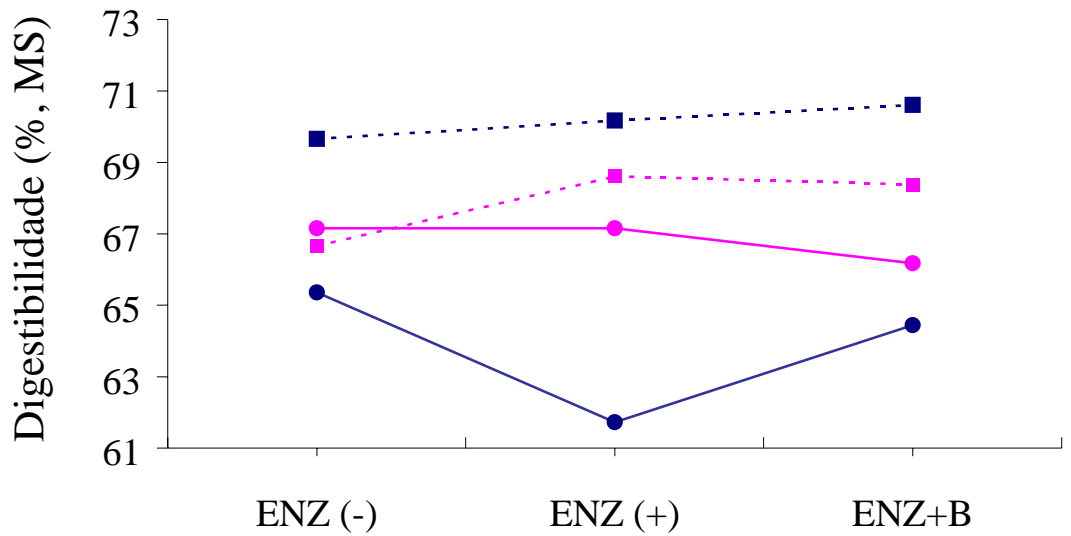

Efeito enzimas

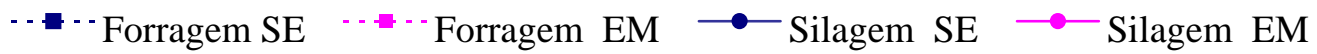

Figura 4 - Efeito de interação do conteúdo de matéria seca e enzimas fibrolíticas sobre a digestibilidade in vitro da MS nas silagens de capim Tanzânia

Sheperd \& Kung Junior, 1996). Contudo, Feng et al. (1996) e Harrison et al. (1994) relatam incrementos de digestibilidade da MS em forragens submetidas à ação de enzimas fibrolíticas.

No que se refere ao teor de carboidratos solúveis, observou-se efeito significativo $(\mathrm{P}<0,05)$ da adição de enzimas fibrolíticas e do conteúdo de matéria seca (Tabela 5 e Figura 5). Constatou-se que os maiores teores de carboidratos solúveis foram observados nas silagens emurchecidas com adição exclusiva de enzimas, apresentando média de 1,22\% na matéria seca. Esse efeito, provavelmente, deve estar associado à maior intensidade de degradação da fração de FDN observada nesses tratamentos. De forma complementar, os dados verificados por Nadeau et al. (2000) constataram aumento na concentração de açúcares à medida que se elevava a quantidade de celulase adicionada à alfafa e Dactylis glomerata L. 
Observou-se que as silagens emurchecidas apresentaram maiores concentrações de carboidratos solúveis que as não-emurchecidas, e as perdas de carboidratos solúveis foram mais intensas nas silagens não-emurchecidas. Na avaliação da forragem, houve perda de carboidratos solúveis com o emurchecimento. Segundo Moser (1995), uma das principais alterações durante o emurchecimento estaria nas perdas de carboidratos solúveis e ácidos orgânicos provocadas pela respiração da forragem.

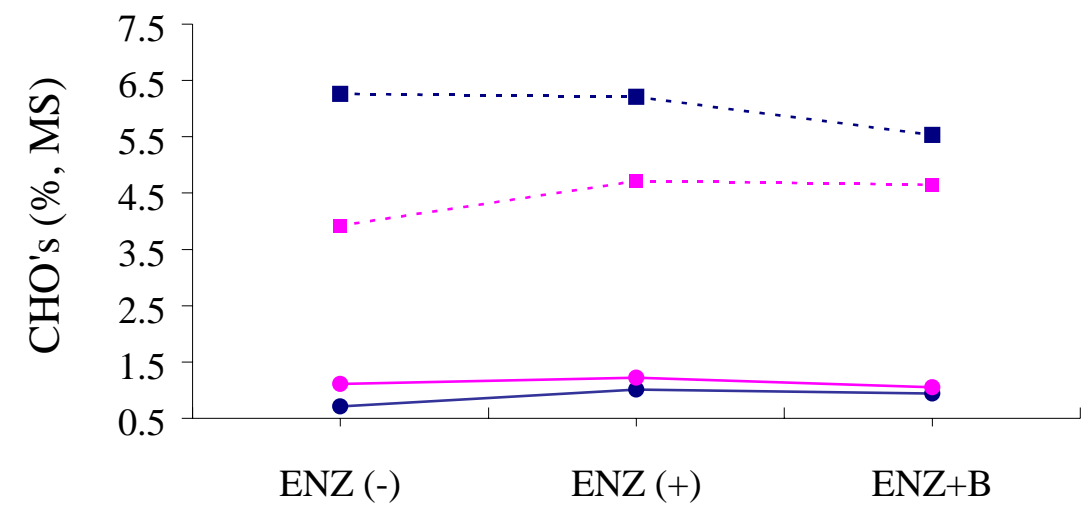

Efeito enzimas

$\cdots \cdot-$ Forragem SE $\cdots$ - Forragem EM $\longrightarrow$ Silagem SE $\longrightarrow$ Silagem EM

Figura 5 - Efeito do conteúdo de matéria seca e de enzimas fibrolíticas sobre o teor de carboidratos solúveis nas silagens de capim Tanzânia

No que se refere ao emurchecimento, os dados estão de acordo com os encontrados na literatura. Berto \& Mühlbach (1997) constataram que o emurchecimento da aveia preta (Avena strigosa Schreb.) resultou, em relação à forragem verde, em elevação dos teores de MS (15,3 para 31,2\%) e de carboidratos solúveis (2,9 para 3,3\%). Umana et al. (1991) registraram incrementos no teor de carboidratos solúveis em silagens emurchecidas de Coastal Bermuda.

Segundo Vilela (1998), as silagens com emurchecimento normalmente têm menores teores de ácido lático e altos teores de carboidratos solúveis, em conseqüência do aumento da pressão osmótica e da redução no poder-tampão da massa ensilada, proporcionando eficiente fermentação do material ensilado. As silagens com maior conteúdo de MS estabilizam em pH mais alto devido à menor atividade de bactérias do 
gênero Clostridium, que são sensíveis à pressão osmótica, preservando assim o teor de carboidratos solúveis (Woolford, 1984).

Poder-se-ia inferir que, no presente experimento, a adição de enzimas fibrolíticas melhorou a qualidade de fermentação da silagem, favorecendo a degradação de carboidratos estruturais da forragem, por fornecer açúcar adicional para a fermentação, porém a digestibilidade das silagens com enzimas não foi superior.

\subsubsection{Parâmetros da fermentação da silagem}

Para o pH, houve efeito significativo $(\mathrm{P}<0,05)$ da interação conteúdo de matéria seca e enzimas e do tamanho de partícula $(\mathrm{P}<0,10)$. Na análise do nitrogênio amoniacal foi verificado efeito significativo $(\mathrm{P}<0,01)$ de conteúdo de matéria seca e da interação matéria seca e enzimas $(\mathrm{P}<0,05)$, conforme pode ser observado na Tabela 5 .

Dos parâmetros avaliados sobre a fermentação da silagem, somente o pH alterou em função do tamanho de partícula; as silagens com partículas menores promoveram maior redução de $\mathrm{pH}$. Nesse contexto, pode-se afirmar que a redução de tamanho que partícula foi capaz de melhorar o processo de conservação, devido a uma maior compactação. Esse resultado está de acordo com os dados obtidos por Igarasi (2002), que, avaliando o tamanho de partícula, verificou o efeito significativo do pH; as silagens com menor tamanho foram as que apresentaram valores de $\mathrm{pH}$ inferiores àquelas com partículas maiores (4,39 vs. 4,50). Esse fato foi atribuído à melhor compactação decorrente da redução no tamanho de partícula, alterando a densidade da silagem (549,4 vs. 501,7 kg.m ${ }^{-3}$ ). Resultados similares foram encontrados por Aguiar et al. (2001), também com silagem de capim Tanzânia.

É importante destacar que a análise exclusiva de $\mathrm{pH}$ para a avaliação da qualidade da silagem não é recomendada. Nesse caso, a determinação do poder-tampão, ou seja, da resistência da forragem em alterar o pH (McDonald et al., 1991), associada ao fato de ser influenciado pelo teor de proteína e do amido e pela capacidade de absorção de água e da pressão osmótica da forragem (Giger-Reverdin et al., 2002), poderia fornecer razoável contribuição para discussão dos resultados. 


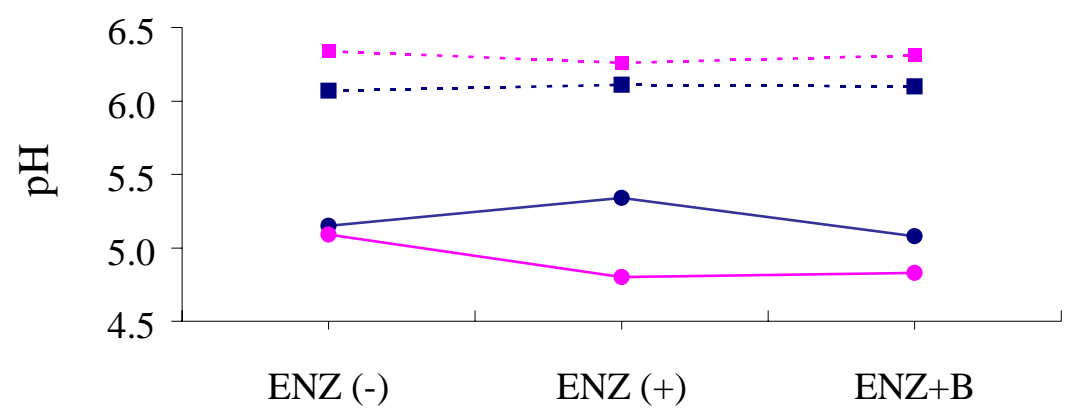

Efeito enzimas

$\cdots \cdot$ Forragem SE $\cdots \cdot$ Forragem EM $\longrightarrow$ Silagem SE $\multimap-$ Silagem EM

Figura 6 - Efeito de interação do conteúdo de matéria seca e enzimas fibrolíticas sobre o pH nas silagens de capim Tanzânia

Os dados de $\mathrm{pH}$, no presente experimento, estão próximos aos valores de $\mathrm{pH}$ observados para o capim Tanzânia emurchecido submetido a condições experimentais semelhantes (Figura 6). Aguiar et al. (2001), emurchecendo capim Tanzânia por 12 horas, reduziu o pH da silagem de 5,61 (19,99\% MS) para 5,55 (31,18\% MS). Igarasi (2002), com seis horas de emurchecimento de capim Tanzânia, elevou o teor de MS de 16,3 para 21,6\%, provocando o abaixamento do $\mathrm{pH}$ de 5,25 para 5,15.

Para adição de enzimas fibrolíticas isoladamente, foi observado efeito $(P<0,05)$ da interação do conteúdo de matéria seca e enzimas. O uso de enzimas fibrolíticas foi capaz de reduzir mais acentuadamente o pH nas silagens emurchecidas que em silagens não-emurchecidas, efeito este que talvez esteja mais relacionado ao emurchecimento do que à adição das enzimas fibrolíticas em si. Kuss (2001) não constatou efeito de enzimas fibrolíticas sobre os resultados de $\mathrm{pH}$ em silagens de azevém. Nadeau et al. (2002) verificaram que a ensilagem resultou em significante redução do $\mathrm{pH}$, porém a adição exclusiva de celulase reduziu ainda mais o pH em relação à silagem controle, tanto para a silagem de alfafa quanto para a Dactylis glomerata L.

Não houve efeito significativo para o uso de enzimas fibrolíticas associadas ao inoculante bacteriano, analisando a interação do conteúdo de matéria seca e enzimas 
sobre o pH. Existe a possibilidade de que a população bacteriana epifítica original seria suficiente na forragem, não promovendo, portanto, diferença nas médias do pH entre os tratamentos com e sem enzimas associadas ao inoculante em silagens emurchecidas e não-emurchecidas. Resultado semelhante foi obtido por Igarasi (2002), utilizando o mesmo inoculante bacteriano sem adição de enzimas fibrolíticas. Berto \& Mülbach (1997), ensilando aveia preta emurchecida submetida à ação tanto de inoculante quanto de enzimas, também não verificaram diferença significativa entre os valores de $\mathrm{pH}$ obtidos em relação ao controle. Magalhães (2002), recentemente, também não constatou alteração do $\mathrm{pH}$ em silagens emurchecidas de alfafa adicionando inoculante bacteriano $(4,96$ vs. 5,33$)$.

Contrariamente, os dados obtidos por Harrison et al. (1994) demonstraram incremento de ácido lático, redução de $\mathrm{pH}$ e dos componentes da parede celular com a combinação de bactérias láticas e enzimas fibrolíticas em silagens contendo diferentes espécies de gramíneas e leguminosas. De forma complementar, Stokes (1992) constatou que, nos tratamentos com enzimas ou com inoculantes, houve redução do $\mathrm{pH}$ da silagem, porém essa alteração foi realizada através de diferentes modos de ação. O autor sugere que a ação enzimática estaria mais relacionada ao poder-tampão, promovendo rápida redução de $\mathrm{pH}$, e a ação dos inoculantes bacterianos, mais associada à maior concentração de ácido lático e maior razão ácido lático/acético.

Assim, com base nos resultados obtidos, pode-se inferir que o uso de aditivos biológicos pouco influenciou o $\mathrm{pH}$ das silagens avaliadas, exceto para as silagens emurchecidas com adição de enzimas fibrolíticas, porém os níveis de pH estão dentro de uma faixa capaz de proporcionar uma adequada fermentação lática.

Para nitrogênio amoniacal, através da análise mais detalhada da interação conteúdo de matéria seca e enzimas (Figura 7), verificou-se que as silagens emurchecidas produziram menor quantidade de nitrogênio amoniacal que as nãoemurchecidas, proporcionando silagens com melhor qualidade fermentativa. Em relação aos outros tratamentos, os menores teores de nitrogênio amoniacal foram obtidos com a adição de enzimas fibrolíticas em silagens emurchecidas. 


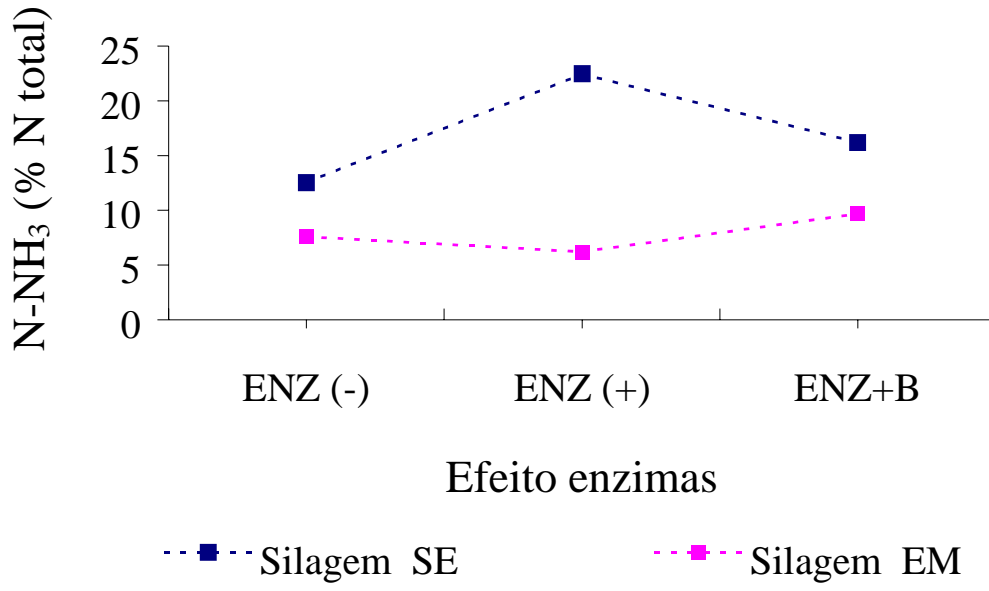

Figura 7 - Efeito de interação do conteúdo de matéria seca e enzimas fibrolíticas sobre o teor de nitrogênio amoniacal (\% N total) nas silagens de capim Tanzânia

Segundo Kung Junior (1997), as enzimas fibrolíticas têm melhorado a fermentação por estimular a produção de ácido lático, reduzindo o nitrogênio amoniacal e o pH. Nadeau et al. (2000) constataram redução na concentração do nitrogênio amoniacal com aplicação exclusiva de celulase em silagens de Dactylis glomerata L. e de alfafa em diferentes épocas de corte, mas a adição do inoculante (Lactobacillus plantarum e Pediococcus cerevisiae) foi mais eficaz na redução da concentração de nitrogênio amoniacal em silagens de Dactylis glomerata L. devido aos maiores teores de ácido lático, com conseqüente queda do $\mathrm{pH}$ e redução da proteólise. Adicionalmente, Chen et al. (1994) verificaram redução do teor do nitrogênio amoniacal em silagens de milho que receberam preparação bacteriana-enzimática (mistura de Lactobacillus plantarum e Pediococcus cerevisiae com celulase e xilanase). Contrariamente, Magalhães (2002) não observou efeito sobre o teor de nitrogênio amoniacal em silagens emurchecidas de alfafa utilizando somente o inoculante (Lactobacillus plantarum), sendo o mesmo observado por Igarasi (2002) em silagens de capim Tanzânia.

Ao observar os dados na literatura, pode-se concluir que o uso exclusivo de inoculante bacteriano (Lactobacillus plantarum) não deve ter promovido redução nos teores de nitrogênio, apesar de seu efeito potencial quando em associação a enzimas fibrolíticas. Esse fato talvez indique que a associação das enzimas fibrolíticas com esse 
tipo de inoculante bacteriano promova melhores resultados na degradação da parede celular que no padrão de fermentação das silagens, como pode ser observado nas silagens emurchecidas.

\subsubsection{Avaliação das perdas no processo fermentativo}

\subsubsection{Produção do efluente}

$\mathrm{Na}$ análise da produção de efluente, os resultados serão discutidos em função das silagens não-emurchecidas, uma vez que não foi verificada produção de efluente nos primeiros 90 dias nas silagens emurchecidas. Nestas últimas, somente após 90 dias de armazenamento foi observada produção esporádica de efluente em alguns tratamentos, tornando a análise estatística inviável.

A evolução do comportamento do fluxo do efluente para as silagens nãoemurchecidas encontra-se representada na Figura 8. Verificou-se que, nessas condições experimentais, mais de $80 \%$ do total de efluente foi produzido após a primeira semana de coleta. Loures (2000) observou que, em silagens de capim-elefante com 13\% de matéria seca, mais de 55\% do total de efluente foi produzido na primeira semana. Bastiman (1976) observou que 45\% do total de efluente foi produzido nos primeiros 20 dias de armazenamento em silagens com 25\% de matéria seca, aumentando para 90\% quando as silagens continham 16\% de matéria seca. Em revisão, Jones \& Jones (1995) destacam que, em silagens de azevém, $50 \%$ do total de efluente foi produzido na primeira semana e $80 \%$ nas primeiras seis semanas, sendo ainda verificada lenta e contínua drenagem de efluente no decorrer do armazenamento.

Nesse experimento foram utilizadas mangueiras para o escoamento, moldadas em 'e' vertical, no intuito de permitir a saída do efluente e, ao mesmo tempo, impedir a entrada de ar na massa ensilada. Contudo, ao longo do armazenamento, constatou-se que esse molde das mangueiras poderia estar dificultando o rápido escoamento do efluente, fato que, talvez, justifique a maior quantidade do total de efluente produzida 

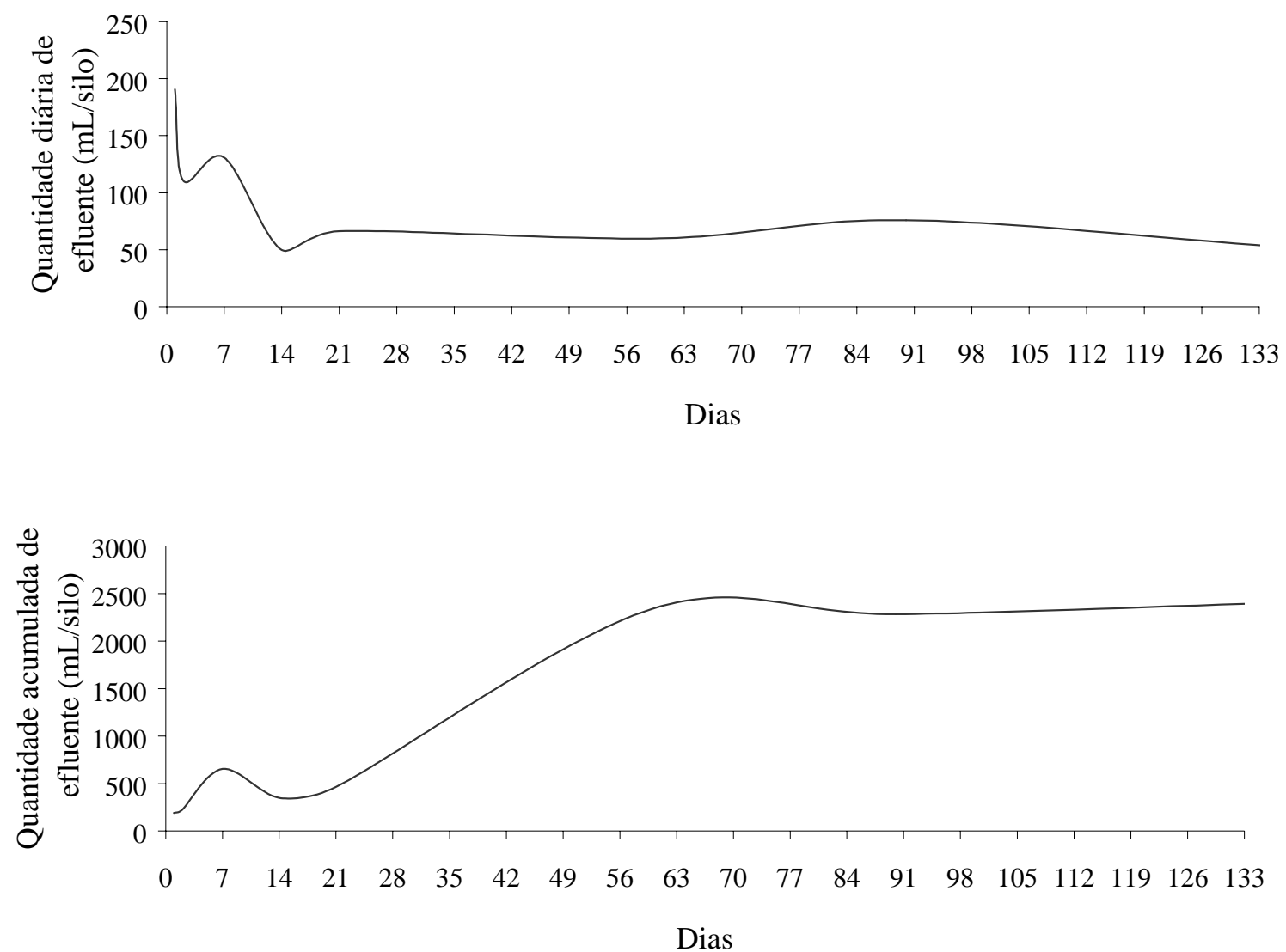

Figura 8 - Quantidade de efluente observada (mL) em um período de 136 dias de armazenamento, em silagens de capim Tanzânia emurchecido

somente após a primeira semana de armazenamento. Adicionalmente, verificou-se que a produção de efluente permaneceu lenta e contínua ao longo de todo o tempo de ensilagem.

Observou-se, ainda, que o pico de fluxo da produção de efluente ocorreu no primeiro dia de ensilagem. Loures (2000) constatou, para silagens de capim-elefante, pico de fluxo no segundo dia de armazenamento. Talvez essa diferença na produção inicial esteja relacionada à alteração da integridade estrutural e ao tempo em que se inicia a fermentação das forragens ensiladas (Pitt \& Parlange, 1987; Greenhill, 1964). 
$\mathrm{Na}$ análise da quantidade de efluente produzida durante os 136 dias, não foi verificado efeito do tamanho de partícula, da adição de enzimas ou das interações. No entanto, foi constatado efeito $(\mathrm{P}<0,01)$ do conteúdo de matéria seca sobre a produção de efluente. Observou-se que a quantidade total média de efluente produzida foi de 8,7 L em silagens não-emurchecidas e de $94 \mathrm{~mL}$ nas emurchecidas. O efeito do teor de matéria seca na produção de efluente é amplamente destacado na literatura; pelo fato de a produção de efluente ser diretamente proporcional à umidade da forragem ensilada, existem muitas equações para se estimar a quantidade de efluente produzido, ou seja, quanto mais úmida a forragem, maior produção de efluente (Bastiman, 1976; Rotz et al., 1993; Castle \& Watson,1973; Jones \& Jones, 1995; McDonald et al., 1991).

Na análise da produção total do efluente ao longo dos 136 dias foram verificados efeitos significativos de conteúdo de matéria seca $(\mathrm{P}<0,01)$, dia $(\mathrm{P}<0,01)$ e interação entre conteúdo de matéria seca e dia $(\mathrm{P}<0,01)$. Provavelmente, a ausência do efeito da adição das enzimas fibrolíticas associadas, ou não, ao inoculante na produção de efluente em silagens não-emurchecidas, se justifique em função da seqüência em que foram vedados os silos: sendo primeiramente os tratamentos controle, seguido daqueles contendo enzimas fibrolíticas e, por último, ao final da tarde, os tratamentos com enzimas fibrolíticas associadas ao inoculante bacteriano.

Analisando alguns trabalhos que utilizaram aditivos biológicos nas silagens, observa-se efeito positivo sobre a produção de efluente. Haigh (1996), avaliando o efeito de vários aditivos na fermentação e produção de efluente em diversos tipos de silagens de azevém-perene (Lolium perene), trevo-branco (Trifolium repens) ou azevém-italiano (Lolium multiflorum), não verificou efeito na produção de efluente em silagens que sofreram tratamento com inoculantes líquidos. Posteriormente, Haigh (1999) constatou o mesmo, utilizando inoculantes líquidos à base de Lactobacillus plantarum, enzimas e Pediococcus spp. Esses resultados concordam com os obtidos por Igarasi (2002), que também não verificou efeito da adição do inoculante bacteriano e da redução do tamanho de partícula sobre a produção de efluente em silagens de capim Tanzânia.

Entretanto, Harrison et al. (1994) relataram que o efeito de redução da digestibilidade em silagens com baixo teor de matéria seca, submetidas à ação de 
enzimas fibrolíticas, estaria associado ao aumento na produção de efluente. Muck \& Kung Junior (1997), ao se referirem à produção de efluente em cinco ensaios com gramíneas tratadas com enzimas fibrolíticas, observaram que houve aumento de produção de efluente e destacaram que a redução da deterioração aeróbia dessas silagens poderia compensar as perdas causadas por efluente. Segundo Sheperd et al. (1995), o excesso de hidrólise da parede celular causado pela adição de enzimas fibrolíticas poderia aumentar a produção de efluente em silagens de alfafa.

\subsubsection{Composição do efluente}

Os dados sobre a composição de efluente encontram-se na Tabela 6. Estão sendo apresentadas as informações obtidas de amostragem ocorrida aos 60, 90 e 136 dias do período de fermentação, uma vez que nessas datas foram conciliadas simultaneamente as análises de DBO, DQO, sólidos totais, sólidos totais fixos e $\mathrm{pH}$. Somente as silagens controle com partícula menor apresentaram produção de efluente no primeiro dia, enquanto silagens com enzimas fibrolíticas e partícula menor, no segundo dia, apresentaram produções mais relevantes após 21 dias de armazenamento.

Em relação aos dados obtidos para a DBO, houve efeito $(\mathrm{P}<0,01)$ do período de armazenamento; para DQO, houve efeito $(\mathrm{P}<0,10)$ da interação entre dias e enzimas; e a razão DQO/DBO apresentou efeito $(\mathrm{P}<0,01)$ de enzimas e dias. A DBO representa uma avaliação para medir as necessidades respiratórias de uma população microbiológica. Quando os microrganismos presentes na água (bactérias, protozoários) respiram, retiram do meio certa quantidade de oxigênio, provocando uma demanda deste gás. Adicionalmente, o efluente de silagens, que é rico em matéria orgânica e serve como fonte de alimento para esses microrganismos, apresentará maior demanda de oxigênio, por exaurir de forma significativa o oxigênio desse meio. Os resultados de efeito dos dias sobre os parâmetros que avaliam o grau de poluição do efluente inicialmente parecem estar mais relacionados com o intervalo entre as coletas realizadas durante o período de armazenamento da silagem. Esses intervalos foram de 39 (entre o $21^{\circ}$ e o $60^{\circ}$ dia), 30 (entre o $60^{\circ}$ e o $90^{\circ}$ dia) e 46 dias (entre o $90^{\circ}$ e o $136^{\circ}$ dia). 
Foram observados valores intermediários (entre o $90^{\circ}$ e o $136^{\circ}$ dia) para sólidos totais, sólidos totais fixos e DQO aos 60 dias. Contudo, o mesmo era esperado para os

Tabela 6. Composição do efluente da silagem de capim Tanzânia com diferentes teores de MS, tamanho de partícula e aplicações enzimáticas

\begin{tabular}{|c|c|c|c|c|c|c|c|c|c|c|c|c|c|}
\hline \multirow[b]{2}{*}{ Variáveis } & \multicolumn{3}{|c|}{ Enzimas fibrolíticas } & \multicolumn{3}{|c|}{ Dias (D) } & \multicolumn{7}{|c|}{ Efeitos e Interações $(\mathrm{P}>\mathrm{F})$} \\
\hline & $\begin{array}{c}\text { ENZ } \\
(-)\end{array}$ & $\begin{array}{c}\text { ENZ } \\
(+)\end{array}$ & $\begin{array}{c}\text { ENZ } \\
+\mathrm{B}\end{array}$ & 60 & 90 & 136 & $\mathrm{E}$ & ТP & $\mathrm{E} * \mathrm{TP}$ & $\mathrm{D}$ & $\mathrm{D} * \mathrm{E}$ & $\mathrm{TP} * \mathrm{D}$ & $\mathrm{D} * \mathrm{TP} * \mathrm{E}$ \\
\hline $\mathrm{DBO}, \mathrm{mg} \mathrm{L}^{-1}$ & 11809 & 11353 & 12244 & 8762 & 13528 & 13116 & ns & ns & ns & $* *$ & ns & ns & ns \\
\hline DQO, mg L ${ }^{-1}$ & 35892 & 43767 & 44148 & 42083 & 38908 & 42815 & ns & ns & ns & ns & $\dagger$ & ns & ns \\
\hline DQO/DBO & 3,26 & 4,11 & 4,07 & 5,06 & 2,95 & 3,39 & $* *$ & ns & ns & $* *$ & ns & ns & ns \\
\hline $\mathrm{ST}, \mathrm{mg} \mathrm{L}^{-1}$ & 32923 & 35281 & 34045 & 33999 & 30380 & 37868 & ns & ns & ns & $* *$ & ns & ns & ns \\
\hline STF, mg L ${ }^{-1}$ & 15830 & 18130 & 18112 & 16571 & 16050 & 19452 & ns & ns & ns & $* *$ & ns & ns & ns \\
\hline $\mathrm{pH}$ & 4,84 & 5,15 & 4,90 & 5,05 & 4,91 & 4,92 & $\dagger$ & ns & ns & $*$ & ns & ns & ns \\
\hline
\end{tabular}

ENZ (-) = sem enzimas fibrolíticas, ENZ $(+)=$ com enzimas fibrolíticas e ENZ+B $=$ com enzimas fibrolíticas mais inoculante bacteriano. ST = Sólidos totais. STF = Sólidos totais fixos.

ns Não-Significativo, * Significativo a $5 \%$ de probabilidade ** Significativo a $1 \%$ de probabilidade, † Significativo a $10 \%$ de probabilidade

outros parâmetros avaliados, uma vez que o intervalo de coleta foi de 39 dias. A DBO foi menor, indicando, portanto, menor quantidade de matéria orgânica no efluente e menor potencial de poluição. Apesar disso, a relação DQO/DBO foi elevada, o que dificulta a compreensão desse resultado, visto que a expectativa era de um valor bem menor.

Braile \& Cavalcanti (1993) destacam a importância em determinar as concentrações de DQO e de DBO para definir o tipo de tratamento, biológico ou físicoquímico, de uma água residuária. Dessa forma, quando essa relação apresentar valor inferior a 2, utiliza-se o tratamento biológico, e superior a 2, o tratamento físicoquímico.

A maior quantidade de matéria orgânica biodegradável foi verificada aos 90 dias, devido ao alto valor de DBO e à menor relação de DQO/DBO. Esse resultado 
talvez esteja relacionado com os menores valores de sólidos totais (matéria seca) e sólidos totais fixos (minerais). Assim, o menor intervalo de coleta do efluente (30 dias) resultou em maior quantidade de matéria orgânica, como açúcares, ácidos orgânicos, proteínas e outros compostos provenientes do material ensilado no efluente produzido. Portanto, pode-se inferir que, quanto menor o tempo de armazenamento da silagem, mesmo com elevado potencial de poluição, mais fácil será o tratamento do efluente.

Aos 136 dias, observou-se aumento da fração inerte no efluente, ou seja, aumento da quantidade de sólidos totais fixos, indicando, portanto, maior perda de minerais nas silagens em relação aos 90 dias. O maior intervalo de coleta poderia explicar a alta relação de DQO/DBO (superior a 2) e a maior quantidade de sólidos totais. Nesse caso, o maior tempo de armazenamento, além de contribuir para aumentar as perdas de nutrientes por efluente, tornou necessário o tratamento físico-químico desse efluente, com maiores custos, em razão da necessidade de aquisição e aplicação de produtos químicos.

Quanto aos valores médios observados, durante o período de armazenamento, de DBO (11.289 mg L ${ }^{-1}$ ), DQO (36.279 mg L ${ }^{-1}$ ), DQO/DBO (3,35), pH (4,9), sólidos totais (34.395 $\mathrm{mg} \mathrm{L}^{-1}$ ) e sólidos totais fixos $\left(16.533 \mathrm{mg} \mathrm{L}^{-1}\right)$, todos estão dentro da amplitude aceita na literatura para efluente de silagens de gramíneas. McDonald (1981) verificou que a DBO variava na literatura de 40.000 a $90.000 \mathrm{mg} \mathrm{L}^{-1}$, enquanto Jones \& Jones (1992), citados por Galanos et al. (1995), registraram valores entre 10.000 e $110.000 \mathrm{mg} \mathrm{L}^{-1}$ e Loures (2000) observou o valor médio de aproximadamente 31.000 mg $\mathrm{L}^{-1}$. Portanto, mesmo com o valor obtido de DBO não tão elevado quanto os encontrados em diversos trabalhos, ainda assim representa um alto valor, visto que a legislação brasileira estipula valores de DBO e DQO de, no máximo, 60 e 90 mg L ${ }^{-1}$, respectivamente para os esgotos e dejetos lançados em cursos de água ou rios (COPAM, 1986; FEAM, 1998).

Os valores de DQO, relação DQO/DBO, pH e sólidos totais foram mais elevados que os obtidos por Loures (2000), provavelmente em razão da diferença entre os períodos de avaliação durante o armazenamento da silagem. Esta autora estudou a produção de efluente na primeira semana de armazenamento e, nesse experimento, os 
dados foram analisados até a abertura do silo, ao $136^{\circ}$ dia. Observa-se que existe um grande efeito dos dias de armazenamento e do grau de poluição do efluente; à medida que se aumenta o período de armazenamento da silagem, o efluente torna-se cada vez menos biodegradável, com uma fração mais inerte e com maior potencial de poluição. Portanto, considerando os impactos ao meio ambiente, armazenar silagens com maior teor de umidade sem infra-estrutura adequada por longos períodos vem a ser uma prática desaconselhável, apesar de largamente aplicada.

Em relação aos efeitos das enzimas, eles foram significativos para a relação DQO/DBO $(\mathrm{P}<0,05)$ e o $\mathrm{pH}(\mathrm{P}<0,10)$. A hidrólise da fração fibrosa com a ação das enzimas fibrolíticas favoreceu a produção de efluente com menor fração biodegradável, o que pode ser um critério importante a ser considerado na escolha do aditivo, quando utilizado isoladamente.

\subsubsection{Perdas por efluente e gases e taxa de recuperação de matéria seca}

$\mathrm{Na}$ relação de perdas gasosas, em \% MS, não houve efeito $(\mathrm{P}>0,10)$ do conteúdo de matéria seca, sendo semelhante tanto para as silagens com umidade original quanto para as emurchecidas (Tabela 7). Por conseguinte, ao contrário das expectativas, não foi observada em silagens com umidade original superioridade na produção de gás; apesar de terem apresentado elevados teores de nitrogênio amoniacal (Tabela 5), esse fato não favoreceu a maior incidência de fermentações indesejáveis.

As perdas por gases estão associadas ao tipo de fermentação ocorrida na ensilagem. Quando a fermentação é realizada predominantemente por bactérias homofermentativas, verifica-se redução nas perdas de MS. As maiores produções de gases estão associadas às bactérias heterofermentativas, enterobactérias, leveduras e bactérias do gênero Clostridium ssp. (Nussio et al., 2002; McDonald, 1981).

Não houve efeito significativo $(\mathrm{P}>0,10)$ de tamanho de partícula em relação à produção de gás (Tabela 7); assim, pode-se inferir que as perdas gasosas foram similares para os dois tamanhos de partículas. Aguiar et al. (2001) observaram menor produção de gás quando houve a redução do tamanho de partícula em silagens de capim Tanzânia; 
contudo, na amplitude de tamanhos de partículas similares aos do presente experimento, verificou-se que os autores, também, não encontraram efeito significativo, atendendo a hipótese de haver um limiar para tamanhos de partícula, a partir do qual as perdas

Tabela 7. Taxa de recuperação da MS, perdas por gases e efluente, em percentagem de matéria seca, nas silagens de capim Tanzânia com diferentes teores de MS, tamanho de partícula e aplicações enzimáticas

\begin{tabular}{|c|c|c|c|c|c|c|c|c|}
\hline \multirow[t]{2}{*}{$\begin{array}{c}\text { Variáveis } \\
\text { (\%MS) }\end{array}$} & \multicolumn{3}{|c|}{ Enzimas fibrolíticas } & \multicolumn{2}{|c|}{$\begin{array}{l}\text { Tamanho } \\
\text { de } \\
\text { partícula }\end{array}$} & \multicolumn{2}{|c|}{$\begin{array}{c}\text { Conteúdo } \\
\text { de MS }\end{array}$} & \multirow[t]{2}{*}{$\mathrm{CV}(\%)$} \\
\hline & ENZ(-) & $\operatorname{ENZ}(+)$ & $\mathrm{ENZ}+\mathrm{B}$ & $<$ & $>$ & SE & EM & \\
\hline Tx. Rec. MS & 72,7 & 78,7 & 76,3 & 77,3 & 74,6 & 72,3 & 79,5 & 13 \\
\hline Efluente & 3,29 & 2,40 & 2,01 & 2,56 & 2,58 & 5,11 & 0,02 & 46 \\
\hline \multirow[t]{3}{*}{ Gases } & 24,0 & 18,9 & 21,6 & 20,2 & 20,9 & 22,6 & 20,5 & 44 \\
\hline & \multicolumn{8}{|c|}{ Efeitos e Interações $(\mathrm{P}>\mathrm{F})$} \\
\hline & MS & $\mathrm{TP}$ & MS*TP & E I & MS*E & $\mathrm{TP} * \mathrm{E}$ & \multicolumn{2}{|c|}{ MS*TP*E } \\
\hline Tx.Rec.MS & $* *$ & ns & ns & ns & ns & ns & \multicolumn{2}{|r|}{ ns } \\
\hline Efluente & $* *$ & ns & ns & $*$ & $*$ & ns & \multicolumn{2}{|r|}{ ns } \\
\hline Gases & ns & ns & ns & ns & ns & ns & \multicolumn{2}{|r|}{ ns } \\
\hline
\end{tabular}

gasosas se intensificam, fato este anteriormente sugerido por Igarasi (2002). Apesar dos resultados obtidos quanto ao tamanho de partícula, Nussio et al. (2002) destacam que, mesmo não havendo redução da perda total de MS, a redução no tamanho de partícula seria importante, por representar redução do custo de produção, por determinar maior densidade da forragem e, por isso, menor custo de transporte e armazenamento.

A adição de inoculante bacteriano, isoladamente, apresenta resultados positivos na redução das perdas gasosas. Igarasi (2002) constatou que a adição de inoculante bacteriano proporcionou efeito significativo na redução de perdas em relação ao tratamento controle (3,86 vs. 4,83\%). Dados semelhantes foram obtidos por Cai et al. (2001), com cepas de L. plantarum, tanto em silagens de alfafa (6,3 vs. 4,1 L kg MS ${ }^{-1}$ ) quanto nas de azevém (5,0 vs. 3,7 $\mathrm{L} \mathrm{kg} \mathrm{MS}^{-1}$ ). No entanto, no que se refere à adição de 
enzimas fibrolíticas isoladas ou associadas ao inoculante bacteriano, não houve efeito $(\mathrm{P}>0,10)$ significativo na redução de produção de gases.

Para a taxa de recuperação de matéria seca, observou-se efeito $(\mathrm{P}<0,01)$ significativo do conteúdo de matéria seca (Tabela 7). As silagens emurchecidas apresentaram incrementos de 7,2 unidades percentuais da taxa de recuperação de matéria seca, em relação às não-emurchecidas.

Com relação às perdas de matéria seca por efluente em função dos resultados obtidos de produção de gases e taxa de recuperação de matéria seca, foi possível detectar o efeito significativo $(\mathrm{P}<0,05)$ da aplicação das enzimas fibrolíticas (Tabela 7). Assim, verificou-se que a aplicação de enzimas fibrolíticas foi capaz de reduzir as perdas de MS por efluente; essa redução foi ainda mais acentuada quando essas perdas eram associadas ao inoculante bacteriano.

Efeito significativo $(\mathrm{P}<0,05)$ também foi observado no conteúdo de matéria seca: as silagens não-emurchecidas apresentaram perdas de 5\% de MS, enquanto as emurchecidas praticamente não apresentaram perdas de MS por efluente (Tabela 7). Esse fato, portanto, confirma os relatos de Woolford (1984) sobre as perdas de MS da silagem pelo efluente, que envolvem valores de 5 a 10\%. Esse resultado confirma mais uma vez a importância do processo de emurchecimento sobre o controle de perdas em silagens de gramíneas.

\subsection{Conclusões}

Apesar de o menor tamanho de partícula estar relacionado com o aumento de perdas por efluente, parece haver um limiar para que isso ocorra, visto que essa evidência não se comprovou no presente experimento. A redução do tamanho de partícula, embora não tenha influenciado os parâmetros físicos das silagens, favoreceu de modo indireto o processo de fermentação, reduzindo o pH. Conseqüentemente, esse fato pode ter contribuído para aumentar a digestibilidade in vitro da matéria seca da forragem. Além disso, foi eficaz em evitar a plena aeração das silagens, devido à maior acomodação do material, garantindo maior estabilidade aeróbia. 
Adicionalmente, o emurchecimento também resultou em silagens de melhor qualidade, em virtude da redução das perdas e melhoria dos parâmetros fermentativos, o que vem enfatizar a importância dessa prática no processo de conservação de forragens associada à redução do tamanho de partícula.

A adição de enzimas fibrolíticas nas silagens promoveu redução da fração fibrosa, principalmente de hemicelulose, tanto em silagens emurchecidas quanto em não-emurchecidas, sendo sua eficiência mais acentuada nas emurchecidas. Todavia, não houve incremento na digestibilidade da matéria seca, indicando que a ausência de alteração na digestibilidade com a redução da fração fibrosa estaria associada às frações menos digestíveis da parede celular, como complexos de carboidrato-lignina.

A associação de enzimas fibrolíticas com inoculante bacteriano não promoveu incrementos significativos na degradação da fração fibrosa e no perfil de fermentação em relação à adição das enzimas fibrolíticas. De modo geral, resultou em silagens de boa qualidade.

As perdas por efluente foram maiores nas silagens não-emurchecidas, porém a adição de enzimas fibrolíticas associadas, ou não, ao inoculante bacteriano, contrariando as expectativas, não proporcionou incremento das perdas de matéria seca com a adição desses aditivos biológicos.

O efluente produzido pela silagem de capim Tanzânia apresenta elevado potencial poluidor, DBO de $11.289 \mathrm{mg} \mathrm{L}^{-1}$, e, portanto, merece ser tratado com devida atenção, uma vez que está praticamente 200 vezes acima do que é permitido pela legislação brasileira e do Estado de São Paulo, conforme o artigo 18 - Decreto 8468 Lei 997. Em vista dos resultados obtidos, recomenda-se evitar longos períodos de armazenamento das silagens, com vistas a reduzir as perdas de nutrientes e de MS por efluente.

As silagens de capim Tanzânia são susceptíveis às perdas cuja ocorrência e magnitude não são sincronizadas. Assim, a adoção de práticas de manejo direcionadas ao controle de perdas deverá considerar a associação de procedimentos e seus efeitos interativos. 


\section{USO DE ENZIMAS FIBROLÍTICAS E TEOR DE MATÉRIA SECA EM SILAGENS DE CAPIM TANZÂNIA NA DIGESTÃO DE NUTRIENTES, PARÂMETROS RUMINAIS E COMPORTAMENTO INGESTIVO EM BOVINOS DE CORTE}

\section{Resumo}

O presente estudo teve por objetivo avaliar o efeito do conteúdo de matéria seca da forragem (emurchecida ou não) e o uso de enzimas fibrolíticas aplicadas durante a ensilagem de capim Tanzânia (Panicum maximum, Jacq cv. Tanzânia) ou após a abertura do silo. Os tratamentos foram confeccionados da seguinte forma: A - forragem emurchecida sem aplicação de enzimas; B - não-emurchecida sem aplicação de enzimas; $\mathrm{C}$ - emurchecida com enzimas ( $2 \mathrm{~L} \mathrm{t}^{-1}$ de massa verde); $\mathrm{D}$ - não-emurchecida com enzimas; e $\mathrm{E}$ - não-emurchecida com enzimas (10 $\mathrm{L} \mathrm{t}^{-1}$ de massa verde), após a abertura do silo. Avaliou-se a composição bromatológica das silagens e o tamanho médio de partículas destas. Cinco novilhos da raça Nelore foram distribuídos ao acaso em delineamento do tipo Quadrado Latino 5 x 5, recebendo rações contendo 50\% de silagem na base de MS. Foram realizadas observações de comportamento ingestivo, consumo voluntário, parâmetros de fermentação e cinética ruminal e digestibilidade dos nutrientes. Os parâmetros de cinética de passagem de sólidos (2,23\% hora $\left.^{-1}\right)$ e de líquidos $\left(4,83 \%\right.$ hora $\left.^{-1}\right)$ foram similares para os tratamentos avaliados. O comportamento ingestivo dos animais não foi alterado com a elevação da concentração de MS da silagem, sendo observados os seguintes tempos (minutos dia ${ }^{-1}$ ) e taxas (min kg MSI ${ }^{-1}$ ) de ingestão de MS (247 e 24), de ruminação (426 e 43) e de mastigação (673 e 
67), respectivamente. As médias das concentrações molares totais dos ácidos graxos voláteis (109,62 mM) e de nitrogênio amoniacal (5,6 $\left.\mathrm{mg} \mathrm{dL}^{-1}\right)$, do fluido ruminal, não foram alteradas pelos tratamentos aplicados. Diante dessas observações, pode-se concluir que o emurchecimento da forragem e o uso de aditivo enzimático não resultaram em alterações significativas no comportamento ingestivo, nos parâmetros ruminais e na digestibilidade de nutrientes em animais.

\section{FIBROLYTIC ENZYMES AND THE DRY MATTER CONTENT OF TANZANIA GRASS SILAGE ON THE NUTRIENT DIGESTION, RUMINAL PARAMETERS AND INGESTIVE BEHAVIOR OF BEEF STEERS}

\section{Summary}

The present trial aimed to study the effects of forage wilting or the addition fibrolytic enzymes to the Tanzania grass (Panicum maximum, Jacq cv. Tanzania) during the ensiling process or after the silage unloading. Treatments consisted of: A - wilted forage without enzymes; B - fresh forage without enzymes; C - wilted forage with enzymes at ensiling ( $2 \mathrm{~L} \mathrm{t}^{-1}$ wet forage); $\mathrm{D}$ - fresh forage with enzymes at ensiling; $\mathrm{E}$ enzymes applied onto silage (10 L t ${ }^{-1}$ wet silage) 30 minutes before feeding (direct-fed). Silage samples were submitted to chemical analysis and screened for particle size measurements. Five ruminally cannulated Nellore beef steers were randomly assigned to a 5 x 5 Latin square design and fed 50\% silage TMR diets. Animal ingestive behavior, dry matter intake, ruminal fermentation and kinetics parameters and in vivo nutrient digestibilities were measured. The ruminal passage rate of solid $\left(2.23 \%\right.$ hour $\left.^{-1}\right)$ and liquid (4.83 \% hour ${ }^{-1}$ ) phases were similar for all treatments. The animal ingestive behavior measured as total time (minutes day ${ }^{-1}$ ) and rate (minutes DM kg-1) was not changed across silages DM concentration, averaging DM eating (247; 24), DM ruminating (426; 43) and DM chewing (673; 67), respectively. The molar concentration (109.62 mM) of total volatile fatty acids (VFA) and ammonia-N (5.6 mg dL ${ }^{-1}$ ) observed 
in ruminal fluid were similar across silages diets. According to the results it may be concluded that wilting Tanzania grass or the application of fibrolytic enzymes did not improve significantly either the animal ingestive behavior, ruminal parameters or the nutrient digestibilities.

\subsection{Introdução}

Geralmente, consideram-se como aditivos de silagens aquelas substâncias que podem ser adicionadas às forragens ensiladas para melhorar a fermentação ou reduzir perdas, podendo ser classificados em inibidores e estimuladores de fermentação. A utilização de enzimas na ensilagem visa aumentar a eficiência do processo fermentativo, favorecendo a atuação de microrganismos desejáveis, como as bactérias produtoras de ácido lático. As principais enzimas fibrolíticas utilizadas, como a hemicelulase, celulase, pectinase e xilanase, atuariam fornecendo açúcares simples às bactérias fermentadoras como fonte de nutriente, por meio da degradação de carboidratos complexos da parede celular (Muck \& Kung Jr, 1997).

Grande parte dos carboidratos das forragens está na forma de polissacarídeos

presentes na parede celular, que não são diretamente fermentados pela microbiota durante o processo de ensilagem. Quando há acúmulo de oligossacarídeos, estes passam a não ser utilizados pelas bactérias láticas, podendo, assim, favorecer a fermentação ruminal (Reis \& Jobim, 2000). Enzimas como a hemicelulase e a celulase degradam a hemicelulose em pentoses e a celulose em glucoses, respectivamente, aumentando o teor de açúcares na silagem e reduzindo o conteúdo de FDN e FDA; dessa forma, potencialmente, podem melhorar seu consumo e digestibilidade (Beauchemin et al., 1995).

Segundo Van Soest (1994), a eficiência da fermentação total do rúmen pode ser esperada como resposta ao aumento de disponibilidade de carboidratos solúveis, em virtude da liberação destes açúcares que podem permanecer na silagem.

$\mathrm{O}$ pH ótimo para ação das enzimas fibrolíticas geralmente difere do $\mathrm{pH}$ do líquido ruminal; e no caso das xilanases e celulases, a atividade catalítica ótima ocorre 
entre pH 6 e 8 (Fontes et al., 1995), enquanto o líquido ruminal apresenta valores de $\mathrm{pH}$ variando entre 5,5 e 7. Portanto, uma vez ingeridas, as enzimas exógenas poderão apresentar menor atividade fibrolítica. Por outro lado, a atividade das enzimas fibrolíticas, quando associada à partícula do alimento, é bem maior do que a ação degradativa do líquido ruminal sobre a fibra. Assim, é difícil estimar a contribuição de enzimas no aumento da atividade fibrolítica, ainda que sua atividade seja inferior à atividade enzimática do líquido ruminal.

A quantidade de enzima a ser utilizada depende da natureza do substrato, indicando a necessidade de determinar a taxa de aplicação adequada das preparações enzimáticas para o substrato específico. Segundo Beauchemin \& Rode (1996), a taxa de inclusão de enzimas exógenas em dietas de ruminantes varia de 0,01 a 1\% na ração, incrementando de 10 a 100 vezes a atividade fibrolítica por grama de alimento. Contudo, elevadas taxas de aplicação não devem aumentar, necessariamente, o desempenho individual do animal. A taxa ótima de aplicação difere entre produtos enzimáticos, uma vez que cada qual tem sua fórmula específica.

Em relação aos métodos de avaliação da eficácia dos aditivos enzimáticos, temse verificado que os resultados, utilizando os métodos in situ ou in vivo, nem sempre são semelhantes; os resultados in vivo têm-se apresentado mais satisfatórios. Beauchemin \& Rode (1996) destacam que a aplicação direta das enzimas no ambiente ruminal pode apresentar menor eficiência enzimática quando comparada à aplicação direta no fornecimento do alimento. Alguns autores sugerem que as enzimas fibrolíticas podem ser parcialmente protegidas da degradação ruminal devido à alteração conformacional provocada por forte ligação com o substrato, quando estas são aplicadas diretamente ao alimento fornecido (Fontes et al., 1995). Outras técnicas, como a de produção de gás in vitro, também podem ser consideradas viáveis para a avaliação de eficiência enzimática.

Em alguns trabalhos, a aplicação de aditivos enzimáticos (celulase) no início da ensilagem permitiu aumentar a degradação do tecido de parênquima em alfafa (Medicago sativa) e Phleum pratense L., reduzindo as frações de FDN, FDA, hemicelulose e celulose, porém isso não representou necessariamente aumento na digestibilidade ruminal (Ishida et al., 2001; Aniwaru et al., 2001). 
Atualmente, são encontrados diversos trabalhos sobre aplicação de enzimas fibrolíticas em silagens, contudo as inúmeras variações quanto à padronização das preparações enzimáticas e formas de aplicação proporcionam resultados inconsistentes. Dessa forma, tem sido difícil avaliar e comparar o efeito das enzimas na fermentação da silagem e no desempenho de animais. O objetivo deste trabalho foi identificar a ação das enzimas fibrolíticas em dietas de ruminantes, bem como seu efeito no comportamento ingestivo, na degradação ruminal e na digestão de nutrientes.

\section{2 Material e métodos}

\section{2.1 Local do experimento}

O trabalho foi conduzido no Departamento de Zootecnia da Escola Superior de Agricultura “Luiz de Queiroz” (ESALQ-USP). As análises químico-bromatológicas foram realizadas no Laboratório de Bromatologia, pertencente ao mesmo Departamento.

\subsubsection{Forragem, animais utilizados e período experimental}

O capim Tanzânia foi colhido aos 45 dias de crescimento vegetativo, nos dias 31 de janeiro, 1 e 4 de fevereiro de 2002. Durante a ensilagem, a solução de enzimas fibrolíticas foi misturada à forragem, utilizando pulverizador manual, com volume de 7 L, da marca Coastal ${ }^{\circledR}$. Segundo a recomendação do laboratório Biotal Limited ${ }^{\circledR}$ (http://www.kfi4u.com/biotal_inoculants.htm), $150 \mathrm{~g}$ de enzimas fibrolíticas foram diluídos em 100 L de água destilada; 2 L desta solução foram aplicados por tonelada de massa verde do capim picado, sendo a taxa de aplicação de 2 mL de solução enzimática por quilo de forragem. Para aplicações no momento da alimentação do animal, $150 \mathrm{~g}$ da preparação enzimática foram diluídos em $500 \mathrm{~L}$ de água destilada e $10 \mathrm{~L}$ desta solução aplicados por tonelada de silagem, em uma taxa de aplicação de $10 \mathrm{~mL}$ de solução por quilo de forragem, 30 minutos antes do fornecimento da silagem aos animais. Em ambos 
os casos a aplicação se deu através de pulverização de baixa pressão, utilizando bicos do tipo cone cheio, regulado para geração de névoa fina.

As silagens foram produzidas em silos do tipo poço, com aproximadamente 2 metros de diâmetro e 6 metros de profundidade, cobertos e revestidos de alvenaria.

Os tratamentos experimentais foram distribuídos nos seguintes grupos:

> Tratamentos sem aplicação de enzimas fibrolíticas:

- A - forragem de capim Tanzânia emurchecido;

- B - forragem de capim Tanzânia sem emurchecimento.

Tratamentos com aplicação de enzimas fibrolíticas no momento da ensilagem:

- C - forragem de capim Tanzânia emurchecido;

- D - forragem de capim Tanzânia sem emurchecimento.

Tratamentos com aplicação de enzimas fibrolíticas no momento da alimentação do animal:

- E - forragem de capim Tanzânia sem emurchecimento.

As silagens permaneceram armazenadas por 62 dias. O período experimental foi iniciado no dia 8 de abril de 2002, com duração de 70 dias, subdividido em cinco períodos de 14 dias, sendo sete dias para adaptação dos animais às rações e sete para coleta de amostras.

Nesse experimento foram utilizados cinco bovinos machos castrados da raça Nelore, com peso médio inicial de 454 kg, portadores de cânulas ruminal e duodenal. Os animais foram distribuídos ao acaso, de acordo com a aleatoriedade obtida por um programa estatístico (Brown, 2001), em um galpão coberto contendo baias individuais de 1,06 metro de largura, com comprimento ajustável de acordo com o tamanho do animal, providas de comedouro, bebedouro automático e piso emborrachado.

As rações experimentais foram formuladas segundo o NRC (1996), prevendo taxa de ganho de peso de $920 \mathrm{~g} \mathrm{dia}^{-1}$. No início de cada período experimental, foram oferecidos aos animais $9 \mathrm{~kg}$ de MS dia $^{-1}$, seguidos de quantidades crescentes da ração, 
de acordo com o aumento do consumo diário até sua estabilização.

Antes de iniciar o experimento, aplicou-se injeção intramuscular de complexo vitamínico (ADE). Os animais foram pesados no início, meio e final do período experimental.

\subsubsection{Preparo, coleta de amostras e condução do experimento}

As rações foram fornecidas ad libitum, duas vezes ao dia (8 e 17 horas), permitindo-se $5 \%$ de sobras, caso estas ocorressem. A quantidade total de silagem destinada aos animais foi retirada do silo-poço pela manhã, sendo fornecidos $70 \%$ da ração às 8 horas e os 30\% restantes, às 17 horas. Portanto, a silagem fornecida à tarde permaneceu armazenada em baldes de plástico até o momento do uso, devidamente compactada para proporcionar exclusão do ar entre partículas. As sobras foram mensuradas todas as manhãs, para ajuste e avaliação do consumo de matéria seca. A amostragem diária das silagens e sobras foi realizada considerando-se sempre $5 \%$ do total, para formação de uma amostra composta ao final de cada período de coleta, que, posteriormente, foi acondicionada em sacos plásticos e armazenada em congelador ($20^{\circ} \mathrm{C}$ ), para posteriores análises laboratoriais.

No primeiro dia de coleta, foram avaliadas as atividades de comportamento ingestivo dos animais a cada 5 minutos, por 24 horas, registrando-se a freqüência de ingestão de água, ruminação, ingestão de alimento e ócio. No terceiro dia de coleta, amostras de fluido ruminal foram coletadas diretamente do rúmen, antes da alimentação matinal, e a cada duas horas, após o fornecimento da ração.

No quarto dia de cada período de avaliação, antes da alimentação da manhã, 100 gramas de amostras das silagens marcadas com cromo mordente e sacos de náilon foram inseridos no rúmen de cada animal, para determinar a taxa de passagem de sólidos da digesta e para a avaliação da degradação ruminal. Simultaneamente, para determinar a taxa de passagem da fase líquida, $1 \mathrm{~L}$ de solução contendo $3 \mathrm{~g}$ de Co-EDTA foi introduzido no rúmen. Nesse mesmo dia, também se iniciou a amostragem de fezes coletadas no reto. 
Nos dias 4, 5, 6 e 7 de cada período de coleta, foi realizada a coleta total de fezes, sendo estas quantificadas às 8 e 20 horas, e 5\% do total foi homogeneizado e amostrado, para constituir uma amostra composta do tratamento no período.

\subsubsection{Análises laboratoriais}

Ao final dos períodos de coleta, as amostras de silagem, concentrado e sobras armazenadas foram descongeladas, secas em estufa de circulação de ar forçada a $60^{\circ} \mathrm{C}$ por 72 horas, moídas em tamanhos de partículas de $1 \mathrm{~mm}$ e, posteriormente, submetidas às seguintes análises químico-bromatológicas: MM, extrato etéreo (EE) (AOAC, 1990); FDN, FDA, lignina segundo Van Soest et al. (1991) e MS (Silva, 1990).

Para as análises de carboidratos solúveis e nitrogênio amoniacal, foram preparados extratos aquosos da silagem, conforme Kung Junior et al. (1984), e armazenados em freezer. Posteriormente, para análise de carboidratos solúveis, foi utilizada a metodologia proposta por Dubois et al. (1956); para nitrogênio amoniacal, seguiu-se o método colorimétrico descrito por Okuda et al. (1965), adaptado para ser utilizado em placas de microtúbulo com mensuração em Colorímetro - Elisa Reader (absorbância de 630 nanômetros).

A determinação de nitrogênio foi obtida através da combustão da amostra segundo o método de Dumas, utilizando-se um auto-analisador de nitrogênio da marca LECO $^{\circledR}$, modelo FP-528 (Wiles et al., 1998). O teor de nitrogênio foi multiplicado pelo fator 6,25 para o cálculo da PB. As frações FDN e FDA foram determinadas em duplicata por amostra, utilizando-se o equipamento "Fiber Analyser Ankon 2000". A lignina foi obtida através do método LDA (lignina em detergente ácido), pelo uso de

solução de ácido sulfúrico a 72\%, após a determinação de FDA, utilizando o equipamento “Daisy Incubator Ankon”. A fração hemicelulose foi obtida pela diferença entre FDN e FDA, e a celulose, pela diferença entre FDA e lignina.

A estratificação de partículas nas amostras de silagens foi realizada segundo adaptação da metodologia das peneiras do “Penn State Particle Size Separator”, proposta por Lammers et al. (1996), através da avaliação da percentagem de material retido em 
orifícios com diâmetro de 38 mm (peneira 1), entre 38 e 19 mm (peneira 2) e 19 a 7,9 $\mathrm{mm}$ (peneira 3) e inferior a 7,9 $\mathrm{mm}$.

A determinação da condutividade elétrica da silagem (CE) foi feita segundo metodologia proposta por Kraus et al. (1997), com a utilização de um condutivímetro $\left(\mu \mathrm{S} \mathrm{cm}{ }^{-1}\right)$, CD-20 Digimed ${ }^{\circledR}$.

\subsubsection{Comportamento ingestivo}

O comportamento ingestivo foi avaliado por um período de 24 horas, por observadores previamente treinados para a detecção de todas as atividades estabelecidas para este parâmetro. Na tentativa de eliminar o efeito da luminosidade sobre o comportamento animal, mantiveram-se apagadas as luzes do galpão, no período noturno. Com auxílio de lanterna, a luz foi direcionada indiretamente sobre a cabeça dos animais, a fim de realizar as observações previstas no experimento.

A metodologia aplicada para avaliação do comportamento ingestivo dos animais foi baseada em trabalho proposto por Maekawa et al. (2002). Para efeito de análise do comportamento, foi necessário transformar as medidas realizadas a cada intervalo de cinco minutos para um minuto de observação. Em vista disso, multiplicouse o tempo total de ingestão de alimentos e água, ruminação e ócio por cinco. O tempo de mastigação foi determinado somando-se o tempo de ingestão do alimento com o tempo de ruminação. Assim, para efeito de cálculo, o período de 24 horas de observação foi transformado em minutos (1.440 min).

Os cálculos das taxas de ingestão, ruminação e mastigação da MS foram estimados pelo quociente entre a quantidade média de matéria seca ingerida (kg) e o tempo, em minutos do período, em cada tratamento avaliado. As taxas de ingestão, ruminação e mastigação da FDN foram estimadas pela multiplicação das respectivas taxas pela concentração de FDN efetivamente ingerida pelos animais. 


\subsubsection{Parâmetros ruminais}

As amostras de líquido ruminal foram tomadas diretamente de quatro pontos distintos, da região ventral do rúmen. A digesta foi filtrada em pano de algodão dobrado em duas camadas, em seguida a parte sólida foi devolvida ao rúmen, e imediatamente o líquido ruminal foi homogeneizado e o $\mathrm{pH}$ mensurado através de leitura direta com potenciômetro digital (Digimed ${ }^{\circledR}$ TE-902).

Após a mensuração do $\mathrm{pH}$, uma alíquota de aproximadamente $50 \mathrm{~mL}$ foi transferida para dois frascos distintos armazenados em congelador $\left(-20^{\circ} \mathrm{C}\right)$, para posterior determinação de nitrogênio amoniacal $\left(\mathrm{N}-\mathrm{NH}_{3}\right)$ e concentração molar de ácidos graxos voláteis (AGV). Após o descongelamento, coletou-se uma alíquota do líquido ruminal, seguindo-se centrifugação a 12.000 x g, $4^{\circ} \mathrm{C}$, durante 20 minutos. A fração sobrenadante foi utilizada para a determinação de $\mathrm{N}-\mathrm{NH}_{3}$, de acordo com o método colorimétrico descrito por Chaney \& Marbach (1962) e adaptado para ser utilizado em placas de microtúbulo, e, posteriormente, mensuração em Colorímetro Elisa Reader (absorbância de 550 nanômetros).

Para determinação dos AGVs, $4 \mathrm{~mL}$ da amostra do líquido ruminal foram centrifugados a $12.000 \mathrm{x} \mathrm{g}$, a $4^{\circ} \mathrm{C}$, durante 60 minutos, retirando-se uma alíquota de 0,8 $\mathrm{mL}$ do sobrenadante. Depois, foram adicionados $0,2 \mathrm{~mL}$ de ácido metafosfórico e 0,1 mL do padrão interno à alíquota do sobrenadante do fluido ruminal, para determinação da concentração molar de AGVs, conforme Palmquist \& Conrad (1971).

Utilizou-se o cromatógrafo líquido gasoso, CLG (Hewlett Packard ${ }^{\circledR}$ 5890, series II), equipado com HP Integrator 3396, série II (Hewlett Packard Company ${ }^{\circledR}$, Avondale, PA). Como padrão interno, foi utilizada a solução do ácido 2-etilbutírico, composta por $10 \mathrm{~mL}$ de álcool etanol, 1,16 g de ácido 2-etilbutírico e $30 \mathrm{~mL}$ de água deionizada. O gás de arraste e os comburentes foram nitrogênio, hidrogênio e oxigênio, respectivamente, nas vazões de 20,30 e $400 \mathrm{~mL} \mathrm{~min}^{-1}$. As temperaturas do injetor, do detector e da coluna foram de 150, 190 e $115^{\circ} \mathrm{C}$, respectivamente. Em cada frasco de leitura no cromatógrafo, foram adicionados $100 \mu \mathrm{L}$ do padrão interno, $800 \mu \mathrm{L}$ da mistura do sobrenadante elaborada após a centrifugação e $200 \mu \mathrm{L}$ de ácido 
metafosfórico a $25 \%$. As concentrações molares de AGVs foram corrigidas pelo fator de diluição de 1,25 , obtido pela diluição do ácido metafosfórico adicionado ao líquido ruminal.

\subsubsection{Avaliação da taxa de passagem de sólidos e líquidos}

Foram introduzidas, no rúmen, amostras de silagem de capim Tanzânia marcadas com cromo mordente, com o objetivo de se determinar a taxa de passagem dos sólidos da digesta ruminal, e uma solução de Co-EDTA, para determinação da taxa de passagem da fase líquida ruminal, de acordo com metodologia descrita por Udén et al. (1980).

Amostras de fezes foram coletadas diretamente do reto nos tempos de $0,6,12$, 18, 24, 30, 36, 42, 48, 54, 60, 66, 72, 78, 84 e 90 horas após a dosagem dos marcadores e, imediatamente, colocadas em estufa a $60^{\circ} \mathrm{C}$, com ventilação forçada, durante 72 horas.

A quantificação da concentração de Cr e Co-EDTA, nas fezes, foi realizada através da técnica analítica denominada fluorescência de raios $\mathrm{X}$ por dispersão de energia, utilizando-se o equipamento EDXRF (Energy Dispersive X-Ray Fluorescence), disponível no Laboratório de Instrumentação Nuclear da Divisão de Desenvolvimento de Métodos e Técnicas Analíticas e Nucleares, do CENA/USP.

Um grama de cada amostra das fezes, moído a $1 \mathrm{~mm}$, foi colocado em recipiente apropriado para análise por fluorescência de raios X (cubeta de plástico com

fundo de Mylar de 6,3 micrômetros de espessura), prensado a $2 \mathrm{t} \mathrm{cm}^{-2}$ e levado diretamente para análise, sem passar por nenhum tipo de pré-tratamento químico.

Para o cálculo da taxa de passagem, independentemente do marcador, foram utilizadas as concentrações de Cr e Co-EDTA (ppm) para cada animal, dentro de cada período e tratamento. A partir da maior leitura, determinou-se a porção linear da curva descrita pelos valores de $\ln [\mathrm{Co}]$ e $\ln [\mathrm{Cr}]$ e, desta, obteve-se o coeficiente angular (tg $\alpha$ $=(\Delta y / \Delta x) * 100)$ que representou a taxa de passagem $(K p)$ (Firkins et al., 1996). 


\subsubsection{Avaliação da digestibilidade aparente}

As estimativas da digestibilidade aparente da MS, matéria orgânica (MO), FDN, FDA e hemicelulose no trato total foram obtidas após quantificação total das fezes produzidas pelos animais, nos últimos quatro dias de cada período experimental. Com base na composição química das amostras de silagem, concentrado, sobras e fezes e da quantificação de cada nutriente na MS ingerida, deduzido o rejeitado do oferecido e excretado, calculou-se a digestibilidade aparente dos nutrientes. Para efeito de cálculo, a fórmula utilizada foi a seguinte (Equação 7):

$$
\text { Digestibilidade aparente }(\%)=\frac{(\text { Oferecido }- \text { Sobras })-\text { Fezes }}{(\text { Oferecido }- \text { Sobras })} \times 100
$$

Equação (7)

\subsubsection{Avaliação da degradabilidade in situ}

Para avaliação da degradabilidade de MS, FDN, FDA e hemicelulose, foram incubados, em triplicata, sacos de náilon de $7 \mathrm{~cm}$ por $14 \mathrm{~cm}$ de comprimento, com 6 gramas de silagem moída a 2 mm, por períodos de 6, 12, 24, 48 e 96 horas.

Os sacos de náilon foram selados e presos em argolas de metal por meio de borracha elástica; estas argolas, por sua vez, foram presas aos elos de uma corrente de 50 cm com o auxílio de mosquetes, de modo a evitar que os saquinhos ultrapassassem o limite do compartimento ruminal. Uma vez agrupados, foram previamente umedecidos por cinco minutos, conforme recomendação de Moore et al. (1987), e incubados em ordem reversa, sempre iniciada às 8 horas; eles foram retirados simultaneamente, visando reduzir as possíveis interferências da microflora ruminal no momento da lavagem.

Retirados do rúmen, os sacos de náilon foram lavados imediatamente em água corrente, até que esta se apresentasse limpa. Os saquinhos referentes ao tempo 0 foram 
lavados separadamente. Após a lavagem, foram levados para secagem em estufa de ventilação forçada a $60{ }^{\circ} \mathrm{C}$ por 72 horas, e o peso foi registrado para determinação da MS do resíduo.

Os dados das amostras incubadas foram processados utilizando o programa "Fit Curve” desenvolvido pela Rowett Research Institute, Aberdeen, Escócia (http://www.mluri.sari.ac.uk/IFRU/fcurve.html). O programa oferece os parâmetros do modelo de degradabilidade ruminal segundo Orskov \& McDonald (1979), entre outras informações. As degradabilidades potenciais in situ de matéria seca, FDN, FDA e hemicelulose foram calculadas de acordo com a Equação (8):

$$
\mathrm{Dg}=\mathrm{a}+\mathrm{b}\left(1-\mathrm{e}^{-\mathrm{ct}}\right)
$$

sendo:

Dg = degradabilidade potencial estimada, \%;

$\mathrm{a}$ = interseção da curva no tempo 0, podendo ser interpretada como fração rapidamente solúvel, \%;

b = fração insolúvel em água, mas potencialmente degradável, \%;

c = taxa de degradação da fração $\mathrm{b}$ por hora, $\% \mathrm{~h}^{-1}$;

e = logaritmo natural;

$\mathrm{t}$ = tempo de incubação, $\mathrm{h}$; e

$\mathrm{a}+\mathrm{b}=$ potencial de degradabilidade, $\%$.

A degradabilidade efetiva foi calculada pela equação de Orskov \& McDonald (1979) (Equação 9):

$\mathrm{DE}=\mathrm{a}+\left(\mathrm{b}\left(1 \times \mathrm{c}^{-\mathrm{c}+\mathrm{kp}}\right)\right.$

Equação (9)

sendo:

$\mathrm{Kp}$ = taxa de passagem

Para o cálculo da degradabilidade efetiva, foi considerada a taxa de passagem do alimento pelo rúmen determinada nas análises laboratoriais propostas neste experimento. 


\subsubsection{Delineamento experimental e análises estatísticas}

O delineamento experimental adotado foi o quadrado latino $5 \times 5$, com cinco tratamentos, cinco animais e cinco períodos de avaliação.

Os resultados obtidos foram analisados utilizando o programa estatístico GLM do SAS (2002). Para permitir comparações da composição bromatológica, digestão de nutrientes, comportamento ingestivo, ingestão de MS, digestibilidade aparente e degradabilidade in situ entre tratamentos e grupos de tratamentos, foram estabelecidos os seguintes contrastes ortogonais: entre tratamentos com emurchecimento e tratamentos sem emurchecimento (A, C vs. B, D e E), entre tratamentos com emurchecimento com e sem adição de enzimas (A vs. C), entre tratamentos sem emurchecimento com e sem adição de enzimas (B vs. D, E) e entre tratamentos sem emurchecimento com enzima fibrolítica aplicada na ensilagem e com enzimas fibrolíticas aplicadas 30 minutos antes de a silagem ser fornecida aos animais (D vs. E). Na comparação de médias entre tratamentos utilizou-se o teste de Tukey.

Os parâmetros ruminais de $\mathrm{pH}, \mathrm{AGV}$ e N-NH${ }^{3}$ foram analisados como medidas repetidas no tempo $(0,2,4,6,8,10,12,14,16,18,20,22$ e 24 horas) para cada tratamento, animal e período experimental; para isso, foi utilizado o PROC MIXED do mesmo programa estatístico.

As diferenças entre os tratamentos, para as diversas variáveis, foram analisadas adotando-se os níveis de significância de 1, 5 e 10\% de probabilidade.

\subsection{Resultados e Discussão}

\subsubsection{Avaliação das dietas experimentais}

\subsubsection{Granulometria}

A avaliação dos resultados, pelo teste $\mathrm{F}$, do percentual de material retido nas peneiras revelou diferença significativa $(\mathrm{P}<0,05)$ para a variável conteúdo de MS nas 
peneiras 1 e 3. Da amostra de forragem que não sofreu emurchecimento verificou-se, em dados de percentual médio, que 68\% ficaram retidos na peneira de $38 \mathrm{~mm}$; 22\%, na de $19 \mathrm{~mm}$; 8\%, na de 7,9 mm; e apenas 2\% apresentaram tamanho inferior a 7,9 mm. Já na proporção de forragem emurchecida: 52\% ficaram retidos na peneira de 38 mm; 25\%, na de $19 \mathrm{~mm}$; 18\%, na de 7,9 mm; e 5\% foram de tamanho de partícula inferior a 7,9 mm. Esses resultados foram semelhantes aos obtidos em silagens de capim Tanzânia por Igarasi (2002), ao considerar o somatório das duas peneiras superiores de maior diâmetro. Este autor, ao utilizar a metodologia de caracterização do tamanho de partículas, proposta por Lammers et al. (1996), constatou que ela não foi satisfatória para estratificar a forragem picada, uma vez que 79,9\% da amostra foi retida na peneira de diâmetro maior (19 mm). Analogamente, Coelho (2002) considerou que, no ato da agitação das peneiras, provavelmente não ocorreria desagregação suficiente para promover a passagem da forragem pelos orifícios, sugerindo que o tamanho dos orifícios para avaliação de partículas em gramíneas tropicais perenes devesse ser revisto. Portanto, o acréscimo de uma terceira peneira proporcionou resultados mais precisos em relação aos obtidos anteriormente com silagens de gramíneas tropicais, o que também foi confirmado por Mari (2003) avaliando a granulometria em silagens de Brachiaria brizantha cv. Marandu. No entanto, os resultados obtidos implicam que os percentuais das silagens retidas nas peneira de $38 \mathrm{~mm}$ ainda são excessivamente elevados; mesmo havendo maior precisão que na metodologia originalmente proposta, sugere-se que seja inserida mais uma peneira no protocolo da granulometria proposto por Lammers et al. (1996), para que sejam obtidos melhores resultados.

O tamanho de partícula da forragem é importante para o adequado funcionamento do rúmen. Portanto, a redução do tamanho de partícula da forragem pode diminuir o tempo de mastigação, causando decréscimo do volume de saliva produzida para tamponar o rúmen e, conseqüentemente, queda de pH. Segundo Mertens (1997), forragens com tamanhos de partículas inferiores a $40 \mathrm{~mm}$ reduzem em $80 \%$ a atividade de mastigação quando comparadas à forragem original, sem a picagem. Allen (1997), utilizando dados da literatura, avaliou a relação entre comprimento de partícula de forragem e tempo total de mastigação e verificou que aproximadamente $0,3 \mathrm{~cm}$ seria o 
tamanho de partícula a partir do qual não haveria alteração do tempo total de mastigação.

Avaliando as diferenças obtidas entre tamanhos de partícula das forragens emurchecida e não-emurchecida, verificou-se que quase $70 \%$ desta última se apresentavam com tamanho de partícula acima de $38 \mathrm{~mm}$ e que aproximadamente 50\% da primeira estava com tamanho de partícula acima de $38 \mathrm{~mm}$. Pode-se dizer que essa diferença não foi suficiente para promover alterações nos parâmetros ruminais e no tempo de mastigação, como poderá ser observado nas avaliações posteriores (Tabelas 11 e 13).

\subsubsection{Participação de ingredientes e composição bromatológica das rações}

Os teores dos nutrientes analisados nas amostras compostas da silagem de capim Tanzânia e do concentrado ofertados ao longo do período experimental e a composição bromatológica calculada das rações encontram-se nas Tabelas 8 e 9. As amostras de silagem e de concentrado foram analisadas separadamente para garantir maior precisão dos resultados, uma vez que a proporção volumoso:concentrado utilizada para formulação foi de aproximadamente 50:50.

A partir da avaliação dos resultados referentes ao teor de MS (Tabela 8), verificou-se que houve efeito significativo $(\mathrm{P}<0,01)$ entre as silagens que sofreram processo de emurchecimento durante cinco horas e as silagens sem emurchecimento. As condições ambientais apresentaram-se desfavoráveis, devido às chuvas de verão que ocorreram nos finais de tarde e, também, ao longo do período utilizado no enchimento do silo. Com isso, o teor de matéria seca esperado de 30\%, com cinco horas de emurchecimento, em decorrência das dificuldades apresentadas, não foi atingido. Os valores médios obtidos para as silagens emurchecidas e sem emurchecimento foram, respectivamente, de 24,06 e 21,24\% de MS. Observou-se, ainda, que a aplicação dos aditivos enzimáticos não provocou alterações no conteúdo de MS dos tratamentos avaliados. 
Tabela 8. Características bromatológicas e fermentativas das silagens de capim Tanzânia com e sem adição de enzimas fibrolíticas e composição bromatológica do concentrado

\begin{tabular}{|c|c|c|c|c|c|c|c|c|c|c|c|}
\hline \multirow{2}{*}{ Variáveis } & \multirow{2}{*}{$\operatorname{Con}^{1}$} & \multicolumn{5}{|c|}{ Tratamentos $^{2}$} & \multirow{2}{*}{$\begin{array}{l}\mathrm{CV} \\
(\%)\end{array}$} & \multicolumn{4}{|c|}{ Contrastes $(\mathrm{P}<)^{3}$} \\
\hline & & A & B & $\mathrm{C}$ & $\mathrm{D}$ & $\mathrm{E}$ & & 1 & 2 & 3 & 4 \\
\hline$\overline{\mathrm{MS}, \%}$ & 85,4 & 24,2 & 20,6 & 23,9 & 21,5 & 21,7 & 5 & $* *$ & 0,65 & 0,13 & 0,77 \\
\hline MO, \% & 94,5 & 87,6 & 90,2 & 87,4 & 89,1 & 90,2 & 1 & $* *$ & 0,66 & 0,32 & $\dagger$ \\
\hline MM, \% MS & 5,55 & 12,4 & 9,8 & 12,6 & 10,8 & 9,8 & 8 & $* *$ & 0,66 & 0,32 & $\dagger$ \\
\hline $\mathrm{PB}, \% \mathrm{MS}$ & 22,9 & 5,92 & 2,71 & 6,07 & 2,54 & 2,77 & 14 & $* *$ & 0,69 & 0,87 & 0,53 \\
\hline $\mathrm{EE}, \% \mathrm{MS}$ & 4,47 & 1,91 & 2,20 & 1,81 & 2,10 & 2,21 & 14 & $*$ & 0,58 & 0,76 & 0,55 \\
\hline FDN, \% MS & 31,1 & 71,5 & 76,5 & 70,0 & 73,7 & 77,1 & 3 & $* *$ & 0,37 & 0,44 & $*$ \\
\hline FDA, \% MS & 8,5 & 45,2 & 49,0 & 44,1 & 46,0 & 49,6 & 4 & $* *$ & 0,34 & 0,23 & $* *$ \\
\hline CEL, \% MS & 5,4 & 37,9 & 41,8 & 35,4 & 38,9 & 41,9 & 4 & $* *$ & $*$ & 0,13 & $* *$ \\
\hline HEMI, \% MS & 22,6 & 26,2 & 27,5 & 26,0 & 27,8 & 27,5 & 7 & $\dagger$ & 0,82 & 0,88 & 0,85 \\
\hline CHO, \% MS & 2,81 & 0,73 & 0,48 & 1,10 & 0,47 & 0,52 & 30 & $* *$ & $* *$ & 0,86 & 0,72 \\
\hline LIG, \% MS & 2,89 & 5,39 & 5,14 & 5,60 & 4,70 & 5,29 & 25 & 0,40 & 0,80 & 0,85 & 0,48 \\
\hline $\mathrm{CNF}^{4}, \% \mathrm{MS}$ & 36,0 & 8,3 & 8,8 & 9,4 & 10,8 & 8,1 & 28 & 0,74 & 0,49 & 0,62 & 0,11 \\
\hline $\mathrm{N}-\mathrm{NH}^{3}(\% \mathrm{NT})$ & - & 8,05 & 20,35 & 5,15 & 19,0 & 19,4 & 37 & $* *$ & 0,13 & 0,48 & 0,85 \\
\hline $\mathrm{pH}$ & - & 5,17 & 5,26 & 5,05 & 5,14 & 5,28 & 6 & 0,33 & 0,55 & 0,73 & 0,43 \\
\hline
\end{tabular}

${ }^{1}$ Análise bromatológica do concentrado.

${ }^{2}$ Tratamentos = A - silagem emurchecida; B - silagem sem emurchecimento; C - silagem emurchecida com enzimas; D - silagem sem emurchecimento com enzimas; $\mathrm{E}$ - silagem sem emurchecimento com enzimas aplicadas após abertura do silo.

${ }^{3}$ Contrastes $=1$. efeito emurchecimento $(A+C$ vs. $B+D+E)$, 2. efeito enzimas - emurchecimento (A vs. C), 3. efeito enzimas - sem emurchecimento (B vs D+E), 4. efeito do momento de aplicação da enzima (D vs. E).

${ }^{4} \mathrm{CNF}=100-[\mathrm{FDN}+\mathrm{EE}+\mathrm{PB}+\mathrm{MM}]$

* Significativo a $5 \%$ de probabilidade, ** Significativo a $1 \%$ de probabilidade, † Significativo a $10 \%$ de probabilidade. 
Tabela 9. Composição bromatológica calculada para as rações experimentais com base na taxa de inclusão e composição dos ingredientes

\begin{tabular}{|c|c|c|c|c|c|c|c|c|c|c|}
\hline \multirow{2}{*}{ Variáveis } & \multicolumn{5}{|c|}{ Rações $^{1}$} & \multirow{2}{*}{$\mathrm{CV}$} & \multicolumn{4}{|c|}{ Contrastes $(\mathrm{P}<)^{3}$} \\
\hline & A & $\mathrm{B}$ & $\mathrm{C}$ & $\mathrm{D}$ & $\mathrm{E}$ & & 1 & 2 & 3 & 4 \\
\hline IS, \% & 54,99 & 53,18 & 54,84 & 53,64 & 53,74 & 1 & $* *$ & 0,65 & 0,13 & 0,76 \\
\hline MO, \% & 91,05 & 92,33 & 90,93 & 91,82 & 92,33 & 1 & $* *$ & 0,66 & 0,31 & $\dagger$ \\
\hline MM, \% MS & 8,95 & 7,68 & 9,07 & 8,17 & 7,67 & 5 & $* *$ & 0,66 & 0,31 & $\dagger$ \\
\hline $\mathrm{PB}, \% \mathrm{MS}$ & 14,45 & 12,86 & 14,53 & 12,77 & 12,89 & 2 & $* *$ & 0,69 & 0,87 & 0,54 \\
\hline $\mathrm{EE}, \% \mathrm{MS}$ & 3,20 & 3,34 & 3,15 & 3,29 & 3,35 & 4 & $*$ & 0,60 & 0,74 & 0,54 \\
\hline FDN, \% MS & 51,17 & 53,66 & 50,46 & 52,30 & 53,96 & 2 & $* *$ & 0,37 & 0,43 & * \\
\hline FDA, \% MS & 26,74 & 28,62 & 26,17 & 27,12 & 28,90 & 3 & $* *$ & 0,34 & 0,23 & $* *$ \\
\hline CEL, \% MS & 21,58 & 23,51 & 20,35 & 22,08 & 23,55 & 4 & $* *$ & $*$ & 0,13 & $* *$ \\
\hline HEMI, \% MS & 24,42 & 25,03 & 24,28 & 25,17 & 25,06 & 4 & $\dagger$ & 0,82 & 0,87 & 0,85 \\
\hline LIG, \% MS & 4,13 & 4,01 & 4,24 & 3,79 & 4,08 & 16 & 0,40 & 0,81 & 0,85 & 0,48 \\
\hline $\mathrm{CNF}^{2}, \% \mathrm{MS}$ & 22,23 & 22,45 & 22,79 & 23,46 & 22,14 & 6 & 0,75 & 0,50 & 0,63 & 0,13 \\
\hline
\end{tabular}

Proporção dos ingredientes: 49,69\% de silagem de capim Tanzânia, 47,18\% de milheto, 1,67\% de uréia e $1,46 \%$ de premix mineral vitamínico.

${ }^{1}$ Rações experimentais $=\mathrm{A}-$ concentrado + silagem emurchecida; $\mathrm{B}$ - concentrado + silagem sem emurchecimento; $\mathrm{C}$ - concentrado + silagem emurchecida com enzimas; D - concentrado

+ silagem sem emurchecimento com enzimas; E - concentrado + silagem sem emurchecimento com enzimas aplicadas após abertura do silo.

${ }^{2} \mathrm{CNF}=100-[\mathrm{FDN}+\mathrm{EE}+\mathrm{PB}+\mathrm{MM}]$.

${ }^{3}$ Contrastes $=1$. efeito emurchecimento $(\mathrm{A}+\mathrm{C}$ vs. $\mathrm{B}+\mathrm{D}+\mathrm{E})$; 2. efeito enzimas - emurchecimento (A vs. C), 3. efeito enzimas - sem emurchecimento (B vs. D+E), 4. efeito do momento de aplicação da enzima (D vs E).

Efeitos: não-significativo, ns - significativo, † $\mathrm{P}<0,10,{ }^{*} \mathrm{P}<0,05,{ }^{* *} \mathrm{P}<0,01$.

Os maiores teores de cinzas foram observados para as silagens emurchecidas, em que ocorreu o efeito $(\mathrm{P}<0,01)$ do conteúdo de MS sobre a fração mineral das silagens, provavelmente devido à possível contaminação do solo na captação de forragem (Tabela 8). O processo de respiração mais intenso poderia também resultar em maiores perdas de carboidratos solúveis, aumentando a concentração da fração mineral; contudo, essa justificativa não seria plausível, uma vez que não houve aumento de FDN em silagens com maior teor de MS.

Para a fração FDN, o teste $F$ indicou diferença significativa $(P<0,01)$ entre tratamentos emurchecidos e não-emurchecidos (Tabela 8). Verificou-se que os valores 
médios para a variável FDN foram de 70,75 e 75,77\% para silagens emurchecidas e nãoemurchecidas, respectivamente. Em adição, nas silagens com maior teor de MS não só houve efeito significativo $(\mathrm{P}<0,01)$ na redução do conteúdo de FDN, FDA e celulose, como também redução $(\mathrm{P}<0,10)$ do conteúdo de hemicelulose, sugerindo que o emurchecimento provavelmente atuaria estimulando a ativação de enzimas fibrolíticas presentes na forragem. Segundo Igarasi (2002), a ação da celulase da própria planta seria o fator responsável pela redução da fração de celulose no capim Tanzânia emurchecido.

Castro (2002), avaliando o uso de inoculante bacteriano enzimático na produção de silagem de Tifton 85 emurchecida, verificou decréscimo $(P<0,05)$ do teor de FDN com o aumento da concentração de matéria seca das silagens, no primeiro instante até 16 dias após a ensilagem. No entanto, esse parâmetro sofreu acréscimo $(\mathrm{P}<0,05)$ com o incremento do conteúdo de matéria seca aos 8 e 32 dias após o fechamento dos silos. Aos 90 e 180 dias de estocagem, não houve diferença significativa $(\mathrm{P}>0,10)$ entre os tratamentos.

Constatou-se no presente experimento que houve diferença significativa $(\mathrm{P}<0,05)$ dos componentes da parede celular, entre as formas de aplicação das enzimas fibrolíticas nas silagens não-emurchecidas (D vs. E) (Tabela 8). No tratamento em que as enzimas fibrolíticas foram aplicadas na ensilagem, houve redução de 3,35 unidades percentuais para a FDN, 3,58 para a FDA e 2,95 para a celulose, em relação ao tratamento cuja aplicação da enzima ocorreu após a abertura do silo. Esse fato pode indicar que a aplicação das enzimas fibrolíticas no início da ensilagem tenha proporcionado maior contato da enzima com a forragem que quando aplicada 30 minutos antes do fornecimento ao animal.

De acordo com Woolford (1984), a preparação enzimática celulolítica seria mais efetiva em silagens provenientes de cortes diretos que naquelas que sofreram processo de emurchecimento, alegando que a umidade influenciaria a atividade enzimática. No entanto, Feng et al. (1992) constataram que a aplicação de enzimas fibrolíticas foi mais eficaz em gramíneas com teores mais elevados de MS. Muck \& Kung Junior (1997) afirmaram que o melhor teor de umidade para ensilagem de alfafa e gramínea, com aditivos enzimáticos, estaria entre 60 e 70\%. Além disso, segundo esses 
autores, os produtos enzimáticos não seriam muito eficientes em substratos muito úmidos. Conforme essa afirmativa, não seria de se esperar que ocorresse efeito de redução da fração fibrosa em decorrência da aplicação das enzimas fibrolíticas, uma vez que, no presente experimento, as silagens apresentaram cerca de $80 \%$ de umidade. No entanto, a aplicação das enzimas fibrolíticas na ensilagem proporcionou efeitos significativos na redução da fração fibrosa, conforme apresentados na Tabela 8.

A forma de aplicação de enzimas pode ser considerada como ponto crítico para obtenção de bons resultados na silagem e na nutrição de ruminantes. Neste experimento, é importante destacar que a aplicação das enzimas fibrolíticas sempre foi realizada sobre a forragem, ou silagem, que foi posteriormente misturada ao concentrado.

Recomenda-se que a pulverização da solução enzimática seja realizada sobre o concentrado ou sobre a porção mais seca da dieta para que a solução enzimática seja mais efetiva. Yang et al. (2000) observaram que a pulverização de enzimas fibrolíticas sobre a ração de mistura total não foi efetiva; Beauchemin et al. (1995) também não verificaram efetividade aplicando-as sobre as silagens. Estes pesquisadores sugerem que, quando os aditivos enzimáticos são aplicados diretamente sobre as silagens ou sobre a ração de mistura total antes do fornecimento ao animal, eles iniciam sua ação e passam rapidamente pelo rúmen antes de conseguirem agir efetivamente sobre o alimento. Vários estudos têm mostrado que a pulverização de enzimas fibrolíticas na porção da dieta representada pela silagem, antes de compor a ração de mistura total, resultou em maior produção de leite (Schingoethe et al., 1999; Kung et al., 2000a, 2000b; Zheng et al., 2000).

Nsereko et al. (2000) constataram que substâncias inibitórias não correlacionadas aos ácidos orgânicos estão presentes em silagens e podem causar redução da atividade enzimática de xilanase, sem afetar, contudo, a celulase. Essa descoberta pode explicar uma série de resultados obtidos anteriormente sobre o efeito da adição de enzimas fibrolíticas em silagens de gramíneas. No presente experimento, pode-se inferir que a atividade de celulase manteve-se relativamente mais estável que a da xilanase, visto que o desaparecimento da fração celulose mostrou-se quantitativamente superior. 
Para o teor de $\mathrm{PB}$, detectou-se efeito significativo $(\mathrm{P}<0,01)$ com o aumento do teor de MS, sendo os valores médios observados para as silagens emurchecidas e nãoemurchecidas foram de 6 e 2,67\%, respectivamente (Tabela 8). Possivelmente, o baixo valor de PB observado nas silagens mais úmidas pode ser devido à forma em que foi realizada a amostragem da silagem, pois, durante o período de coleta, as amostras eram retiradas do congelador diariamente, ficando expostas à temperatura ambiente e sendo intensamente manuseadas. Esse procedimento pode ter favorecido a degradação protéica das silagens com menor teor de MS e essa intensa proteólise e deaminação, proporcionando perdas na fração nitrogenada, que podem ser confirmadas verificando os elevados teores de nitrogênio amoniacal (Tabela 8).

Avaliando-se isoladamente apenas a composição bromatológica das silagens, o uso de enzimas fibrolíticas mostrou-se mais eficiente na redução da fração fibrosa da forragem quando aplicada na ensilagem. Os resultados obtidos com a técnica de emurchecimento não potencializaram o efeito de degradação da fibra com a adição de enzimas, porém evidenciaram o potencial para a obtenção de silagens com menores perdas, no processo fermentativo, de carboidratos solúveis e nitrogênio amoniacal.

\subsubsection{Cinética, ingestão e comportamento ingestivo dos animais}

\subsubsection{Taxa de passagem e tempo de retenção}

A taxa média de passagem ruminal calculada para sólidos, de 2,23\% $\mathrm{h}^{-1}$ $(\mathrm{P}>0,10)$, e líquidos, de 4,83\% $\mathrm{h}^{-1}(\mathrm{P}>0,10)$, não apresentou significância pelo teste $\mathrm{F}$ (Tabela 10). Portanto, não houve diferença entre os tratamentos avaliados no que se refere à taxa de passagem de líquidos e sólidos.

Segundo Nelson \& Satter (1992), as taxas de passagem e de digestão seriam mais elevadas para as silagens do que para fenos de alfafa. Em trabalho mais recente, constatou-se o mesmo efeito comparando dietas com maior ou menor conteúdo de silagem. Dietas com maior proporção de silagem apresentaram maiores taxas de passagem tanto para líquidos quanto para sólidos (Yang et al., 2002a). Entretanto, os 
valores obtidos por Ribeiro et al. (2001) para fenos de capim Tifton 85 foram mais elevados do que os resultados com silagem de capim Tanzânia no presente experimento. Esses autores estimaram a taxa de passagem média de partículas 2,78; 3,49; 3,16 e $3,36 \% \mathrm{~h}^{-1}$ em animais que consumiram rações contendo feno de capim Tifton 85 colhido aos 28, 35, 42 e 56 dias de crescimento vegetativo, respectivamente, as quais não diferiram estatisticamente, encontrando-se como média geral $3,36 \% \mathrm{~h}^{-1}$.

Tabela 10. Taxas de passagem de sólidos da silagem e de líquidos em bovinos que receberam rações contendo silagem de capim Tanzânia com e sem adição de enzimas fibrolíticas

\begin{tabular}{lcccccccccc}
\hline & \multicolumn{4}{c}{ Tratamentos $^{1}$} & & \multicolumn{4}{c}{ CV } & \multicolumn{4}{c}{ Contrastes $(\mathrm{P}<)^{2}$} \\
Variáveis & A & $\mathrm{B}$ & $\mathrm{C}$ & $\mathrm{D}$ & $\mathrm{E}$ & $(\%)$ & 1 & 2 & 3 & 4 \\
\hline
\end{tabular}

Taxa de passagem

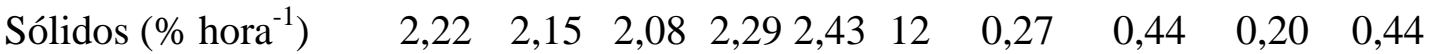

$\begin{array}{lllllllllll}\text { Líquidos }\left(\% \text { hora }^{-1}\right) & 5,09 & 4,78 & 4,67 & 4,79 & 4,86 & 12 & 0,77 & 0,26 & 0,89 & 0,84\end{array}$

${ }^{1}$ Tratamentos = A - silagem emurchecida; B - silagem sem emurchecimento; C - silagem emurchecida com enzimas; D - silagem sem emurchecimento com enzimas; E - silagem sem emurchecimento com enzimas aplicadas após abertura do silo.

${ }^{2}$ Contrastes $=1$. efeito emurchecimento $(A+C$ vs. $B+D+E)$, 2. efeito enzimas - emurchecimento (A vs C), 3. efeito enzimas - sem emurchecimento (B vs. D+E), 4. efeito do momento de aplicação da enzima ( $D$ vs $E$ ).

Coelho (2002), avaliando os efeitos da concentração de matéria seca e do uso de inoculante bacteriano-enzimático em silagens de capim Tifton 85, não verificou efeito significativo entre os tratamentos. Os valores médios para taxa de passagem de sólidos e líquidos obtidos foram, respectivamente, de 2,6 e 4,4\% $\mathrm{h}^{-1}$, resultados estes, semelhantes aos obtidos para as silagens de capim Tanzânia neste experimento. Os dados também são similares aos obtidos por Phuntsok et al. (1998) e Yang et al. (2002a), que não verificaram alteração na taxa de passagem do conteúdo líquido em função da diferença dos teores de MS.

O tempo de retenção (TR), ou seja, o tempo em que o alimento permaneceu no rúmen, foi calculado através da fórmula $\mathrm{TR}=1 \mathrm{k}^{-1}$, sendo $\mathrm{k}$ a taxa de passagem de 
sólidos. Para suplementos protéicos, os valores do TR apresentam uma variação de 10 a 50 horas, enquanto para substratos mais fibrosos a amplitude gira em torno de 20 a 60 horas (Orskov, 2002). Similarmente ao ocorrido com a taxa de passagem, neste experimento, não houve efeito $(\mathrm{P}>0,10)$ dos tratamentos aplicados sobre o tempo de retenção, obtendo-se o valor médio de 45 horas.

A ingestão de MS é influenciada pela taxa de digestão e taxa de passagem do alimento no rúmen (Henriques et al., 2001; Colucci et al., 1990). Pelos resultados apresentados na Tabela 11, constatou-se que não houve efeito significativo $(P>0,10)$ sobre a ingestão de MS dos tratamentos com, ou sem, enzimas fibrolíticas no presente experimento. Portanto, pode-se inferir que o consumo de matéria seca, neste experimento, esteve relacionado com a estimativa da taxa de passagem, pois esta também não foi alterada em função dos tratamentos aplicados.

\subsubsection{Comportamento ingestivo do animal}

Na seqüência cronológica das atividades diárias, após a oferta matutina de alimentos, representada por $70 \%$ da ração, notou-se um período de alimentação em torno de três horas sem interrupção para todos os animais, seguido por um período de cerca de 30 minutos, em que os bois permaneceram em ócio. A partir deste horário, longos períodos de ruminação passaram a ser alternados com períodos de ócio, em que breves períodos de ingestão de alimentos e água também puderam ser constatados. Após o oferecimento da segunda refeição, às 17 horas, a freqüência da alimentação noturna se fez constante por aproximadamente uma hora; e em seguida, a sucessão de eventos observados durante o período diurno se repetiu.

O tempo médio de ingestão dos alimentos observado, durante o período de análise do comportamento ingestivo dos animais, não se mostrou diferente entre tratamentos $(\mathrm{P}>0,10)$, podendo-se considerar que os animais, em média, utilizaram 247 minutos para realizar suas refeições, conforme observado na Tabela 11. A análise pelo teste F não acusou diferença significativa $(\mathrm{P}>0,10)$ entre os tratamentos para os tempos

médios de ócio (748) e ingestão de água (17), expressos em minutos. Contudo, para 
ingestão de água, o coeficiente de variação se mostrou elevado (70\%), devido a uma ampla variação individual no consumo de água.

Valores similares foram encontrados por Coelho (2002), ao observar bovinos da raça Nelore que receberam silagem de capim Tifton 85 (representando 80\% da dieta), não verificando diferença do efeito do conteúdo de matéria seca e do uso de inoculante bacteriano-enzimático para os tempos médios de ruminação, ócio, mastigação e ingestão de água. O autor constatou, também, que os tempos despendidos no exercício de cada atividade diária, para todos os tratamentos, foram fracionados ao longo das 24 horas em, 517 minutos dispensados para ruminação, 567 minutos em ócio, 841 minutos para mastigação e 31 minutos para ingestão de água. No experimento realizado por Coelho (2002) verificou-se também um elevado coeficiente de variação para a ingestão de água (53\%).

Em vacas primíparas e multíparas que receberam dietas contendo 50\% de concentrado, observa-se que existe diferença do comportamento ingestivo entre as categorias. Maekawa et al. (2002) verificaram que vacas multíparas passavam 560 minutos ruminando, 619 minutos em ócio e 821 minutos mastigando e que as vacas primíparas passavam 508 minutos ruminando, 720 minutos em ócio e 720 minutos mastigando. Observaram, ainda, que a taxa de salivação foi maior em vacas multíparas do que nas primíparas, causada provavelmente por uma resposta involuntária de redução do tempo em ócio e devido à necessidade de tamponamento ruminal.

Não se detectou efeito $(\mathrm{P}>0,10)$, pelo teste $\mathrm{F}$, entre os tratamentos para a taxa de ingestão de MS no consumo médio de matéria seca da dieta; a média de taxa de

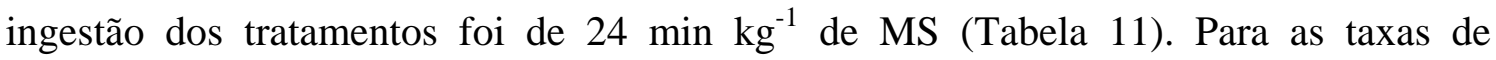
ruminação e mastigação, verificou-se efeito significativo $(P<0,05)$ entre os grupos de tratamentos com e sem o emurchecimento. O tempo de ruminação e mastigação total em min $\mathrm{kg}^{-1}$ de MS diminuiu nas dietas com silagens emurchecidas, apesar de o tempo médio de ingestão de MS não ter apresentado diferença entre os tratamentos. $\mathrm{O}$ fato de o consumo de MS destas dietas ter sido maior, conforme pode ser observado na Tabela 12, pode estar associado ao menor tempo gasto ruminando e mastigando. 
Tabela 11. Variáveis do comportamento ingestivo em bovinos que receberam rações contendo silagem de capim Tanzânia com e sem adição de enzimas fibrolíticas

\begin{tabular}{|c|c|c|c|c|c|c|c|c|c|c|c|}
\hline \multirow{2}{*}{ Variáveis } & \multicolumn{5}{|c|}{ Tratamentos $^{1}$} & \multirow{2}{*}{$\begin{array}{l}\text { CV } \\
(\%)\end{array}$} & \multirow{2}{*}{ Médias } & \multicolumn{4}{|c|}{ Contrastes $(\mathrm{P}<)^{2}$} \\
\hline & A & $\mathrm{B}$ & $\mathrm{C}$ & $\mathrm{D}$ & $\mathrm{E}$ & & & 1 & 2 & 3 & 4 \\
\hline \multicolumn{12}{|l|}{ Ingestão de MS } \\
\hline $\min \operatorname{dia}^{-1}$ & $247^{\mathrm{a}}$ & $262^{\mathrm{a}}$ & $241^{\mathrm{a}}$ & $247^{\mathrm{a}}$ & $238^{a}$ & 13 & 247 & 0,72 & 0,78 & 0,27 & 0,64 \\
\hline $\min \mathrm{kg}^{-1} \mathrm{MSI}^{3}$ & $22^{\mathrm{a}}$ & $27^{\mathrm{a}}$ & $24^{\mathrm{a}}$ & $24^{\mathrm{a}}$ & $25^{a}$ & 18 & 24 & 0,27 & 0,58 & 0,32 & 0,77 \\
\hline $\min \mathrm{kg}^{-1} \mathrm{FDN}^{4}$ & $44^{\mathrm{a}}$ & $50^{\mathrm{a}}$ & $46^{\mathrm{a}}$ & $46^{\mathrm{a}}$ & $47^{\mathrm{a}}$ & 19 & 47 & 0,56 & 0,74 & 0,45 & 0,87 \\
\hline \multicolumn{12}{|l|}{ Ruminação } \\
\hline $\min \operatorname{dia}^{-1}$ & $427^{\mathrm{ab}}$ & $443^{a}$ & $391^{b}$ & $430^{a b}$ & $439^{a}$ & 5 & 426 & $* *$ & $*$ & 0,49 & 0,52 \\
\hline $\min \mathrm{kg}^{-1} \mathrm{MSI}$ & $40^{\mathrm{ab}}$ & $46^{\mathrm{a}}$ & $39^{\mathrm{b}}$ & $43^{\mathrm{ab}}$ & $46^{\mathrm{a}}$ & 8 & 43 & $* *$ & 0,74 & 0,46 & 0,12 \\
\hline $\min \mathrm{kg}^{-1} \mathrm{FDN}$ & $79^{\mathrm{a}}$ & $85^{\mathrm{a}}$ & $76^{\mathrm{a}}$ & $82^{a}$ & $87^{a}$ & 10 & 82 & $*$ & 0,58 & 0,82 & 0,36 \\
\hline \multicolumn{12}{|l|}{ Mastigação } \\
\hline $\min \mathrm{dia}^{-1}$ & $674^{\mathrm{a}}$ & $705^{a}$ & $633^{a}$ & $677^{a}$ & $676^{\mathrm{a}}$ & 5 & 673 & $*$ & 0,10 & 0,19 & 0,98 \\
\hline $\min \mathrm{kg}^{-1} \mathrm{MSI}$ & $62^{\mathrm{a}}$ & $73^{a}$ & $63^{a}$ & $66^{\mathrm{a}}$ & $71^{\mathrm{a}}$ & 10 & 67 & $* *$ & 0,85 & 0,32 & 0,33 \\
\hline min $\mathrm{kg}^{-1} \mathrm{FDN}$ & $123^{\mathrm{a}}$ & $136^{\mathrm{a}}$ & $122^{\mathrm{a}}$ & $128^{\mathrm{a}}$ & $134^{\mathrm{a}}$ & 12 & 128 & 0,16 & 0,93 & 0,58 & 0,57 \\
\hline \multicolumn{12}{|l|}{ Ócio } \\
\hline $\min \operatorname{dia}^{-1}$ & $746^{\mathrm{a}}$ & $715^{\mathrm{a}}$ & $787^{\mathrm{a}}$ & $737^{a}$ & $753^{\mathrm{a}}$ & 6 & 748 & $\dagger$ & 0,15 & 0,22 & 0,57 \\
\hline \multicolumn{12}{|c|}{ Ingestão de água } \\
\hline $\min \operatorname{dia}^{-1}$ & $20^{\mathrm{a}}$ & $20^{\mathrm{a}}$ & $20^{a}$ & $13^{\mathrm{a}}$ & $11^{\mathrm{a}}$ & 70 & 17 & 0,28 & 0,98 & 0,24 & 0,79 \\
\hline
\end{tabular}


Segundo Grant (1997), o tempo de mastigação diminui com a redução do teor de FDN na dieta ou do tamanho de partícula, embora, em alguns casos, a ruminação por unidade de consumo de FDN na forragem aumente quando se reduz a concentração de FDN da dieta. Contudo, apesar de as rações com silagens emurchecidas e não emurchecidas apresentarem teores significativamente diferentes de FDN na dieta (Tabela 9), este fator, provavelmente, não influenciou o tempo gasto para ruminação e mastigação.

$\mathrm{Na}$ análise da ingestão de FDN na dieta em $\mathrm{kg} \mathrm{FDN} \mathrm{dia}^{-1}$, não foi verificada diferença significativa $(\mathrm{P}>0,10)$ entre os tratamentos impostos, havendo um consumo médio de 5,35 kg de FDN, equivalente a 1,18\% do peso corpóreo (Tabela 12). Portanto, este valor encontra-se próximo ao consumo ideal diário de FDN, que é de $11 \mathrm{~g} \mathrm{~kg}^{-1}$ do peso corpóreo (Glenn \& Waldo, 1994), para que não haja limitação do consumo de MS.

Não houve diferença significativa $(\mathrm{P}>0,10)$ entre os tratamentos para a taxa de ingestão de FDN e a taxa de mastigação de FDN, com base no consumo médio de matéria seca da dieta (Tabela 11). Resultado semelhante foi obtido por Mendes Neto et al. (2001), avaliando o efeito da substituição do feno de Tifton 85 por polpa de citrus; não observaram diferença entre o tempo despendido com alimentação e com mastigação total em min $\mathrm{kg}^{-1}$ para dietas com feno ou polpa de cítrus.

$\mathrm{O}$ efeito significativo $(\mathrm{P}<0,05)$ do uso de enzimas fibrolíticas sobre $\mathrm{o}$ comportamento ingestivo foi observado somente em dietas com silagens de capim Tanzânia emurchecido, havendo redução do tempo de ruminação de $427 \mathrm{~min}_{\text {dia }}{ }^{-1}$ para

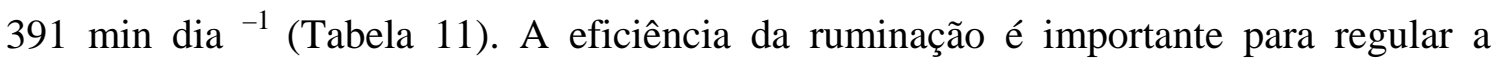
utilização de alimentos de menor digestibilidade, pois o animal pode ruminar maior quantidade de alimentos, proporcionando maior consumo. Em virtude do maior teor de matéria seca, observa-se que a eficiência de ruminação é melhor, visto que os animais gastam menor tempo de ruminação e de alimentação (Beauchemin \& Buchanan-Smith, 1989; Miranda et al., 1999). No entanto, essa eficiência não foi verificada no presente estudo, uma vez que não houve alteração no consumo da ração. Apesar disso, a adição de enzimas no alimento poderia ter um efeito de pré-digestão, reduzindo o tempo de mastigação por unidade de FDN, conforme Bowman et al. (2003). 
O levantamento dos dados sobre o comportamento, proposto neste trabalho, sugere que os diferentes teores de matéria seca em silagens de capim Tanzânia, associados ao uso de enzimas fibrolíticas na ensilagem ou pouco antes do fornecimento ao animal, não causaram grandes alterações no comportamento ingestivo de novilhos Nelore.

\subsubsection{Ingestão de Matéria Seca}

A análise do consumo de MS revelou não haver diferença $(\mathrm{P}>0,10)$ para os contrastes A vs. C, B vs. D+E e D vs. E, indicando ausência do efeito da adição de enzimas fibrolíticas nas rações (Tabela 12). Esse resultado pode estar associado à forma de avaliação, uma vez que esta foi realizada utilizando-se cinco animais com cânulas duodenais e ruminais confinados em gaiolas metabólicas. Aconselha-se para esse tipo de análise a realização de experimentos voltados exclusivamente para avaliação de desempenho produtivo dos animais, pois respostas positivas têm sido obtidas dessa forma.

Michal et al. (1996) relataram que o efeito observado da aplicação de enzimas fibrolíticas para novilhos em crescimento proporcionou aumentos de consumo e ganho de peso. Segundo os autores, a aplicação das enzimas durante o fornecimento de feno de alfafa proporcionou acréscimo de $8,5 \%$ no consumo $(\mathrm{P}<0,06)$ e tendência de aumento de ganho de peso $(\mathrm{P}<0,14)$. Em outro experimento, conduzido por Pritchard et al. (1996), com gado de corte, utilizando rações compostas por 52,5 \% de silagem de alfafa, 17,5\% de feno de gramínea e 30\% de cevada triturada, a adição de enzimas fibrolíticas aumentou o consumo da matéria seca linearmente $(\mathrm{P}<0,10)$ com o acréscimo da dose aplicada da mistura celulase:xilanase, porém o mesmo não foi observado para a ração que recebeu solução enzimática contendo celulase exclusivamente.

Nos experimentos com vacas leiteiras, a discussão relacionada à ingestão de 
Tabela 12. Quadrados mínimos para o consumo de matéria seca e de FDN em bovinos tratados com rações contendo silagem de capim Tanzânia com e sem adição de enzimas fibrolíticas

\begin{tabular}{|c|c|c|c|c|c|c|c|c|c|c|}
\hline \multirow{2}{*}{ Variáveis } & \multicolumn{5}{|c|}{ Tratamentos $^{1}$} & \multirow{2}{*}{$\begin{array}{l}\text { CV } \\
\text { (\%) }\end{array}$} & \multicolumn{4}{|c|}{ Contraste $(\mathrm{P}<)^{2}$} \\
\hline & $\mathrm{A}$ & B & $\mathrm{C}$ & $\mathrm{D}$ & $\mathrm{E}$ & & 1 & 2 & 3 & 4 \\
\hline \multicolumn{11}{|l|}{ Ingestão de MS } \\
\hline kg MS dia ${ }^{-1}$ & $11,06^{\mathrm{a}}$ & $9,82^{\mathrm{a}}$ & $10,44^{\mathrm{a}}$ & $10,22^{a}$ & $9,74^{\mathrm{a}}$ & 9 & * & 0,29 & 0,75 & 0,41 \\
\hline kg MS 100 kg peso-1 & $2,20^{\mathrm{a}}$ & $1,94^{\mathrm{a}}$ & $2,05^{\mathrm{a}}$ & $2,03^{\mathrm{a}}$ & $1,94^{\mathrm{a}}$ & 8 & * & 0,15 & 0,52 & 0,52 \\
\hline \multicolumn{11}{|l|}{ Ingestão de FDN } \\
\hline FDN dieta (\%) & $47,98^{b}$ & $50,39^{a}$ & $48,01^{b}$ & $49,60^{a b}$ & $51,01^{a}$ & 3 & $* *$ & 0,97 & 0,90 & 0,11 \\
\hline kg FDN dia ${ }^{-1}$ & $5,56^{\mathrm{a}}$ & $5,24^{\mathrm{a}}$ & $5,38^{\mathrm{a}}$ & $5,35^{\mathrm{a}}$ & $5,20^{\mathrm{a}}$ & 9 & 0,31 & 0,54 & 0,86 & 0,63 \\
\hline kg FDN $100 \mathrm{~kg}$ peso $^{-1}$ & $1,11^{\mathrm{a}}$ & $1,03^{\mathrm{a}}$ & $1,05^{\mathrm{a}}$ & $1,06^{\mathrm{a}}$ & $1,05^{\mathrm{a}}$ & 8 & 0,35 & 0,31 & 0,60 & 0,86 \\
\hline
\end{tabular}

${ }^{1}$ Tratamentos = A - silagem emurchecida; $\mathrm{B}$ - silagem sem emurchecimento; C - silagem emurchecida com enzimas; D - silagem sem emurchecimento com enzimas; $\mathrm{E}$ - silagem sem emurchecimento com enzimas aplicadas após abertura do silo.

${ }^{2}$ Contrastes $=1$. efeito emurchecimento $(A+C$ vs. $B+D+E)$, 2. efeito enzimas - emurchecimento (A vs. $\left.C\right)$, 3. efeito enzimas - sem emurchecimento (B vs. D+E), 4. efeito do momento de aplicação da enzima (D vs. E).

Médias, na linha, seguidas de letras diferentes, para cada tratamento, são diferentes $(\mathrm{P}<0,05)$ pelo teste Tukey.

* Significativo a $5 \%$ de probabilidade , ** Significativo a $1 \%$ de probabilidade. 
MS é bem mais ampla. Avaliando o efeito de enzimas fibrolíticas, Yang et al. (1998) não observaram diferença significativa de consumo em dietas fornecidas para vacas leiteiras contendo $25 \%$ de silagem de milho, $15 \%$ de feno de alfafa e $60 \%$ de concentrado. Em outro trabalho, Schingoethe et al. (1999) verificaram que o consumo de MS foi semelhante $(\mathrm{P}>0,10)$ entre dietas-controle e com diferentes doses de enzimas fibrolíticas aplicadas no momento do fornecimento da silagem aos animais. Os mesmos resultados com suplementos enzimáticos para vacas leiteiras foram verificados por Rode et al. (1999). De acordo com esses autores, a ausência do efeito da adição de misturas enzimáticas sobre o consumo de matéria seca é observada em outros experimentos (Beauchemin et al., 1999; Yang et al., 1999), aplicando as enzimas fibrolíticas tanto em rações completas quanto na forragem ou concentrado isoladamente.

Apesar disso, alguns estudos constataram aumentos, ou mesmo, tendência de incrementos no consumo de vacas leiteiras que receberam diferentes suplementos enzimáticos com atividades de celulase e xilanase (Nussio et al.; 1997; Luchini et al., 1997). Esses experimentos indicam que algumas misturas enzimáticas podem aumentar o consumo de vacas leiteiras, porém esse efeito geralmente ocorre, ou é mais intenso, em vacas leiteiras no início de lactação, que apresentam balanço energético negativo e elevada produção de leite. Portanto, as aparentes contradições entre experimentos indicam que há diferentes modos de ação entre os diversos tipos de suplementos enzimáticos, podendo variar de acordo com a categoria animal e o peso corporal.

O consumo de matéria seca da dieta (Tabela 12), expresso em percentual do peso corpóreo, também não apresentou diferença significativa pelo teste $F(P>0,10)$ para os tratamentos que avaliaram o efeito de enzimas fibrolíticas. Assim, pode-se considerar que a média de consumo observada foi de 2,13 e 1,97\% do peso corpóreo para os tratamentos com silagem emurchecida e não-emurchecida, respectivamente.

Os efeitos significativos $(\mathrm{P}<0,05)$ para as variáveis associadas a ingestão de MS (kg MS dia ${ }^{-1}$ e $\mathrm{kg}$ MS $100 \mathrm{~kg}$ peso $^{-1}$ ) foram observados avaliando-se o efeito emurchecimento (Tabela 12). Como era de se esperar, o consumo de MS foi maior para silagens emurchecidas, resultado este, previamente discutido, relacionando uma possível 
melhora na eficiência de ruminação. Adicionalmente, esse resultado também pode estar relacionado aos reduzidos teores de $\mathrm{N}-\mathrm{NH}^{3}$ presentes nessas silagens (Tabela 8).

Portanto, os dados apresentados quanto ao consumo de MS (Tabela 12), associados ao uso de enzimas fibrolíticas na ensilagem ou pouco antes do fornecimento ao animal, não foram efetivos para aumentar o consumo, acarretando melhorias no desempenho dos novilhos Nelore. Embora tenha sido observado menor teor de FDN nas rações contendo silagens emurchecidas $(\mathrm{P}<0,01)$, a ingestão de FDN não foi alterada dentre os tratamentos impostos.

\subsubsection{Características da fermentação ruminal}

\subsubsection{1 pH, ácidos graxos voláteis e nitrogênio amoniacal}

Foi detectada diferença significativa para os valores de $\mathrm{pH}$ ruminal em função do tratamento $(\mathrm{P}<0,10)$ e horário de coleta $(\mathrm{P}<0,01)$, porém não foi verificada interação entre tratamento e horário de coleta $(\mathrm{P}>0,10)$, conforme pode ser observado na Tabela $13 . \mathrm{O}$ contraste entre os tratamentos com silagens emurchecidas e não-emurchecidas (A+C vs. $B+D+E$ ) foi realizado para verificar se houve efeito do conteúdo de matéria seca sobre o pH; através da análise estatística, pôde-se constatar que não houve diferença significativa $(P>0,10)$ entre os tratamentos. Também não houve efeito $(P>0,10)$ de contraste (B vs. $D+$

E e D vs. E) para os tratamentos que avaliaram o uso de enzimas fibrolíticas em silagens sem emurchecimento. No entanto, ao avaliar o uso de enzimas fibrolíticas em silagens com emurchecimento, verificou-se efeito significativo $(\mathrm{P}<0,05)$ desses tratamentos (A vs. C) sobre o pH ruminal.

Não há explicação aparente para a diferença entre os tratamentos A e C, visto que não houve diferença significativa na avaliação do nitrogênio amoniacal, conforme observado na Tabela 13. Nesse caso, poder-se-ia interpretar que o tamanho de partículas seria o fator responsável pela redução de $\mathrm{pH}$ nas silagens emurchecidas. Cerca de $50 \%$ da silagem apresentou tamanho de partículas inferior a $38 \mathrm{~mm}$. Além disso, segundo Mertens (1997), dietas com baixo conteúdo de fibra e com reduzido tamanho de partículas 
Tabela 13. Médias dos quadrados mínimos das variáveis ruminais observadas em bovinos tratados com rações contendo silagens de capim Tanzânia com e sem adição de enzimas fibrolíticas

\begin{tabular}{|c|c|c|c|c|c|c|c|c|c|c|c|c|}
\hline \multirow{2}{*}{ Variáveis } & \multicolumn{5}{|c|}{ Tratamentos $^{1}$} & \multicolumn{3}{|c|}{ Efeitos e interação $(\mathrm{P}<)$} & \multicolumn{4}{|c|}{ Contrastes $(\mathrm{P}<)^{2}$} \\
\hline & A & $\mathrm{B}$ & $\mathrm{C}$ & $\mathrm{D}$ & $\mathrm{E}$ & Trat & Horário & Trat*Horário & 1 & 2 & 3 & 4 \\
\hline \multicolumn{13}{|l|}{$\mathrm{AGV}(\mathrm{mM})$} \\
\hline $\mathrm{C} 2$ & $71,99^{\mathrm{a}}$ & $74,14^{\mathrm{a}}$ & $78,64^{\mathrm{a}}$ & $75,10^{\mathrm{a}}$ & $80,61^{\mathrm{a}}$ & 0,84 & $* *$ & 0,13 & 0,81 & 0,44 & 0,61 & 0,52 \\
\hline C3 & $17,85^{\mathrm{ab}}$ & $16,20^{\mathrm{b}}$ & $18,14^{\mathrm{ab}}$ & $16,87^{\mathrm{ab}}$ & $18,64^{\mathrm{a}}$ & 0,64 & $* *$ & 0,34 & 0,51 & 0,87 & 0,32 & 0,33 \\
\hline $\mathrm{C} 4$ & $11,85^{\mathrm{ab}}$ & $12,70^{\mathrm{ab}}$ & $11,71^{\mathrm{b}}$ & $12,21^{\mathrm{ab}}$ & $13,38^{\mathrm{a}}$ & 0,70 & $* *$ & $* *$ & 0,26 & 0,92 & 0,94 & 0,38 \\
\hline CI4 & $1,02^{\mathrm{ab}}$ & $1,03^{\mathrm{ab}}$ & $0,92^{\mathrm{b}}$ & $0,97^{\mathrm{b}}$ & $1,14^{\mathrm{a}}$ & 0,28 & $* *$ & $\dagger$ & 0,23 & 0,33 & 0,80 & 0,11 \\
\hline C5 & $0,86^{\mathrm{b}}$ & $1,00^{\mathrm{ab}}$ & $0,94^{\mathrm{b}}$ & $0,98^{\mathrm{ab}}$ & $1,12^{\mathrm{a}}$ & 0,51 & $* *$ & $* *$ & 0,17 & 0,56 & 0,69 & 0,38 \\
\hline CI5 & $1,39^{\mathrm{c}}$ & $1,86^{\mathrm{a}}$ & $1,46^{\mathrm{bc}}$ & $1,65^{\mathrm{ab}}$ & $1,70^{\mathrm{ab}}$ & 0,33 & $* *$ & $* *$ & $\dagger$ & 0,78 & 0,39 & 0,83 \\
\hline $\mathrm{C} 2 / \mathrm{C} 3$ & $4,07^{\mathrm{c}}$ & $4,56^{\mathrm{a}}$ & $4,31^{\mathrm{b}}$ & $4,49^{\mathrm{ab}}$ & $4,35^{\mathrm{b}}$ & $* *$ & $* *$ & $\dagger$ & $* *$ & * & 0,15 & 0,28 \\
\hline TOTAL & $104,96^{\mathrm{a}}$ & $106,95^{\mathrm{a}}$ & $111,82^{\mathrm{a}}$ & $107,80^{\mathrm{a}}$ & $116,61^{\mathrm{a}}$ & 0,84 & $* *$ & 0,13 & 0,78 & 0,55 & 0,60 & 0,45 \\
\hline $\mathrm{pH}$ & $6,48^{\mathrm{a}}$ & $6,36^{b}$ & $6,21^{c}$ & $6,44^{\mathrm{ab}}$ & $6,34^{b}$ & $\dagger$ & $* *$ & 0,88 & 0,56 & $* *$ & 0,69 & 0,22 \\
\hline N-amoniacal (mg dL $\left.{ }^{-1}\right)$ & $5,39^{\mathrm{ab}}$ & $5,12^{\mathrm{ab}}$ & $4,50^{\mathrm{b}}$ & $6,14^{\mathrm{ab}}$ & $6,60^{\mathrm{a}}$ & 0,42 & $* *$ & 0,60 & 0,19 & 0,48 & 0,22 & 0,72 \\
\hline
\end{tabular}

${ }^{1}$ Tratamentos: A - silagem emurchecida; B - silagem sem emurchecimento; C - silagem emurchecida com enzimas; D - silagem sem emurchecimento com enzimas; E - silagem sem emurchecimento com enzimas aplicadas após abertura do silo.

${ }^{2}$ Contrastes $=1$. efeito emurchecimento $(A+C$ vs. $B+D+E)$, 2. efeito enzimas - emurchecimento (A vs. C), 3. efeito enzimas - sem emurchecimento (B vs. $\mathrm{D}+\mathrm{E})$, 4. efeito do momento de aplicação da enzima (D vs. E).

Médias, na linha, seguidas de letras diferentes, para cada tratamento, são diferentes $(\mathrm{P}<0,05)$ pelo teste Tukey.

* Significativo a $5 \%$ de probabilidade , ** Significativo a $1 \%$ de probabilidade, $†$ Significativo a $10 \%$ de probabilidade. 
de forragem, ou mesmo compostas por ração completa, poderiam contribuir para redução do pH ruminal. Entretanto, essa justificativa não poderia ser considerada, em virtude de a silagem emurchecida controle apresentar, em comparação com todos os tratamentos, o maior valor de $\mathrm{pH}$.

A queda mais acentuada do $\mathrm{pH}$, com a aplicação das enzimas fibrolíticas em silagens emurchecidas (A vs. C), também poderia ser atribuída, inicialmente, ao aumento das taxas de fermentação e de digestão causadas pela adição das enzimas fibrolíticas associadas ao maior teor de carboidratos solúveis presentes na ração desses tratamentos. Essa queda de $\mathrm{pH}$, entretanto, não foi suficiente para acarretar impacto negativo na digestão da fibra, como constatado nos resultados apresentados na Tabela 9.

Vicini et al. (2003), avaliando o efeito de enzimas fibrolíticas ou açúcares solúveis e ácido málico em dietas para vacas leiteiras, relataram que o $\mathrm{pH}$ ruminal pode ser alterado pela quantidade de carboidratos solúveis na dieta. A recomendação sugerida para vacas leiteiras seria de 30 a 40\% de carboidratos solúveis, a fim de não correr riscos de acidose. Assim, é importante destacar que a dieta, neste experimento, foi calculada para apresentar 39\% de carboidratos solúveis, segundo o NRC (1996).

Lewis et al. (1996), observando o efeito de enzimas fibrolíticas em novilhos alimentados com uma dieta com 70\% de feno de gramínea e 30\% de cevada, também não verificaram interação entre o tempo e o tratamento no pH ruminal; contudo, no presente estudo, para todos os novilhos que receberam dietas tratadas com enzimas fibrolíticas, as médias foram mais baixas do que em dietas-controle (5,97 e 6,03, respectivamente). Além disso, quando a enzima foi aplicada diretamente ao concentrado no momento da alimentação, o valor de $\mathrm{pH}$ ruminal foi mais baixo, havendo tendência $(\mathrm{P}=0,15)$ de menores valores de $\mathrm{pH}$ nos tratamentos em que a enzima foi aplicada na forragem, 24 horas antes, ou no momento de fornecer ao animal.

De acordo com Firkins (1997), as melhores respostas para digestibilidade ruminal de FDN ocorrem em valores mais elevados de $\mathrm{pH}$ ruminal. Portanto, os resultados verificados no presente experimento, em relação ao $\mathrm{pH}$, indicam que as condições ruminais foram favoráveis ao melhor aproveitamento da fibra, uma vez que a atividade de organismos celulolíticos pode ser inibida em pH abaixo de 6,1 (Mould \& Orskov, 1983). 
Yang et al. (2002b) verificaram que existe significativa interação entre o pH e a presença de enzimas fibrolíticas na digestão da fibra e constataram pouco (8\%) acréscimo da digestibilidade do FDN, com a suplementação enzimática, quando a média do $\mathrm{pH}$ foi de 5,6. Todavia, quando o pH se apresentou acima de 6, o incremento da digestibilidade da fibra tornou-se bem mais pronunciado (18\%). Por meio desse experimento, conclui-se que a eficiência das enzimas fibrolíticas pode ficar comprometida em condições ruminais com baixo pH. Entretanto, McAllister et al. (2001) relataram que o pH ótimo para a atuação de enzimas fibrolíticas produzidas por fungos seria entre 4,0 e 6,0.

Embora a atividade celulolítica microbiana diminua com a redução de $\mathrm{pH}$, algumas preparações enzimáticas de celulase-hemicelulase apresentam ótima atividade enzimática fibrolítica em $\mathrm{pH}$ 4,5, caracterizando a especificidade da fonte enzimática (Pitt, 1990). Outro ponto importante a ser considerado, avaliando-se os benefícios da adição de enzimas fibrolíticas, é que estas podem também minimizar os efeitos depressivos da digestão da fibra durante períodos de queda do $\mathrm{pH}$.

Concentração molar de ácidos graxos voláteis, razão entre acetato e propionato e concentração total de ácidos graxos foram parâmetros avaliados em função do tempo. As variáveis que apresentaram efeito da interação tratamento*horário (Tabela 13) foram analisadas de acordo com os contrastes. Não foram detectadas diferenças significativas $(\mathrm{P}>0,10)$ para as concentrações dos ácidos graxos analisadas isoladamente em função do tratamento. Não houve efeito da interação tratamento*horário para as concentrações do acetato, ácido propiônico e do total de ácidos graxos.

A adição de enzimas fibrolíticas nas silagens emurchecidas (A vs. C) aumentou significativamente $(\mathrm{P}<0,05)$ a relação $\mathrm{C} 2 / \mathrm{C} 3$, de 4,07 para 4,31 mM, como mostra a análise do contraste (Tabela 13). Isso indica que a adição das enzimas poderia melhorar a digestão ruminal mesmo com a redução do $\mathrm{pH}$, agindo de forma associada com enzimas endógenas, aumentando o número de bactérias ruminais, ou agir de forma análoga, minimizando o efeito negativo da digestão da fibra em períodos de baixo $\mathrm{pH}$, como discutido anteriormente.

Com referência ao padrão de fermentação ruminal, pode-se verificar que a concentração molar média do total de ácidos graxos é de 109,62 mM. Em termos de 
proporções molares, os ácidos acético, propiônico, butírico, isobutírico, valérico e isovalérico representaram 69, 16, 11, 1, 0,89 e 1,5\%, respectivamente (Tabela 14). Tais resultados refletem um padrão de fermentação ruminal adequado para a manutenção da biodiversidade dos microrganismos do rúmen, sem comprometimento da digestibilidade da fibra. Geralmente as proporções molares de acetato, propionato e butirato variam de 75:15:10 a 40:40:20 (Bergman, 1990). Coelho (2002) relata, em seu experimento, que a proporção de 70:20:10 para esses respectivos ácidos reflete um padrão de fermentação ruminal típico de animais alimentados com volumosos.

Lewis et al. (1996) não verificaram efeito da adição de enzimas fibrolíticas quando aplicadas imediatamente ao alimento sobre a concentração dos ácidos graxos voláteis. No presente estudo, houve ausência de efeito das enzimas fibrolíticas, tanto para a concentração de ácidos graxos voláteis quanto para o total de ácidos graxos - resultados também observados por Feng et al. (1996). Contudo, uma das implicações do uso de enzimas fibrolíticas na dieta sobre os parâmetros de fermentação ruminal seria o aumento das taxas de fermentação da forragem e a capacidade de atender as exigências de proteína degradável no rúmen. Isso promoveria o aumento de energia disponível para os microrganismos ruminais, resultando em maior produção de ácidos graxos voláteis (Treacher e Hunt, 1996).

Quanto ao nitrogênio amoniacal, não houve diferença $(\mathrm{P}>0,10)$ entre os tratamentos aplicados na análise dos contrates (Tabela 13). Esses resultados estão de acordo, com exceção do pH, com Lewis et al. (1996) e Martins et al. (2002), que não constataram diferenças nos parâmetros ruminais ( $\mathrm{pH}$ e nitrogênio amoniacal) com suplementação enzimática. No entanto, esse fato contraria a expectativa da obtenção de maiores concentrações de nitrogênio amoniacal, devido ao aumento da taxa de digestão de nutrientes ocasionado pela adição de enzimas na dieta contendo silagem.

O valor médio de nitrogênio amoniacal foi de $5,6 \mathrm{mg} \mathrm{dL}^{-1}$ entre tratamentos, sendo essa concentração adequada para o máximo desenvolvimento dos microrganismos ruminais. Nesse sentido, Satter \& Slyter, (1974) mostraram, in vitro, que concentrações de nitrogênio amoniacal superiores a $5 \mathrm{mg} \mathrm{dL}^{-1}$ de fluido ruminal representariam um excesso para síntese microbiana. Apesar disso, há evidências de que maiores concentrações de 
nitrogênio amoniacal promoveram efeitos positivos no ambiente ruminal (Huber \& Kung, 1981).

\subsection{Evolução temporal da concentração do $\mathrm{pH}$, do nitrogênio amoniacal e da concentração total de ácidos graxos}

Os efeitos dos horários de coleta sobre os valores de $\mathrm{pH}$, nitrogênio amoniacal e concentração molar total de ácidos graxos do fluido ruminal estão apresentados nas Figuras 9, 10 e 11 e na Tabela 14. Nesse caso, é importante ressaltar que os animais foram alimentados duas vezes ao dia (às 8 e às 17 horas) e que a evolução diária apresentada se iniciou a partir da primeira refeição. Outra informação que deve ser considerada na avaliação dos resultados da evolução temporal dos parâmetros ruminais analisados é que $70 \%$ da ração foi fornecida durante a manhã, e os outros 30\%, à tarde.

Tabela 14. Evolução temporal das médias dos quadrados mínimos para os parâmetros ruminais observados em bovinos tratados com rações contendo silagens de capim Tanzânia com e sem adição de enzimas fibrolíticas

\begin{tabular}{cccccccccccc}
\hline \multicolumn{1}{c}{$\begin{array}{c}\text { Horário } \\
\text { de coleta }\end{array}$} & C2 & C3 & C4 & CI4 & C5 & CI5 & C2/C3 & TOTAL & $\begin{array}{c}\text { N- } \\
\text { amoniacal }\end{array}$ \\
\hline \multicolumn{10}{c}{ Concentração molar média de ácidos graxos voláteis (mM) } & & mg dL $^{-1}$ \\
\hline $02: 00$ & 84,43 & 20,02 & 13,26 & 0,96 & 0,95 & 1,52 & 4,24 & 121,14 & 6,18 & 2,93 \\
$04: 00$ & 84,76 & 19,38 & 13,01 & 0,97 & 0,96 & 1,68 & 4,39 & 120,76 & 6,17 & 2,77 \\
$06: 00$ & 83,78 & 19,37 & 12,68 & 1,10 & 1,00 & 1,85 & 4,35 & 119,78 & 6,37 & 3,32 \\
$08: 00$ & 64,94 & 14,82 & 9,84 & 1,16 & 0,77 & 1,80 & 4,40 & 93,33 & 6,87 & 6,35 \\
$10: 00$ & 58,85 & 13,43 & 9,95 & 1,15 & 0,96 & 1,76 & 4,39 & 86,11 & 6,89 & 11,25 \\
$12: 00$ & 69,11 & 15,16 & 12,00 & 1,19 & 1,07 & 1,79 & 4,54 & 100,33 & 6,68 & 9,15 \\
$14: 00$ & 69,20 & 15,41 & 11,55 & 1,00 & 1,00 & 1,49 & 4,50 & 99,66 & 6,47 & 5,89 \\
$16: 00$ & 73,55 & 16,78 & 12,15 & 0,98 & 0,96 & 1,45 & 4,38 & 105,87 & 6,28 & 5,57 \\
$18: 00$ & 78,41 & 17,76 & 13,55 & 1,05 & 1,13 & 1,40 & 4,41 & 113,64 & 6,38 & 7,18 \\
$20: 00$ & 78,07 & 18,77 & 13,28 & 0,89 & 1,03 & 1,37 & 4,18 & 113,36 & 6,06 & 5,22 \\
$22: 00$ & 84,80 & 19,94 & 13,67 & 0,84 & 0,99 & 1,37 & 4,27 & 121,61 & 5,92 & 3,39 \\
$00: 00$ & 83,26 & 19,68 & 13,60 & 0,91 & 0,97 & 1,50 & 4,24 & 119,93 & 6,07 & 3,13 \\
\hline
\end{tabular}


Com base nos resultados obtidos, observou-se que, provavelmente, a ração fornecida não tenha sido homogeneamente misturada, favorecendo a seleção do concentrado pelos animais ao longo das primeiras 14 horas de avaliação do pH ruminal daí a redução do pH. Além disso, é importante destacar que, segundo Keady \& Mayne (2001), quando o concentrado e a silagem são fornecidos em proporções iguais na dieta, a composição da silagem prevalece sobre os parâmetros da fermentação ruminal.

Observou-se, ainda, que o número de horas para a queda de $\mathrm{pH}$ é relativamente proporcional às quantidades fornecidas de ração tanto pela manhã quanto à tarde. Após esse intervalo de tempo, durante a noite, a porção representativa da dieta no cocho seria de silagem, o que parcialmente explicaria a tendência de elevação de $\mathrm{pH}$. Os picos de elevação do $\mathrm{pH}$ no fluido ruminal ocorreram entre uma hora e meia e duas horas após

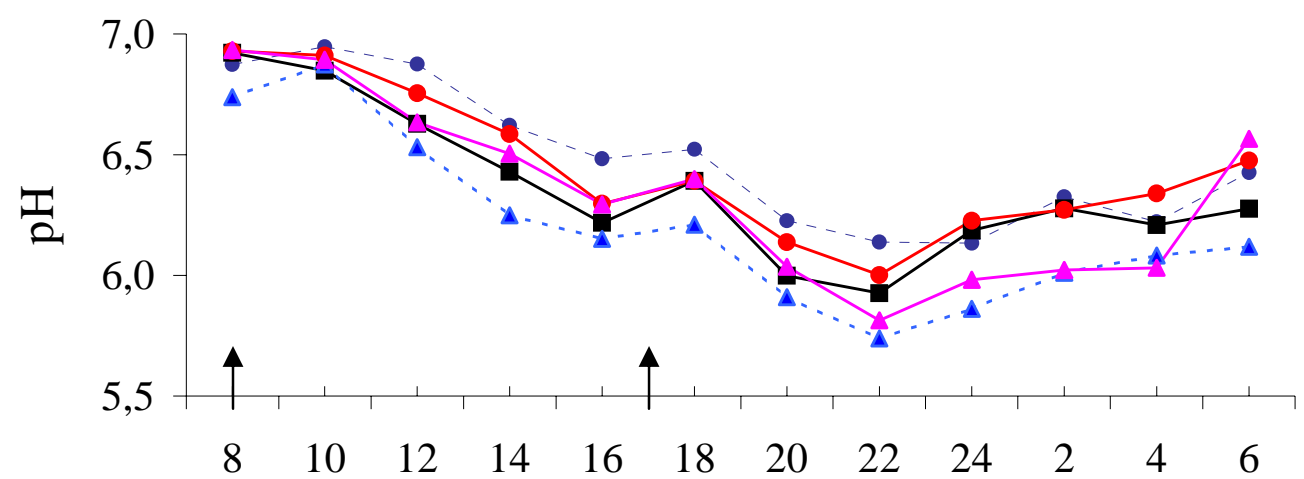

Horário de coleta (h)

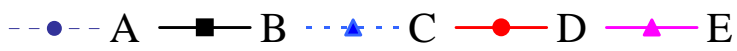

Os horários de fornecimento da dieta $(\uparrow)$.

Figura 9 - Efeito das dietas experimentais sobre a evolução temporal do pH no fluido ruminal 


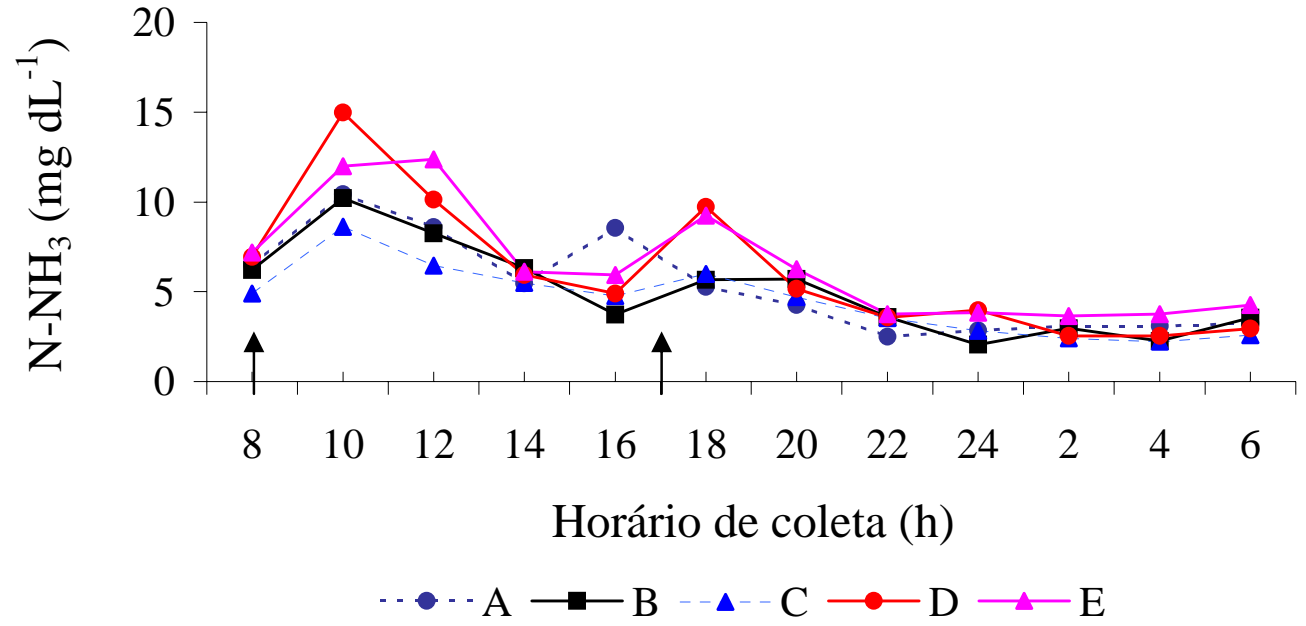

Os horários de fornecimento da dieta $(\uparrow)$.

Figura 10 - Efeito das dietas experimentais sobre a evolução temporal do nitrogênio amoniacal (mg dL $\left.{ }^{-1}\right)$

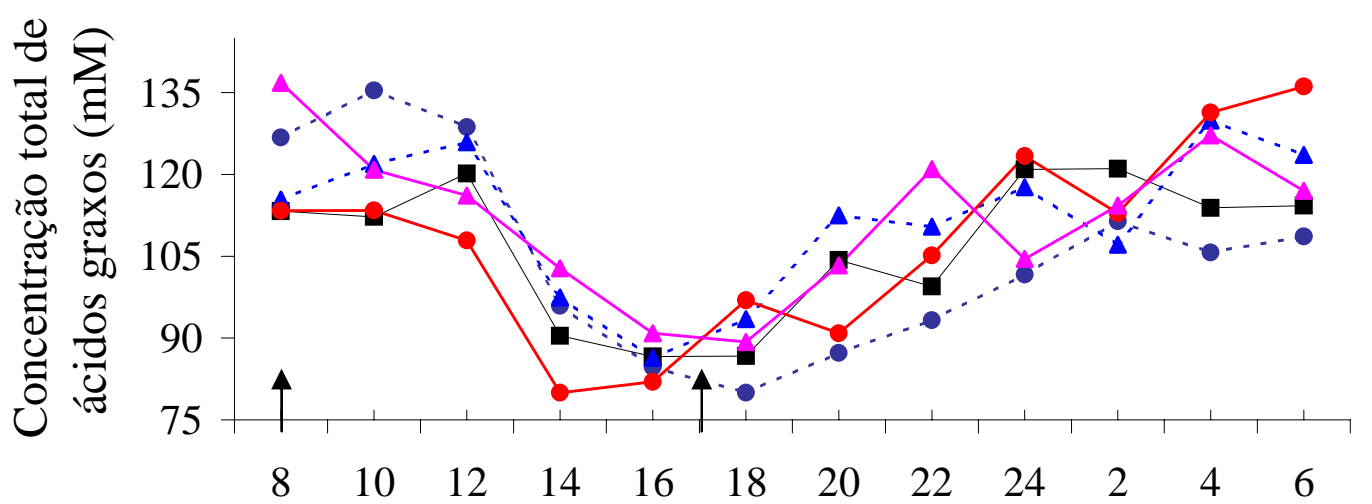

Horário de coleta (h)

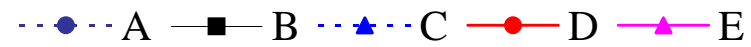

Os horários de fornecimento da dieta (个).

Figura 11 - Efeito das dietas experimentais sobre a evolução temporal da concentração total dos ácidos graxos voláteis 
alimentação, e as médias de $\mathrm{pH}$ ruminal dos tratamentos se mostraram sempre superiores a 5,5 no decorrer do dia.

Martins et al. (2002), apesar de não observarem diferença significativa nos valores de pH ruminal com adição de enzimas fibrolíticas em silagens de milho e feno de capim Tifton 85, obtiveram curva semelhante à verificada no presente experimento. O mesmo também pôde ser verificado ao analisar os dados de Lewis et al. (1996). Bowman et al. (2003), avaliando o efeito de enzimas fibrolíticas (xilanase e celulase) em dietas compostas de silagem de cevada e feno de alfafa, também não observaram efeito significativo sobre o pH ruminal com a suplementação enzimática.

Os resultados de elevação da concentração de nitrogênio amoniacal aparecem logo após o fornecimento da dieta, alcançando o máximo em uma a duas horas depois da ingestão (Figura 10). As concentrações médias de nitrogênio amoniacal no fluido ruminal das dietas variaram de 2,77 a 11,25 $\mathrm{mg} \mathrm{dL}^{-1}$ (Tabela 9). Da mesma forma, Coelho (2002) apresentou amplitudes de nitrogênio amoniacal da ordem de 3,68 a 10,83 $\mathrm{mg} \mathrm{dL}^{-1}$ em seu experimento, utilizando silagem de capim Tifton-85.

Analisando a curva da concentração total de ácidos graxos, constatou-se que, diferentemente do nitrogênio amoniacal e pH, o pico máximo de produção foi registrado mais tardiamente, com duas a três horas após a alimentação, conforme pode ser observado na Figura 9. Isso mostra que, além do nitrogênio e $\mathrm{pH}$, a produção de ácidos graxos voláteis também está relacionada à ingestão de alimento. O padrão da evolução temporal de ácidos graxos voláteis e de $\mathrm{pH}$ foi menos estável que aquele observado para o nitrogênio amoniacal. Entretanto, em todos os parâmetros ruminais analisados, houve tendência de maior pico após a alimentação no período da manhã, seguido de um menor pico após a alimentação da tarde.

Em geral, analisando os dados obtidos sobre os parâmetros ruminais avaliados, pode-se inferir que a adição de enzimas fibrolíticas na dieta de ruminantes não promoveu diferenças significativas na concentração de ácidos graxos voláteis, nitrogênio amoniacal e pH. Considerando que as condições do ambiente ruminal estiveram sempre favoráveis ao crescimento e à ação de microrganismos ruminais, todos os tratamentos impostos ofereceram condições adequadas para o processo de fermentação. 


\subsubsection{Digestibilidade aparente no trato digestivo}

$\mathrm{Na}$ análise da digestibilidade aparente no trato digestivo total, observou-se diferença significativa $(\mathrm{P}<0,01)$ para o efeito de emurchecimento da forragem, caracterizado pelo contraste 1, para as variáveis avaliadas: matéria seca, matéria orgânica, FDN, FDA e hemicelulose, conforme pode ser verificado na Tabela 15.

Dos contrastes entre os tratamentos testados, somente para os teores de FDN e FDA foram observados efeitos de momento da aplicação das enzimas fibrolíticas na silagem, com maiores valores de digestibilidade (58,21 vs. 51,99\% e 58,55\% vs. 50,79\%, respectivamente), quando se adicionou a solução enzimática na forragem 30 minutos antes do fornecimento desta aos animais. Esses resultados indicam que a aplicação da preparação enzimática minutos antes do fornecimento foi mais eficaz na elevação da digestibilidade aparente da fração fibrosa do que nos outros tratamentos impostos. Os resultados observados anteriormente, em relação à composição bromatológica das silagens, revelaram menores teores da fração fibrosa na silagem quando o complexo enzimático foi aplicado na ensilagem. Aparentemente, essa ocorrência poderia ser explicada por uma tendência característica dos resultados de forragens que receberam preparações enzimáticas, o que pode ser visto no tratamento $\mathrm{E}$, onde o tempo reduzido de contato entre o complexo enzimático e o substrato, provavelmente, impediu a ação completa das enzimas fibrolíticas, mantendo elevados os teores da fração fibrosa. No entanto, por não ter havido efetiva alteração nos componentes fibrosos (FDN e FDA), a porção mais digestível dessa fração foi mantida intacta ou pouco alterada; por isso, os maiores valores de digestibilidade do tratamento E em relação ao tratamento D. Em geral, nos experimentos contendo enzimas fibrolíticas, a maior efetividade desses complexos é caracterizada por redução na fração fibrosa e conseqüente diminuição da digestibilidade da fibra da forragem resultante (Kung Junior, 2000).

A aplicação da técnica de emurchecimento em forragens reduziu significativamente a digestibilidade da matéria orgânica em novilhos em crescimento (Yang et al., 2003). Portanto, a provável explicação para a diferença significativa entre 
Tabela 15. Quadrados mínimos para a digestibilidade e ingestão de nutrientes digestíveis para matéria seca, matéria orgânica, FDN, FDA e hemicelulose em bovinos que receberam rações contendo silagens de capim Tanzânia com e sem adição de enzimas fibrolíticas

\begin{tabular}{|c|c|c|c|c|c|c|c|c|c|c|}
\hline \multirow{2}{*}{ Variáveis } & \multicolumn{5}{|c|}{ Tratamentos $^{1}$} & \multirow{2}{*}{$\begin{array}{l}\text { CV } \\
(\%)\end{array}$} & \multicolumn{4}{|c|}{ Contrastes $(\mathrm{P}<)^{2}$} \\
\hline & A & B & $\mathrm{C}$ & $\mathrm{D}$ & $\mathrm{E}$ & & 1 & 2 & 3 & 4 \\
\hline \multicolumn{11}{|l|}{ Matéria seca } \\
\hline$\%$ & $46,08^{\mathrm{b}}$ & $53,25^{\mathrm{ab}}$ & $48,93^{\mathrm{ab}}$ & $52,28^{\mathrm{ab}}$ & $55,30^{\mathrm{a}}$ & 8 & $* *$ & 0,30 & 0,82 & 0,27 \\
\hline $\operatorname{kg} \operatorname{dia}^{-1}$ & $4,91^{\mathrm{a}}$ & $5,70^{\mathrm{a}}$ & $5,45^{\mathrm{a}}$ & $5,64^{\mathrm{a}}$ & $6,01^{\mathrm{a}}$ & 13 & $*$ & 0,25 & 0,75 & 0,41 \\
\hline \multicolumn{11}{|c|}{ Matéria orgânica } \\
\hline$\%$ & $45,72^{\mathrm{b}}$ & $55,67^{\mathrm{ab}}$ & $48,80^{\mathrm{ab}}$ & $54,93^{\mathrm{ab}}$ & $57,46^{\mathrm{a}}$ & 11 & $* *$ & 0,40 & 0,87 & 0,49 \\
\hline kg dia ${ }^{-1}$ & $4,41^{\mathrm{a}}$ & $5,50^{\mathrm{a}}$ & $4,91^{\mathrm{a}}$ & $5,43^{\mathrm{a}}$ & $5,78^{\mathrm{a}}$ & 17 & $*$ & 0,38 & 0,83 & 0,55 \\
\hline \multicolumn{11}{|l|}{ FDN } \\
\hline$\%$ & $45,74^{\mathrm{b}}$ & $54,74^{\mathrm{ab}}$ & $45,86^{\mathrm{b}}$ & $51,99^{\mathrm{ab}}$ & $58,21^{\mathrm{a}}$ & 9 & $* *$ & 0,97 & 0,89 & $*$ \\
\hline kg dia ${ }^{-1}$ & $2,50^{\mathrm{b}}$ & $3,14^{\mathrm{ab}}$ & $2,57^{\mathrm{ab}}$ & $2,95^{\mathrm{ab}}$ & $3,46^{\mathrm{a}}$ & 14 & $* *$ & 0,79 & 0,78 & $\dagger$ \\
\hline \multicolumn{11}{|l|}{ FDA } \\
\hline$\%$ & $45,36^{\mathrm{b}}$ & $55,06^{\mathrm{ab}}$ & $45,19^{b}$ & $50,79^{\mathrm{ab}}$ & $58,55^{\mathrm{a}}$ & 11 & $* *$ & 0,96 & 0,90 & $*$ \\
\hline kg dia ${ }^{-1}$ & $1,30^{\mathrm{a}}$ & $1,69^{\mathrm{a}}$ & $1,32^{\mathrm{a}}$ & $1,49^{\mathrm{a}}$ & $1,88^{\mathrm{a}}$ & 15 & $* *$ & 0,86 & 0,97 & $*$ \\
\hline \multicolumn{11}{|l|}{ Hemicelulose } \\
\hline$\%$ & $46,05^{\mathrm{a}}$ & $54,24^{\mathrm{a}}$ & $46,45^{\mathrm{a}}$ & $53,02^{\mathrm{a}}$ & $57,64^{\mathrm{a}}$ & 9 & $* *$ & 0,90 & 0,68 & 0,15 \\
\hline kg dia ${ }^{-1}$ & $1,20^{\mathrm{a}}$ & $1,45^{\mathrm{a}}$ & $1,24^{\mathrm{a}}$ & $1,45^{\mathrm{a}}$ & $1,58^{\mathrm{a}}$ & 15 & $* *$ & 0,75 & 0,54 & 0,33 \\
\hline \multicolumn{11}{|c|}{ 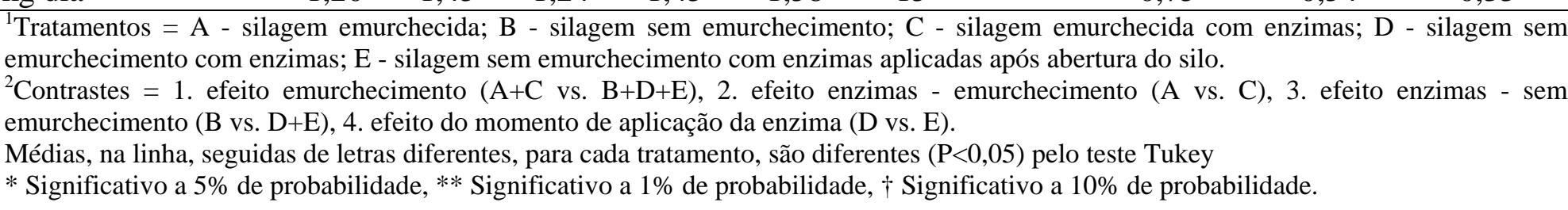 } \\
\hline
\end{tabular}


os valores obtidos das silagens emurchecidas e não-emurchecidas (47,27 e 56,01\%) está na alteração da solubilidade da fração de minerais da planta, decorrente do processo de desidratação da forragem no campo. O rompimento de células, ocorrido com o emurchecimento da forragem, poderia, ao menos parcialmente, explicar as variações de solubilidade dos minerais presentes na forragem fresca (Igarasi, 2002).

Lewis et al. (1996) verificaram aumentos na digestibilidade de MS, FDA e FDN em novilhos alimentados com ração contendo $70 \%$ de feno e $20 \%$ de cevada que receberam tratamento enzimático (24 horas antes ou no momento de serem fornecidas no cocho). Os valores médios obtidos para as digestibilidades de MS, FDN e FDA nas dietas com suplementação enzimática foram de 63,9; 59,4; e 56,9\%, respectivamente. Resultados semelhantes foram obtidos por Beauchemin et al. (1998) em dietas contendo altos níveis de solução enzimática, para a digestibilidade da matéria orgânica e FDN $(66,8$ e $43 \%)$.

Yang et al. (1997) observaram aumento da digestibilidade no trato digestivo total com a aplicação de enzimas fibrolíticas (pectinase, endocelulase e xilanase), minutos antes do fornecimento da dieta, para MO, PB, FDN e FDA. Em outro experimento, Yang et al. (1998), avaliando o efeito de enzimas fibrolíticas (xilanase e celulase) quando aplicadas sobre o concentrado, minutos antes do fornecimento da dieta, também verificaram aumentos significativos na digestibilidade de MS, FDN e FDA no trato digestivo em relação à dieta controle.

Segundo Treacher \& Hunt (1996), os valores obtidos para digestibilidade em dietas com enzimas fibrolíticas têm sido inconsistentes, especialmente quando eles estão relacionados ao desempenho animal. Esses autores observaram que alguns resultados positivos, em desempenho de animais, são alcançados mesmo sem alteração da digestibilidade; parte da explicação para esses dados estaria nas alterações das taxas de fermentação da forragem tratada com enzimas fibrolíticas, ocasionando interações com mudança das frações nitrogenadas, mais correlacionadas com os melhores desempenhos dos animais do que com alterações da digestibilidade do trato total. 


\subsubsection{Degradabilidade in situ}

\subsubsection{Degradabilidade da matéria seca}

Os resultados referentes à degradabilidade ruminal da matéria seca encontramse na Tabela 16. Quanto ao efeito de emurchecimento, o conteúdo da fração "a” das silagens emurchecidas mostrou-se superior ao da fração "a” das silagens nãoemurchecidas $(\mathrm{P}<0,01)$. Possivelmente, o maior conteúdo da fração rapidamente solúvel da MS, nas silagens emurchecidas, deve-se à menor perda de sólidos solúveis por efluente e a maior extensão do processo fermentativo das silagens com umidade original. Da mesma forma, as degradabilidades potencial e efetiva apresentaram-se inferiores nas silagens não-emurchecidas.

De acordo com Treacher \& Hunt (1996), avaliações do desaparecimento in situ da matéria seca em forragens, que sofreram tratamento enzimático, indicam que a fração de rápida solubilidade ("a”) e a fração potencialmente degradável ("b”) foram significativamente incrementadas; em fenos de alfafa, a degradabilidade efetiva foi reduzida de 76 para $65 \%$.

Foi verificado efeito significativo $(\mathrm{P}<0,01)$, no contraste 3 , entre silagens não emurchecidas (B vs. D+E) controle e com enzimas, na fração insolúvel, porém degradável, no rúmen, “b”, composta principalmente de parede celular. Adicionalmente, na avaliação de comparação entre médias pelo teste de Tukey, houve aumento de 4,88 unidades percentuais da fração "b” para silagens não-emurchecidas com enzimas (D), em relação ao controle (B). Quanto à comparação das degradabilidades potencial e efetiva, não houve diferença entre as silagens. Dessa forma, pode-se deduzir que não há diferença entre os tratamentos quanto ao potencial de utilização da silagem pelos animais.

Quanto ao efeito de adição de enzimas fibrolíticas, a análise de contraste mostra que não houve efeito significativo $(\mathrm{P}>0,10)$ para fração “a”; inclusive, para o tratamento D, observou-se valor negativo de “a”, o que pode ocorrer em algumas 
Tabela 16. Variáveis da degradabilidade in situ da matéria seca de silagens de capim Tanzânia com e sem adição de enzimas fibrolíticas

\begin{tabular}{|c|c|c|c|c|c|c|c|c|c|c|c|}
\hline \multirow{2}{*}{ Variáveis } & \multicolumn{5}{|c|}{ Tratamentos $^{1}$} & \multirow{2}{*}{$\begin{array}{l}\text { CV } \\
(\%)\end{array}$} & \multirow{2}{*}{ Médias } & \multicolumn{4}{|c|}{ Contrastes $(\mathrm{P}<)^{2}$} \\
\hline & $\mathrm{A}$ & $\mathrm{B}$ & $\mathrm{C}$ & $\mathrm{D}$ & $\mathrm{E}$ & & & 1 & 2 & 3 & 4 \\
\hline a (\%) & $5,56^{\mathrm{b}}$ & $1,62^{\mathrm{a}}$ & $4,76^{\mathrm{b}}$ & $-0,70^{\mathrm{a}}$ & $0,56^{\mathrm{a}}$ & 146 & 2,36 & $* *$ & 0,72 & 0,39 & 0,58 \\
\hline b (\%) & $62,62^{\mathrm{ab}}$ & $62,2^{\mathrm{b}}$ & $64,24^{\mathrm{ab}}$ & $67,08^{\mathrm{a}}$ & $64,8^{\mathrm{ab}}$ & 4 & 64,18 & 0,21 & 0,29 & $* *$ & 0,16 \\
\hline$c^{3}\left(\% h^{-1}\right)$ & $4,78^{\mathrm{a}}$ & $4,14^{\mathrm{a}}$ & $4,74^{\mathrm{a}}$ & $4,58^{\mathrm{a}}$ & $4,48^{\mathrm{a}}$ & 14 & 6,84 & 0,18 & 0,92 & 0,27 & 0,80 \\
\hline Degradabilidade potencial $^{4}(\%)$ & $68,20^{\mathrm{a}}$ & $63,86^{\mathrm{a}}$ & $69,02^{\mathrm{a}}$ & $66,4^{\mathrm{a}}$ & $65,38^{\mathrm{a}}$ & 4 & 66,57 & $* *$ & 0,66 & 0,22 & 0,58 \\
\hline Degradabilidade efetiva (\%) & $48,37^{\mathrm{ab}}$ & $43,10^{\mathrm{ab}}$ & $49,58^{\mathrm{a}}$ & $44,67^{\mathrm{ab}}$ & $42,85^{b}$ & 7 & 45,71 & $* *$ & 0,57 & 0,72 & 0,40 \\
\hline Lag Time (h) & $4,10^{\mathrm{a}}$ & $4,54^{\mathrm{a}}$ & $4,64^{\mathrm{a}}$ & $4,36^{\mathrm{a}}$ & $3,96^{\mathrm{a}}$ & 29 & 4,32 & 0,87 & 0,51 & 0,59 & 0,62 \\
\hline Tempo de retenção (h) & $45,13^{\mathrm{a}}$ & $46,98^{\mathrm{a}}$ & $48,43^{\mathrm{a}}$ & $44,52^{\mathrm{a}}$ & $41,82^{\mathrm{a}}$ & 13 & 45,38 & 0,34 & 0,39 & 0,25 & 0,48 \\
\hline Kp sólidos (\% hora $^{-1}$ ) & $2,22^{\mathrm{a}}$ & $2,15^{\mathrm{a}}$ & $2,08^{\mathrm{a}}$ & $2,29^{\mathrm{a}}$ & $2,43^{\mathrm{a}}$ & 12 & 2,23 & 0,27 & 0,44 & 0,20 & 0,44 \\
\hline
\end{tabular}

${ }^{1}$ Tratamentos = A - silagem emurchecida; B - silagem sem emurchecimento; C - silagem emurchecida com enzimas; D - silagem sem emurchecimento com enzimas; E - silagem sem emurchecimento com enzimas aplicadas após abertura do silo.

${ }^{2}$ Contrastes $=1$. efeito emurchecimento $(A+C$ vs. B+D+E), 2. efeito enzimas - emurchecimento (A vs. C), 3. efeito enzimas - sem emurchecimento (B vs. $\mathrm{D}+\mathrm{E})$, 4. Efeito do momento de aplicação da enzima (D vs E).

${ }^{3} \mathrm{Kd}=$ constante de degradação

${ }^{4}(\mathrm{a}+\mathrm{b})$

Médias, na linha, seguidas de letras diferentes, para cada tratamento, são diferentes $(\mathrm{P}<0,05)$ pelo teste Tukey.

* Significativo a $5 \%$ de probabilidade , ** Significativo a $1 \%$ de probabilidade. 
situações (Tabela 16). Os valores negativos para a fração “a” poderiam ser justificados pelo elevado erro experimental dessa mensuração, traduzido pelos valores de coeficientes de variação presentes nas Tabelas 16, 17, 18 e 19, que variaram de 70 a 195\%. Isso se deve aos resíduos não-uniformes resultantes da lavagem dos sacos de náilon, referentes ao tempo zero hora de incubação, utilizados na avaliação da fração solúvel em água. Adicionalmente, a reduzida concentração de componentes solúveis nessas silagens revela a possibilidade de distorções das equações de estimativa, as quais se tornam pouco precisas quando utilizadas para substratos fibrosos. Nas Tabelas 17, 18 e 19, os valores negativos para a fração "a” são ainda mais nítidos, uma vez que a fração fibrosa, provavelmente em quase sua totalidade, apresenta mínima contribuição de componentes solúveis; além disso, o tempo médio para o início da degradação da porção fibrosa ocorreu somente após seis horas de incubação (lag time).

A fração “a” se caracteriza por rápida taxa de degradação, que pode ocorrer devido aos fatores intrínsecos da forragem, ou mesmo por simples solubilidade (Thiago, 1994). Por se tratarem de amostras de forragem fermentada, por sofrer umedecimento prévio durante cinco minutos, intensa lavagem e manipulação dos sacos de náilon durante a realização do experimento, pode ter havido perda de material, o que fez com que os valores dessa fração de rápida degradação tenham sido muito variáveis em relação a outros estudos de degradabilidade in situ com gramíneas tropicais (Simili et al., 2002; Mello et al., 2002). Sampaio (1994) relatou que o umedecimento rápido dos sacos de náilon não afetaria as estimativas dos parâmetros da curva de degradação, porém a lavagem dos sacos com material causaria valores subestimados de “a” e “b”, sem alterar as taxas de degradação (fração “c”).

No entanto, os demais parâmetros avaliados, como fração "b”, fração “c”, degradabilidades potencial e efetiva, lag time e tempo de retenção, estão próximos aos valores observados por outros autores. Simili et al. (2002), avaliando a degradabilidade in situ da matéria seca do capim Tanzânia, verificaram valores de 16,30; 62,43; 78,73; e 59,18\% para as frações “a”, “b”, degradação potencial e degradação efetiva, respectivamente. Em experimento sobre a degradabilidade in situ da matéria seca do capim Tanzânia em diferentes estágios de maturidade, Mello et al. (2002) observaram efeitos 
significativos para as idades de corte. Mais especificamente para os valores de MS do capim Tanzânia com 50 dias, a fração “a” foi de 19,15\%; a fração “b”, de 52,59\%; a fração “c”, de 6,42\% $\mathrm{h}^{-1}$; e a degradação efetiva, de 48,66\%.

Considerando os dados avaliados para a degradação in situ da MS, pode-se verificar que os resultados então dentro daqueles encontrados na literatura e que a adição de enzimas fibrolíticas não aumentou o potencial de utilização da silagem de capim Tanzânia pelos animais. Todavia, o emurchecimento resultou em maiores valores para as degradabilidades potencial e efetiva da MS.

\subsubsection{Degradabilidade da fração fibrosa}

Os resíduos das amostras incubados no rúmen foram analisados quanto à percentagem de FDN, FDA e hemicelulose, para permitir calcular a degradabilidade efetiva da fração fibrosa na dieta, e as respectivas variáveis avaliadas quanto à degradação desta fração encontram-se nas Tabelas 17, 18 e 19, respectivamente.

Em razão da ausência do parâmetro percentagem das “perdas por lavagem” para inserir nos cálculos das variáveis da fração fibrosa, o programa "Fit Curve” forneceu duas alternativas: considerar este valor zero ou admitir o valor da degradabilidade da fibra do primeiro horário de incubação, ou seja, às 6 horas. Uma vez que os sacos de náilon com as amostras sofreram acentuada manipulação, incrementando o desvio-padrão das análises, e que provavelmente seria remota a possibilidade de adotar como nula as perdas por lavagem, optou-se pelo valor da degradabilidade do primeiro horário para ser considerado como a percentagem da fração eliminada pela lavagem.

Para os parâmetros avaliados das frações fibrosas - as degradabilidades potencial e efetiva - não foram verificados efeitos $(\mathrm{P}>0,10)$ de teor de $\mathrm{MS}$, aplicação das enzimas fibrolíticas ou momento de aplicação na forragem sobre as degradabilidades in situ (Tabelas 17, 18 e 19). Entretanto, em silagens de capim Tanzânia sem emurchecimento, a adição de enzimas fibrolíticas, antes do fornecimento ao animal, reduziu em 8 e 7 unidades percentuais a fração "b" para as degradabilidades in situ das frações FDN e FDA, respectivamente (Tabelas 17 e 18). 
Tabela 17. Variáveis da degradabilidade in situ da fibra em detergente neutro de silagens de capim Tanzânia com e sem adição de enzimas fibrolíticas

\begin{tabular}{|c|c|c|c|c|c|c|c|c|c|c|c|}
\hline \multirow{2}{*}{ Variáveis } & \multicolumn{5}{|c|}{ Tratamentos $^{1}$} & \multirow{2}{*}{$\begin{array}{l}\text { CV } \\
(\%)\end{array}$} & \multirow{2}{*}{ Médias } & \multicolumn{4}{|c|}{ Contrastes $(\mathrm{P}<)^{2}$} \\
\hline & A & B & $\mathrm{C}$ & $\mathrm{D}$ & $\mathrm{E}$ & & & 1 & 2 & 3 & 4 \\
\hline a (\%) & $-10,40$ & $-6,48$ & $-9,58$ & $-13,18$ & $-4,64$ & 66 & $-8,85$ & 0,44 & 0,83 & 0,46 & $*$ \\
\hline b (\%) & 76,46 & 70,48 & 76,14 & 78,92 & 71,04 & 7 & 74,60 & 0,19 & 0,92 & 0,12 & $*$ \\
\hline$c^{3}\left(\% h^{-1}\right)$ & 4,80 & 4,06 & 4,74 & 4,78 & 4,28 & 12 & 4,53 & $\dagger$ & 0,87 & 0,15 & 0,18 \\
\hline Degradabilidade potencial $^{4}(\%)$ & 66,08 & 63,24 & 66,56 & 65,74 & 66,40 & 5 & 65,60 & 0,35 & 0,80 & 0,11 & 0,73 \\
\hline Degradabilidade efetiva (\%) & 42,58 & 40,43 & 42,68 & 41,51 & 41,56 & 12 & 41,75 & 0,47 & 0,98 & 0,69 & 0,99 \\
\hline Lag time (h) & 6,24 & 6,28 & 6,24 & 5,84 & 6,24 & 9 & 6,17 & 0,62 & 1,00 & 0,46 & 0,30 \\
\hline Kp sólidos (\% hora $^{-1}$ ) & 2,22 & 2,15 & 2,08 & 2,29 & 2,43 & 12 & 2,23 & 0,27 & 0,44 & 0,20 & 0,44 \\
\hline
\end{tabular}

${ }^{1}$ Tratamentos = A - silagem emurchecida; $\mathrm{B}$ - silagem sem emurchecimento; C - silagem emurchecida com enzimas; D - silagem sem emurchecimento com enzimas; $\mathrm{E}$ - silagem sem emurchecimento com enzimas aplicadas após abertura do silo.

${ }^{2}$ Contrastes $=1$. efeito emurchecimento $(A+C$ vs. $B+D+E)$, 2. efeito enzimas - emurchecimento (A vs. C), 3. efeito enzimas - sem emurchecimento (B vs. $\mathrm{D}+\mathrm{E})$, 4. efeito do momento de aplicação da enzima (D vs. E).

${ }^{3} \mathrm{Kd}=$ constante de degradação.

${ }^{4}(\mathrm{a}+\mathrm{b})$

* Significativo a $5 \%$ de probabilidade , ** Significativo a $1 \%$ de probabilidade, $†$ Significativo a $10 \%$ de probabilidade. 
Tabela 18. Variáveis da degradabilidade in situ da fibra em detergente ácido de silagens de capim Tanzânia com e sem adição de enzimas fibrolíticas

\begin{tabular}{|c|c|c|c|c|c|c|c|c|c|c|c|}
\hline \multirow[b]{2}{*}{ Variáveis } & \multicolumn{5}{|c|}{ Tratamentos $^{1}$} & \multirow{2}{*}{$\begin{array}{l}\text { CV } \\
(\%)\end{array}$} & \multirow{2}{*}{$\begin{array}{l}\text { Média } \\
\text { s }\end{array}$} & \multicolumn{4}{|c|}{ Contrastes $(\mathrm{P}<)^{2}$} \\
\hline & A & B & $\mathrm{C}$ & $\mathrm{D}$ & E & & & 1 & 2 & 3 & 4 \\
\hline a $(\%)$ & $-14,86^{\mathrm{c}}$ & $-4,38^{\mathrm{ab}}$ & $-8,90^{\mathrm{abc}}$ & $-10,32^{\mathrm{bc}}$ & $-1,50^{\mathrm{a}}$ & 54 & $-7,99$ & $* *$ & * & 0,53 & $* *$ \\
\hline$b(\%)$ & $80,34^{\mathrm{a}}$ & $68,94^{\mathrm{b}}$ & $76,62^{\mathrm{ab}}$ & $76,70^{\mathrm{ab}}$ & $69,88^{\mathrm{b}}$ & 5 & 74,70 & $* *$ & 0,14 & 0,12 & $* *$ \\
\hline$c^{3}\left(\% h^{-1}\right)$ & $4,94^{\mathrm{a}}$ & $4,04^{\mathrm{a}}$ & $4,82^{\mathrm{a}}$ & $4,74^{\mathrm{a}}$ & $4,22^{\mathrm{a}}$ & 11 & 4,55 & $*$ & 0,72 & 0,14 & 0,14 \\
\hline Degradabilidade potencial $^{4}(\%)$ & $65,50^{\mathrm{a}}$ & $65,56^{\mathrm{a}}$ & $67,72^{\mathrm{a}}$ & $66,56^{\mathrm{a}}$ & $68,36^{\mathrm{a}}$ & 4 & 66,71 & 0,88 & 0,20 & 0,22 & 0,25 \\
\hline Degradabilidade efetiva (\%) & $41,32^{\mathrm{a}}$ & $42,04^{\mathrm{a}}$ & $43,93^{\mathrm{a}}$ & $42,64^{\mathrm{a}}$ & $43,75^{\mathrm{a}}$ & 9 & 42,74 & 0,91 & 0,31 & 0,60 & 0,66 \\
\hline Lag time (h) & $6,26^{\mathrm{a}}$ & $6,24^{\mathrm{a}}$ & $6,24^{\mathrm{a}}$ & $6,30^{\mathrm{a}}$ & $6,18^{\mathrm{a}}$ & 4 & 6,24 & 0,93 & 0,90 & 1,00 & 0,48 \\
\hline Kp sólidos (\% hora $^{-1}$ ) & $2,22^{\mathrm{a}}$ & $2,15^{\mathrm{a}}$ & $2,08^{\mathrm{a}}$ & $2,29^{\mathrm{a}}$ & $2,43^{\mathrm{a}}$ & 12 & 2,23 & 0,27 & 0,44 & 0,20 & 0,44 \\
\hline
\end{tabular}

${ }^{1}$ Tratamentos = A - silagem emurchecida; B - silagem sem emurchecimento; C - silagem emurchecida com enzimas; D - silagem sem emurchecimento com enzimas; $\mathrm{E}$ - silagem sem emurchecimento com enzimas aplicadas após abertura do silo.

${ }^{2}$ Contrastes $=1$. efeito emurchecimento $(A+C$ vs. $B+D+E)$, 2. efeito enzimas - emurchecimento (A vs. C), 3. efeito enzimas - sem emurchecimento (B vs. $\mathrm{D}+\mathrm{E})$, 4. efeito do momento de aplicação da enzima (D vs. E).

${ }^{3} \mathrm{Kd}=$ constante de degradação

${ }^{4}(\mathrm{a}+\mathrm{b})$

Médias, na linha, seguidas de letras diferentes, para cada tratamento, são diferentes $(\mathrm{P}<0,05)$ pelo teste Tukey.

Significativo a $5 \%$ de probabilidade , ${ }^{* *}$ Significativo a $1 \%$ de probabilidade. 
Tabela 19. Variáveis da degradabilidade in situ da hemicelulose de silagens de capim Tanzânia com e sem adição de enzimas fibrolíticas

\begin{tabular}{|c|c|c|c|c|c|c|c|c|c|c|c|}
\hline \multirow[b]{2}{*}{ Variáveis } & \multicolumn{5}{|c|}{ Tratamentos $^{1}$} & \multirow{2}{*}{$\begin{array}{l}\text { CV } \\
(\%)\end{array}$} & \multirow[b]{2}{*}{ Médias } & \multicolumn{4}{|c|}{ Contrastes $(\mathrm{P}<)^{2}$} \\
\hline & A & B & $\mathrm{C}$ & $\mathrm{D}$ & $\mathrm{E}$ & & & 1 & 2 & 3 & 4 \\
\hline a (\%) & $-7,07$ & $-7,70$ & $-12,00$ & $-8,64$ & 13,00 & 101 & $-7,89$ & 0,75 & 0,81 & 0,74 & 0,79 \\
\hline b (\%) & 71,30 & 70,45 & 77,0 & 74,4 & 63,50 & 15 & 72,76 & 0,42 & 0,59 & 0,32 & 0,39 \\
\hline$c^{3}\left(\% h^{-1}\right)$ & 4,96 & 4,65 & 3,50 & 4,96 & 3,80 & 15 & 4,55 & 0,95 & 0,86 & 0,33 & 0,25 \\
\hline Degradabilidade potencial $^{4}(\%)$ & 64,26 & 62,75 & 65,30 & 66,30 & 76,50 & 6 & 64,89 & 0,49 & 0,69 & 0,30 & 0,38 \\
\hline Degradabilidade efetiva (\%) & 41,09 & 39,42 & 41,35 & 43,60 & 39,42 & 10 & 40,97 & 0,82 & 0,93 & 0,38 & 0,14 \\
\hline Lag time (h) & 6,50 & 6,40 & 6,20 & 6,38 & 6,10 & 5 & 6,32 & 0,87 & 0,53 & 0,16 & 0,22 \\
\hline Kp sólidos (\% hora $\left.{ }^{-1}\right)$ & 2,22 & 2,15 & 2,08 & 2,29 & 2,43 & 12 & 2,23 & 0,27 & 0,44 & 0,20 & 0,44 \\
\hline
\end{tabular}

${ }^{1}$ Tratamentos = A - silagem emurchecida; B - silagem sem emurchecimento; C - silagem emurchecida com enzimas; D - silagem sem emurchecimento com enzimas; E - silagem sem emurchecimento com enzimas aplicadas após abertura do silo.

${ }^{2}$ Contrastes = efeito emurchecimento ( $+C$ vs. B+D+E), 2. efeito enzimas - emurchecimento (A vs. C), 3. efeito enzimas - sem emurchecimento (B vs $\mathrm{D}+\mathrm{E})$, 4. efeito do momento de aplicação da enzima (D vs. E).

${ }^{3} \mathrm{Kd}=$ constante de degradação.

${ }^{4}(\mathrm{a}+\mathrm{b})$ 
Não foi observada redução do lag time na fração hemicelulose com a aplicação enzimática sobre as silagens avaliadas. Contudo, em outro experimento, Yang et al (2000) constataram que o tratamento enzimático é capaz de reduzir o lag time quando as enzimas são aplicadas diretamente sobre o concentrado, mas o mesmo não ocorre quando essa aplicação é realizada sobre ração completa.

No presente estudo, o emurchecimento das silagens determinou valores mais elevados para as frações rapidamente solúveis da MS, bem como maiores degradabilidades potencial e efetiva. Para a aplicação de enzimas fibrolíticas, os resultados, em geral, mostraram-se sem efeitos significativos; o maior destaque ocorreu para o tratamento com adição de enzimas fibrolíticas minutos antes do fornecimento ao animal, que determinou a menor fração insolúvel potencialmente degradável para FDN e FDA, sem, contudo, alterar as degradabilidades efetivas e potenciais da fibra. Martins (2003) também não observou melhoria expressiva nos parâmetros ruminais em feno de capim Tifton 85, aos 30 dias de idade, com adição de enzimas fibrolíticas. Segundo o autor, isso poderia ter ocorrido devido à estabilidade da celulose cristalina do feno, que agiria limitando, de alguma forma, a ação de enzimas exógenas sobre a fibra.

Segundo Van Soest (1994), a digestão da fração hemicelulose é proporcional à digestão da celulose. No entanto, a maior parte da celulose é digerida no rúmen, enquanto parte substancial da hemicelulose escapa à degradação ruminal, sendo fermentada no intestino grosso (Ferreira et al., 1999). Não se conhece a razão de os grupos de arabinose não serem atacados no rúmen. Várias tentativas de explicação têm sido propostas para elucidar esse fenômeno, como a de que os grupos arabinofuranosil seriam sensíveis ao ambiente ácido do rúmen, ou o fato de as hemiceluloses ocorrerem como glicoproteínas hidrolisáveis pela pepsina ácida (Ely et al., 1956). Portanto, parte da ausência de resultados obtidos sobre a degradação in situ da hemicelulose poderia ser justificada por essas hipóteses apresentadas. 


\subsection{Conclusões}

A magnitude de variação observada nos parâmetros físico-químicos das silagens, decorrentes das práticas de emurchecimento, aplicação da solução enzimática e formas de aplicação não causaram efeitos consistentes nas variáveis de comportamento ingestivo e consumo voluntário em bovinos de corte.

A redução no conteúdo de FDN e FDA como resultado da aplicação de enzimas fibrolíticas, durante a ensilagem da forragem, não determinou alterações significativas nos parâmetros ruminais que viessem a contribuir para incrementar a ação dos microrganismos ruminais. A aplicação da preparação enzimática minutos antes do fornecimento da dieta proporcionou os melhores resultados sobre a digestibilidade da fração fibrosa, indicando que talvez essa forma de aplicação seja o método mais viável para garantir maior efetividade das enzimas fibrolíticas.

O estudo utilizando animais revelou-se fundamental na avaliação de aditivos e de práticas adotadas na ensilagem de capim Tanzânia, uma vez que foram demonstrados efeitos compensatórios que poderiam alterar a interpretação de resultados de fermentação da silagem e sugerir novas recomendações de manejo. 


\section{CONCLUSÕES GERAIS}

A redução do tamanho de partícula associada ao emurchecimento resultou em silagens de melhor valor nutricional, em virtude da redução das perdas e melhoria dos parâmetros fermentativos, o que vem enfatizar a importância dessas práticas no processo de conservação de forragens. As silagens de capim Tanzânia são susceptíveis às perdas cuja ocorrência e magnitude não são sincronizadas. Assim, a adoção de práticas de manejo direcionadas ao controle de perdas deverá considerar a associação de procedimentos e seus efeitos interativos.

A adição de enzimas fibrolíticas nas silagens promoveu redução da fração fibrosa, principalmente de hemicelulose, tanto em silagens emurchecidas quanto em não-emurchecidas, sendo sua eficiência mais acentuada nas primeiras. Todavia, não houve incremento na digestibilidade da matéria seca, confirmando os resultados obtidos no ensaio de digestibilidade com animais portadores de cânulas. A ausência de incrementos na digestibilidade com a redução da fração fibrosa pode estar associada às frações menos digestíveis da parede celular, como estruturas de complexos lignocelulolíticos. Assim, apesar de as enzimas fibrolíticas serem eficientes em liberar carboidratos solúveis, não atuariam da mesma forma na quebra de componentes fenólicos.

Considerando que não foram identificados aumentos significativos na digestão da fibra com a utilização de enzimas fibrolíticas, sugere-se que pesquisas futuras concentrem esforços na ampliação dos conhecimentos sobre a digestão dos complexos fibrosos das forragens. Há relatos na literatura sugerindo que a associação de enzimas fibrolíticas e amonização poderia ampliar a ação desse aditivo. 
A aplicação da preparação enzimática minutos antes do fornecimento da dieta proporcionou os melhores resultados sobre a digestibilidade da fração fibrosa, indicando que talvez essa forma de aplicação seja o método mais viável para garantir maior efetividade das enzimas fibrolíticas.

O estudo utilizando animais revelou-se essencial na avaliação de aditivos e de práticas adotadas na ensilagem de capim Tanzânia, visto que foram demonstrados efeitos compensatórios que poderiam alterar a interpretação de resultados de fermentação da silagem e sugerir novas recomendações de manejo. 


\section{REFERÊNCIAS BIBLIOGRÁFICAS}

AGUIAR, R. N. S.; CRESTANA, R. F.; BALSALOBRE, M. A. A.; NUSSIO L. G.; SANTOS P. M.; CORSI M. Avaliação das perdas de matéria seca em silagens de Tanzânia. In: REUNIÃO ANUAL DA SOCIEDADE BRASILEIRA DE ZOOTECNIA, 37. , Viçosa, 2000. Anais. Viçosa: SBZ, 2000. p.32.

AGUIAR, R. N. S.; CRESTANA, R. F.; BALSALOBRE, M. A. A., NUSSIO L. G.; SANTOS P. M.; CORSI, M. Efeito no tamanho de partícula na composição da fração nitrogenada de silagem de capim Tanzânia. In: REUNIÃO ANUAL DA SOCIEDADE BRASILEIRA DE ZOOTECNIA, 38. Piracicaba, 2001. Anais. Piracicaba: FEALQ, 2001. p.314-315.

AISAN, A.; OKAMOTO, M.; YOSHIHIRA, T.; ATAKU K.; NARASAKI, N. Effect of ensiling with Acremonium cellulase, lactic acid bacteria and formic acid on tissue structure of timothy and alfalfa. AJAS, v.10, n. 6, p.593-598, 1997.

ALLEN, M. S. Relationship between fermentation acid production in the rumen and the requirement for physically effective fiber. Journal of Dairy Science, v.80, p.14471462, 1997.

AMERICAN PUBLIC HEALTH ASSOCIATION - APHA. Standard Methods for the Examination of Water and Wastewater. 19. ed. Washington, DC: APHA, 1995, 1268p. 
ANIWARU, A.; ISHIDA, T.; WATANABE, T.; TOMIYAMA, K.; TERUI, H.; ATAKU, K.; CHASE, L. E. The effect of cellulase on cell wall structure and the rumen digestion of timothy silage (compact disc). In: INTERNATIONAL GRASSLAND CONGRESS, 19., São Pedro, 2001. Anais. Piracicaba: FEALQ, 2001 (Forage Conservation. Papers, ID 21-16).

ASSOCIATION OF OFFICIAL ANALYTICAL CHEMISTS - AOAC. Official Methods of Analysis. 12 ed. Washington, DC: AOAC, 1990. 1298p.

BALSAlOBRE, M. A. A.; NUSSIO, L. G.; MARTHA JÚNIOR., G. B. Controle de perdas na produção de silagens de gramíneas tropicais. Workshop sobre silagem. In: REUNIÃO ANUAL DA SOCIEDADE BRASILEIRA DE ZOOTECNIA, 38. Piracicaba, 2001. A produção animal na visão dos brasileiros. Piracicaba: FEALQ, 2001. p. 890-911.

BASTIMAN, B. Factors affecting silage effluent production. Experimental Husbandry, v. 31, p. 40-46, 1976.

BEAUCHEMIN, K. A.; BUCHANAN-SMITH, J. G. Effects of neutral detergent fiber concentration and supplementary long hay on chewing activities and milk production of dairy cows. Journal of Dairy Science, v.72, n 9, p.2288-2300, 1989.

BEAUCHEMIN, K. A.; RODE, L. M. The potential use of feed enzymes for ruminants. In: CORNELL NUTRITION CONFERENCE FOR FEED MANUFACTURERS. New York, 1996. Proceedings. New York: Rochester Marriott Thruway Hotel, 1996. p.131-141.

BEAUCHEMIN, K. A.; RODE, L. M.; SEWALT V. J. H. Fibrolytic enzymes increase fiber digestibility and growth rate of steers fed dry forages. Canadian Journal of Animal Science, v.75, p.641-644, 1995. 
BEAUCHEMIN, K. A.; W. Z. YANG; RODE, L. M. Effects of fibrolytic enzymes additives on extent of digestion and milk production of lactating cows. Journal of Animal Science, v.76, suppl. 1, p.358, 1998.

BEAUCHEMIN, K. A.; W. Z. YANG; RODE, L. M. Effects of grain source and enzymes additive on site and extent of nutrient digestion in dairy cows. Journal of Dairy Science, v.82, p.378-390, 1999.

BERGER, L. L.; FAHEY JUNIOR, G. C. Modification of forage quality after harvest. In: FAHEY JUNIOR, G. C. (Ed.). Forage quality, evaluation and utilization. Madison: ASA, CCSA, 1994. p.922-967.

BERGMAN, E. N. Energy contributions of volatile fatty acids from the gastrointestinal tract in various species. Physiological reviews. v.70, p. 567-590, 1990.

BERNARDES, T.F. Características fermentativas, microbiológicas e químicas do capimMarandu (Brachiaria brizantha (Hochst ex. A.Rich) Stapf cv. Marandu) ensilado com polpa cítrica peletizada. Jaboticabal, 2003. 108p. Dissertação (Mestrado) Faculdade de Ciências Agrárias e Veterinária, Universidade Estadual Paulista “Júlio de Mesquita Filho”.

BERTO, J. L.; MULHBACH; P. R. F. Silagem de aveia preta no estádio vegetativo, submetida a ação de inoculantes e ao efeito do emurchecimento. Revista Brasileira de Zootecnia, v.26, n.4, p.651-658, 1997.

BOYLES, D. W.; RICHARDSON, C. R.; COBB, C. W. Feedlot performance of steers fed steam-flaked grain sorghum with added enzymes. Journal of Animal Science, v.70, suppl. 1, p.131, 1992. 
BOWMAN, G R.; BEAUCHEMIN, K. A.; SHELFORD, J. A. Fibrolytic enzymes and parity effects on feeding behavior, salivation and ruminal $\mathrm{pH}$ of dairy cows. Journal of Dairy Science, v.86, p.565-575, 2002.

BOWMAN, G R.; BEAUCHEMIN, K. A.; SHELFORD, J. A. The proportion of the diet to which fibrolytic enzymes are added affects nutrient digestion by lactating dairy cows. Journal of Dairy Science, v.85, p.3420-3429, 2003.

BRAILE, P. M.; CAVALCANTE, J. E. W.A. Manual de tratamento de águas residuárias industriais. São Paulo: Companhia de Tecnologia de Saneamento Ambiental, 1993. 764p.

BRÂNCIO, P. A.; NASCIMENTO JR., D.; EUCLIDES, V. B. P.; REGAZZI, A. J.; ALMEIDA, R. G., FONSECA, D. M., BARBOSA, R. A. Avaliação de três cultivares de Panicum maximum Jacq. sob pastejo. Composição química e digestibilidade da forragem. Revista Brasileira de Zootecnia, v.31, n.4, p.16051613, 2002.

BROWN, K. M. Edgar experimental design generator and randomizer - Latin Squares. http://www.jic.bbsrc.ac.uk/services/statistics/latin.htm (11 Out. 2001)

BUSH, L.; BURTON, H Intrinsic chemical factors in forage quality. In: FAHEY JUNIOR, G. C. (Ed.). Forage quality, evaluation and utilization. Madison: ASA, CCSA. 1994. p.367-405.

BUXTON, D. R.; MERTENS D. R. Quality related characteristics of forages. In: BARNES, F. R.; MILLER, D. A. NELSON, C. J. (Ed.). Forages: The Science of Grassland Agriculture, 5 ed. Iowa: Iowa State University Press, v. 2, p.83-96, 1995. 
CASTLE, M. E., WATSON, J. N. The relationship between the DM content of herbage for silage making and effluent production. Journal of the British Grassland Society, v. 28, p. 135-138, 1973.

CASTRO, F. G. Uso de pré-emurchecimento, inoculante bacteriano-enzimático ou ácido propiônico na produção de silagem de Tifton-85 (Cynodon sp). Piracicaba, 2002.136p. Tese (Doutorado) - Escola Superior de Agricultura “Luiz de Queiroz”, Universidade de São Paulo.

CHANEY, A L.; MARBACH, E. P. Modified reagents for determination of urea and ammonia. Clinical Chemistry, v. 8, n.2, p.130-137, 1962.

CHEN, J., STOKES, M. R. WALLACE, C R. Effect of enzyme-inoculant systems on preservation and nutritive value of haycrop and corn silage. Journal of Dairy Science, v.77, p.501-512, 1994.

CHENG, K. H; HUBER, J. T.; SIMAS, J., THEURER, C. B.; YU, P.; CHAN, S.C.; SANTOS, F.; WU, Z. Effect of enzyme treatment or steam-flaking of sorghum grain on lactation and digestion in dairy cows. Journal of Dairy Science, v.78, p.1721, 1995.

COELHO, R. M. Efeito da concentração de matéria seca e do uso de inoculante bacteriano-enzimático, na silagem de Tifton-85 (Cynodon ssp.), sobre a digestão de nutrientes, parâmetros ruminais e comportamento ingestivo em novilhos de corte em crescimento. Piracicaba, 2002. 136p. Dissertação (Mestrado) - Escola Superior de Agricultura “Luiz de Queiroz”, Universidade de São Paulo.

COLOMBATTO, D; BHAT, M. K.; MOULD F. L.; OWEN, E. Characterization and evaluation of a commercial enzyme nutritive value of ruminant feeds. Proceedings of the British Society of Animal Science, p.211, 1999. 
COLOMBATTO, D; MOULD F. L.; BHAT, M. K.; PHIPPS, R. H.; OWEN, E. In vitro evaluation of fibrolytic enzymes as additives for maize (Zea mays L.) silage - I. Effects of ensiling temperature, enzyme source and addition level. Animal Feed Science and Technology, v. 111, p.111-128, 2004a.

COLOMBATTO, D; MOULD F. L.; BHAT, M. K.; PHIPPS, R. H.; OWEN, E. In vitro evaluation of fibrolytic enzymes as additives for maize (Zea mays L.) silage - II Effects on rate of acidification, fibre degradation during ensiling and rumen fermentation. Animal Feed Science and Technology, v. 111, p.129-143, 2004b.

COLOMBATTO, D; MOULD F. L.; BHAT, M. K.; PHIPPS, R. H.; OWEN, E. In vitro evaluation of fibrolytic enzymes as additives for maize (Zea mays L.) silage - III Comparison of enzymes derived from psychrophilic, mesophilic or thermophilic sources. Animal Feed Science and Technology, v. 111, p.145-159, 2004c.

COLUCCI, P. E.; MACLEOD, G. K.; GROVUM, W. L.; McMILLAN, I.; BARNEY, D. J. Digesta kinetics in sheep and cattle fed diets with different forage to concentrate ratios at high and low intakes. Journal of Dairy Science, v.73, p.2143-2156, 1990.

COPAM. Legislação ambiental. 3. ed. Belo Horizonte: Imprensa Oficial, 183p. 1986.

DHIMAN, T. R.; ZAMAN M. S.; GIMENEZ, R. R.; WALTERS, J. L.; TREACHER, R. Performance of dairy cows fed forage treated with fibrolytic enzymes prior to feeding. Animal Feed Science and Technology, v. 101, p.115-125, 2002.

DUBOIS, M. K.; GILlES, K. A.; HAMILTON, J. K.; REBERS, P. A.; SMITH, F. Colorimetric method for determination of sugars and related substances. Analytical Chemistry, v.28, p. 350-356, 1956. 
ELY, R. E. MELIN, C. G.; MOORE, L. A. Yields and protein content of holocellulose prepared from pepsin-treated forages. Journal of Dairy Science, v.39, p.1742-1756, 1956.

FAHEY, G. C., JUNIOR.; BOURQUIN L. D., TITGEMEYER, E. C.; ATWELL, D. G. Postharvest treatment of fibrous feedstuffs to improve their nutritive value. In: JUNG, H. G.; HATFIELD, R. D.; RALPH, J. e BUXTON, D. R. (Ed.). Forage cell wall structure and digestibility. Madison: ASA-CSSA-SSSA, 1994. p.715-766.

FEAM. Licenciamento ambiental: Coletânea de legislação. In: Manual de saneamento e proteção ambiental para municípios. Belo Horizonte: FEAM, 1998. 382 p.

FENG, P.; HUNT, C. W.; PRITCHARD, G. T.; JULIEN, W. E. Effect of enzyme preparations on in situ and in vivo additives degradation and in vivo digestive characteristic of mature cool-season grass forage in beef steers . Journal of Animal Science, v.74 (6), p.1349-1357, 1996.

FENG, P.; HUNT, C. W.; JULIEN, W. E.; DICKENSON, K.; MOEN, T. Effect of enzymes additives on in situ and in vitro degradation of mature cool-season grass forage. Journal of Animal Science, v.70, suppl. 1, p.309, 1992.

FERREIRA, F. M. A.; FONTES, C. A. FERNANDES, T. H. A fibra em nutrição animal. Revista Portuguesa de Ciências Veterinárias, v.94, n. 531, p.119-130, jul/set, 1999.

FIRKINS, J. L. Effects of feeding nonforage fiber sources on site of digestion. Journal of Dairy Science, v.80, p.1426-1437, 1997. 
FIRKINS, J. L; BERGER, L. L.; MERCHEN, N. R.; FAHEY JUNIOR, G. C.; NELSON, D.R. Effects of feed intake and protein degradability on ruminal characteristics and site of digestion in steers. Journal of Dairy Science, v.86, p.2111-2123, 1996.

FONTES, C. M; HALL J.; HIRST, B. H.; HASLEWOOD, G. P; GILBERT H. J. The resistance of cellulases and xylanases to proteolytic inactivation. Applied Microbiology and Biotechnoly, v.43, p.52-57, 1995.

FONTES, C. A. FERNANDES, T. H., FERREIRA, L.M.A. Estratégias de degradação biológica da celulose e hemiceluloses. Revista Portuguesa de Ciências Veterinárias, v.91, n. 519, p.106-115, jul/set, 1996.

GALANOS, E.; GRAY, K. R.; BIDDLESTONE, A. J.; THAYANITHY, K. The aerobic treatment of silage effluent: effluent characterization and fermentation. Journal of Agricultural Engineering Research, v.62, p.271-279, 1995.

GIGER-REVERDIN，S.; DUVAUX-PONTER, C.; SAUVANT, D.; MARTIN, O; PRADO, I. N. e MÜLLER R. Intrinsic buffering capacity of feedstuffs. Animal Feed Science and Technology, v. 96, p.83-102, 2002.

GLEN, B. P.; WALDO, D. R. Cell wall degradation in ruminant - session synopsis. In: JUNG, H. G.; HATFIELD, R. D.; RALPH, J. e BUXTON, D. R. (Ed.). Forage cell wall structure and digestibility. Madison: ASA-CSSA-SSSA, 1994. p.603-683.

GORDON, C. H., WISEMAN, H. G., DERBYSHIRE, J. C., JACOBSON, W. C. Effect on silage of chopping and bruising the forage. Journal of Dairy Science, v. 42, p.1394, 1958.

GRANT, R. J. Interactions among forages and nonforage fiber source. Journal of Dairy Science, v. 80, p.1438-1446. 1997. 
GREENHILL, W.L. Plant juice in relation to silage fermentation. I The role of the juice. Journal of the British Grassland Society, v.19, p. 30-37, 1964.

GUIM, A.; ANDRADE, P.; ITURRINO-SCHOKEN, R. P.; FRANCO, G. L.; RUGGIERI, A. C.; MALHEIROS, E. B. Estabilidade aeróbica de silagens de capimelefante (Pennisetum purpureum, Schum.) emurchecido e tratado com inoculante microbiano. Revista Brasileira de Zootecnia, v.31, n.6, p.2176-2185, 2002.

HAIGH, P. M. Silage dry matter content and silage additives on the fermentation of bunker-made grass silages on commercial farms in Wales 1987-1993. Journal of Agricultural Engineering Research, v.64, n.1, p.261-270. 1996.

HAIGH, P.M. Effect of additives on grass silage fermentation and effluent production, and on intake and liveweight change of young cattle. Journal of Agricultural Engineering Research, v. 69, p.141-148. 1998.

HAIGH, P.M. Effluent production from grass silage treated with additives and in largescale bunker silos. Grass and Forage Science, v.54, p.208-218. 1999.

HARRISON, J. H.; BLAUWIEKEL, R.; STOKES, M. R. Symposium: Utilization of grass silage - fermentation and utilization of grass silage. Journal of Dairy Science, v. 77, p.3209-3235. 1994.

HENDERSON, N. Silage additives. Animal Feed Science and Technology, v. 45, p.3556, 1993. 
HENRIQUES, L. T.; da SILVA, J. F. C.; VÁSQUES, H. M.; ARAÚJO, G. G. L.; BARROS, E. E. L.; CECON, P. R.; GOMES, H.L. Efeito do acipin sobre a degradabilidade e a taxa de passagem de silagens de capim elefante e de milho, em bovinos mestiços holandês x zebu. In: REUNIÃO ANUAL DA SOCIEDADE BRASILEIRA DE ZOOTECNIA, 38. , Piracicaba, 2001. Anais. Piracicaba: FEALQ, 2001. p.1321-1322.

HIGGINBOTHAM, G. E.; DEPETERS, E. J.; BERRY, S. L.; AHMADID A. Effect of adding a cell wall degrading enzyme to a total mixed ration for lactating cows. The Professional Animal Scientist, v.12, p. 81-85, 1994.

HIRSTOV, A. N.; McAlLISTER, T. A.; TREACHER, R. J.; CHENG, K. J. Stability of exogenous polysaccharide-degrading enzymes in the rumen. Journal of Animal Science, v.75, suppl. 1, p.120, 1997.

HOLDEN, L. A. Comparison of methods of in vitro dry matter for ten feeds. Journal of Dairy Science, v.82, n. 8, p.1791-1794, 1999.

HUBER, J. T.; KUNG, L. Protein e nonprotein utilization in cattle. Journal of Dairy Science, v.64, n. 6, p.1170-1195, 1981.

IGARASI, M. S. Controle de perdas na ensilagem de capim Tanzânia (Panicum Maximum Jacq. cv Tanzânia) sob os efeitos do teor de matéria seca, do tamanho de partícula, da estação do ano e da presença do inoculante bacteriano. Piracicaba, 2002. 132p. Dissertação (Mestrado) - Escola Superior de Agricultura “Luiz de Queiroz”, Universidade de São Paulo. 
ISHIDA, T.; AISAN, A.; TOMIYAMA, K.; WATANABE, T.; TERUI, H.; ATAKU, K. The effect of cellulase on cell wall structure and the rumen digestion of alfalfa silage (compact disc). In: INTERNATIONAL GRASSLAND CONGRESS. 19., São Pedro, 2001. Anais. Piracicaba: FEALQ, 2001 (Forage Conservation. Papers, ID 21-17).

JASTER, E. H. Legume and grass silage preservation. In: MOORE, K J.; KRAL, D. M.; VINEY, M. K. Post-harvest physiology and preservation of forage. Madison: ASA, CCSA, 1995. p.91-115.

JACOBS, J. L.; HAINES, M. J.; McALLAN, A. B. The effects of different protein supplements on the utilization of untreated, formic acid-treated or enzyme-treated silages by growing steers. Grass and Forage Science, v.47, n.2, p.121-127. 1992.

JONES, D. I .H.; JONES, R. The effect of crop characteristics and ensiling methodology on grass silage effluent production. Journal of Agricultural Engineering Research, v. 60, p.73-81, 1995.

JUNG H. G.; ALLEN S. Characteristics of plant cell walls affecting intake and digestibility of forages by ruminants Journal of Animal Science, v.73, p.27742790, 1995.

KEADY, T. W. J.; MAYNE, C. S. The effect of concentrate energy source on feed intake and rumen fermentation parameters of dairy cows offered a range of grass silages. Animal Feed Science and Technology, v.90, p.117-129, 2001.

KNOWLTON, K. F.; McKINNEY, J M. COBB, C. Effect of a direct-fed fibrolytic enzyme formulation on nutrient intake, partitioning, and excretion in early and late lactation Holstein cows. Journal of Dairy Science, v.85, p.3328-3335, 2002. 
KRAUS, T. J.; KOEGEL, R. G.; STRAUB, R. J.; SHINNERS, K. J. Leachate conductivity as an index for quantifying level of forage conditioning. In: ASAE ANNUAL INTERNATIONAL MEETING. Minneapolis, 1997. Proceedings. Minneapolis: ASAE, 1997. p.1-12.

KUNG, L. JUNIOR. A review on silage additives and enzymes. http:/ag.udel.edu/ departments/anfs/faculty/kung/articles/a_review_on_silage_additives_and.htm. (18 Jul. 1997)

KUNG, L. JUNIOR. Aditivos microbianos e químicos para silagem - Efeitos na fermentação e resposta animal. In: WORKSHOP SOBRE MILHO PARA SILAGEM, 2. , Piracicaba, 2000. Anais. Piracicaba: FEALQ, 2001. p.53-73.

KUNG, L. JUNIOR; MUCK, R. E. Animal response to silages additives. In: THE SILAGE: FIELD TO FEED BUNK NORTH AMERICAN CONFERENCE. Hershey, 1997. Proceedings. Hershey: National Regional Agricultural Engineering Service. 1997. p. 200-209.

KUNG, L. JUNIOR; GRIEVE, D. B.; THOMAS, J. W. HUBER, J. T. Added ammonia or microbial inocula for fermentation and nitrogenous compounds of alfalfa ensiled at various percents of dry matter. Journal of Dairy Science, v.67, n.2, p. 299-306, 1984.

KUNG, L. JUNIOR.; COHEN, M. A.; RODE, L. M.; TREACHER, R. J. The effect of fibrolytic enzymes sprayed onto forages and fed in a total mixed ratio to lactating dairy cows. Journal of Dairy Science, v.85, p.2396-2402, 2002. 
KUNG, L. JUNIOR.; TREACHER, R. J.; NAUMAN, G. A.; SMAGALA, A. M.; ENDRES, K. M.; COHEN, M. A. The effect of treating forages with fibrolytic enzymes on its nutritive value and lactation performance of dairy cows. Journal of Dairy Science, v.83, p.115-122, 2000a.

KUNG, L. JUNIOR.; LAZARTIC, J.; WUERFEL, R. L.; RODE, K. A.; BEAUCHEMIN, K. A.;TREACHER, R. J. The effect of various combinations of fibrolytic enzymes on the feeding value of a TMR fed to lactating cows. Journal of Dairy Science, v. 83, suppl. 1, p.297, 2000 b.

KUSS, A. V. Avaliação da ensilagem de Lolium multiflorum (azevém) em microsilos: efeito da adição de inoculante bacteriano e enzimas celulolíticas. Caxias do Sul, 2001. 136p. Dissertação (Mestrado) - Universidade de Caxias do Sul.

LAMMERS, B. P.; BUCKMASTER, D. R.; HEINRICHS, J. A simple method for the analysis of particle sizes of forage and total mixed rations. Journal of Dairy Science, v.79, n.5, p.922-928, 1996.

LAVEZZO, W. Silagem de capim elefante. Informe Agropecuário, v.11, p.50-56, 1985.

LEWIS, G. E.; HUNT, C. W.; SANCHEZ, W. K.; TREACHER, R.; PRITCHARD, G. T.; FENG, P. Effect of direct-fed fibrolytic enzymes on the digestive characteristics of a forage-based diet fed to beef steers. Journal of Animal Science, v. 74, p.30203028, 1996.

LEWIS, G. E.; SANCHEZ, W. K.; HUNT, C. W.; GUY M. A.; PRITCHARD, G.; PRITCHARD, B. I.; TREACHER, R. J. Effect of direct-fed fibrolytic enzymes on the lactational performance of dairy cows. Journal of Animal Science, v. 82, p.611617, 1999. 
LOURES, D. R. S. Características do efluente e composição químico-bromatológica da silagem sob níveis de compactação e de umidade do capim-elefante (Pennisetum purpureum Schum.) cv. Cameroon. Viçosa, 2000. 67p. Dissertação (Mestrado) Universidade Federal de Viçosa.

LUCHINI, N. D.; BRODERICK, G. A.; HEFNER, D. L.; REYNAL, S.; TREACHER, R. Production response to treating forage with fibrolytic enzymes prior to feeding to lactating cows. Journal of Dairy Science, v.80, suppl. 1, p.262, 1997.

MAEKAWA, M; BEAUCHEMIN, K. A.; CHRISTENSEN, D. A. Chewing activity, saliva production, and ruminal $\mathrm{pH}$ of primiparous and multiparous lactating dairy cows. Journal of Dairy Science, v.85, p.1176-1182, 2002.

MAGALHÃES, V. J. A. Efeitos da inoculação da silagem pré-secada de alfafa sobre a fermentação no silo, digestibilidade e desempenho produtivo de vacas leiteiras. Pirassununga, 2002. 106p. Dissertação (Mestrado) - Faculdade de Medicina Veterinária e Zootecnia, Universidade de São Paulo.

MAHANNA, B. Troubleshooting silages problems. In: STATE APPLIED NUTRITION CONFERENCE, 4., LaCrosse, 1993, Proceedings. LaCrosse: Pioneer Hi-bred International, 1993. p.1-21.

MAKI, S. P.; JOHNSON, K. A.; HUNT, C. The effect of direct-fed fibrolytic enzymes on the digestibility on dry-rolled and tempered barley. Journal of Animal Science, v.76, suppl. 1, p.320, 1998.

MANDEBVU, P.; WEST, J. W.; GATES, R. N.; FROETSCHEL, M. A.; HILL, G. M. Effect of enzymes or microbial treatment of bermudagrass forages before ensiling on nutrient composition and digestion. http://www.ads.uga.edu/annrpt/ 1997/97_151. (18 Jul. 1997a) 
MANDEBVU, P.; WEST, J.W.; GATES, R.N; FROETSCHEL, M.A.; HILL, G.M. Effect of enzymes or microbial treatment of bermudagrass forages before ensiling on nutrient composition, recovery and digestion. Journal of Dairy Science, v.80, suppl. 1, p.220, 1997b.

MANDEBVU, P.; WEST, J. W.; HATFIELD, R. D.; HILL, G. M.; FROETSCHEL, M. A.; GATES, R.. N. Effect of treating bermudagrass forages at ensiling with fibrolytic enzymes or microbial inoculant on carbohydrate content of cell walls, concentrations of p-coumaric and ferulic acids, and in situ digestion. Journal of Dairy Science, v.76, suppl. 1, p.198, 1998.

MANDEBVU, P.; WEST, J.W.; FROETSCHEL, M. A.; HATFIELD, R.D.; GATES, R.N; HILL, G.M. Effect of enzymes or microbial treatment of bermudagrass forages before ensiling on cell wall composition, end products of silage fermentation and in situ digestion kinetics. Animal Feed Science and Technology, v. 77, p.317-329, 1999.

MARI, L. J. Intervalo entre cortes em capim-marandu (Brachiaria brizantha (Hochts. ex A. Rich.) Stapf cv. Marandu): produção, valor nutritivo e perdas associadas à fermentação da silagem.Piracicaba, 2003. 138p. Dissertação (Mestrado) - Escola Superior de Agricultura “Luiz de Queiroz”, Universidade de São Paulo.

MARQUARDT, R. R.; BRENES, A.; ZHANG, Z.; BOROS, D. Use of enzymes to improve nutrient availability in poultry feedstuffs. Animal Feed Science and Technology, v. 60, p.321-330, 1996.

MARTINS, A. S. Enzimas fibrolíticas exógenas na alimentação de bovinos. Jaboticabal, 2003. 125p. Tese (Doutorado) - Faculdade de Ciências Agrárias e Veterinária, Universidade Estadual Paulista “Júlio de Mesquita Filho”. 
MARTINS, A. S.; BERCHIELLI, P. F.V.; PRADO, I. N.; CANESIN, R. C.; SETTI, M. C. Efeito da adição de enzimas fibrolíticas à ração sobre os parâmetros ruminais em bovinos alimentados com silagem de milho e feno de Tifton 85 (compact disc). In: REUNIÃO ANUAL DA SOCIEDADE BRASILEIRA DE ZOOTECNIA, 39. , Recife, 2002, Anais. Recife: Ed. dos Editores, 2002.

MEESKE, R.; BASSON, H. M.; CRUYWAGEN. The effect of a lactic acid bacterial inoculant with enzymes on the fermentation dynamics, intake and digestibility of Digitaria eriantha silage. Animal Feed Science and Technology, v. 81, p.237-248, 1999.

McDONALD, P. The biochemistry of silage. New York: John Wiley, 1981. 207p.

McDOnALD, P.; HENDERSON, A.R.; HERON, S. J. E. The Biochemistry of Silage. 2.ed. Marlow: Chalcombe, 1991. 340 p.

McAllisteR, T. A.; HIRSTOV, A. N.; BEAUCHEMIN, K. A.; RODE, L. M.; CHENG, K. J. Enzymes in ruminants diets. http://www.cabi-publishing.org/ Bookshop/Readingroom/0851993931/3931ch11.pdf. (15 Jan. 2001).

MELlO, S. Q. S.; ALVES, J. B.; BERGAMASCHINE, A. F.; FREITAS, R. V. L.; MATSUMOTO, E.; BASTOS, J. F. P. Degradabilidade in situ da matéria seca e da fibra em detergente neutro de cultivares de Panicum maximun Jacq. em três estágios de maturidade (compact disc). In: REUNIÃO ANUAL DA SOCIEDADE BRASILEIRA DE ZOOTECNIA, 39. , Recife, 2002, Anais. Recife: Ed. dos Editores, 2002. 
MENDES NETO, J.; CAMPOS, J. M. S.; QUEIROZ, A. C.; VALADARES, S. C. F.; LANNA, R. P.; ROCHA, K. D. Efeito da substituição do feno de Tifton 85 por polpa de citrus. 3. comportamento ingestivo. In: REUNIÃO ANUAL DA SOCIEDADE BRASILEIRA DE ZOOTECNIA, 38. , Piracicaba, 2001. Anais..Piracicaba: FEALQ, 2001. p.1274-1275.

MERTENS, D. R. Creating a system for meeting the fiber requirements of dairy cows. Journal of Dairy Science, v.80, p.1463-1481, 1997.

MICHAL, J. J.; JOHNSON, K. A; TREACHER, R. J.; GASKINS, C. T.; SEARS, O. The impact of direct-fed fibrolytic enzymes on the growth rate and feed efficiency of growing beef steers and heifers. Journal of Animal Science, v.74, suppl. 1, p.296, 1996.

MILLER, W.J.; CLIFTON, C.M. Relation of dry matter content in ensiled material and other factors in nutrient losses by seepage. Journal of Dairy Science, v.48, p.917-923, 1965.

MIRANDA, L. F.; QUEIROZ, A. C.; VALADARES, S. C. F.; CECON, P. R.; PEREIRA, E. S.; CAMPOS, J. M. S.; LANNA, R. P.; MIRANDA, J. R. Comportamento ingestivo de novilhas leiteiras alimentadas com dietas à base de cana-de-açúcar. Revista Brasileira de Zootecnia, v.28, n.3, p.614-620, 1999.

MOORE, J. A.; POORE M. H.; SWINGLE R. S. Time-saving procedure for determining dry matter and neutral detergent fiber content in residues from in situ incubations. Journal of Animal Science, v.65, suppl. 1, p.487. 1987. 
MORGAVI, D. P.; BEAUCHEMIN, K. A.; NSEREKO, V. L.; RODE, L. M.; IWAASA, A. D.; YANG, W. Z.; McALLISTER, T. A.; WANG, Y. Synergy between ruminal fibrolytic enzymes and enzymes from Trichoderma Longibrachiatum. Journal of Dairy Science, v.83, p.1310-1321, 2000.

MOSER, L.E. Post-harvest physiological change in forage plants. In: MOORE, K.K; KRAL, D.M.;VINEY, M.K. (Ed.). Post-harvest physiology and preservation of forages. Madison: American Society of Agronomy, 1995. p.1-19.

MOULD, F. L.; ORSKOV, E. R. Manipulation of rumen fluid $\mathrm{pH}$ and its influence on cellulolysis in sacco, dry matter degradation and the rumen microflora of sheep offered either hay or concentrate. Animal Feed Science and Technology. v. 10, p.1-14, 1983.

MUCK, R. E.; HOLMES, B. J. Factors affecting bunker silo densities. Applied Engineering in Agriculture. v. 16, n.6, p.613-619, 2000.

MUCK, R. E.; HOLMES, B. J. Density and losses in pressed bag silos. In: ANNUAL INTERNATIONAL MEETING SPONSORED. Sacramento, 2001. Meetings. Sacramento : ASAE, 2001. 20p.

MUCK, R. E.; KUNG, L. JUNIOR. Effects of silages additives on ensiling. In: THE SILAGE: FIELD TO FEED BUNK NORTH AMERICAN CONFERENCE. Hershey, 1997. Proceedings. Hershey: National Regional Agricultural Engineering Service. 1997. p. 187-199.

MÜHLBACH, P. R .F. Uso de silagens na produção animal.. In: CICLO DE PALESTRAS EM PRODUÇÃO E MANEJO DE BOVINOS DE CORTE, 3. Canoas, 1998. Anais. Canoas, Universidade Luterana do Brasil, 1998. p.40-53. 
NADEAU, E. M. G.; BUXTON, D. R.; RUSSELL, J. R.; ALLISON, M. J.; YOUNG, J. W. Enzyme, bacterial inoculant, and formic acid effects on silage composition of orchardgrass and alfalfa. Journal of Dairy Science, v.83, p.1487-1502, 2000.

NATIONAL RESEARCH COUNCIL. Nutrients Requirements of Beef Cattle. 7.ed. Washington: National Academy of Sciences, 1996. 242p.

NELSON, W. F.; SATTER, L. D. Impact of stage of maturity and method of preservation of alfalfa on digestion in lactating dairy cows. Journal of Dairy Science, v.75, p.1571-1580, 1992.

NSEREKO, V. L.; MORGAVI , D. P.; BEAUCHEMIN K. A; RODE, L. M.; FURTADO, A. F. Inhibition of fungal feed enzyme activities by silage extracts. Canadian Journal of Animal Science, v.78, suppl. 1, p.265, 2000.

NSEREKO, V. L.; BEAUCHEMIN K. A.; MORGAVI, D. P.; RODE, L. M.; FURTADO, A. F.; McALLISTER T. A.; IWAASA, A. D. YANG W. Z.; WANG Y. Effect of a fibrolytic enzyme preparation from Trichoderma longibrachiatum on the rumen microbial population of dairy cows. Canadian Journal of Animal Science, v.48, p.14-20, 2002.

NUSSIO, L.G; PAZIANI, S.F.; NUSSIO, C. M. B. Ensilagem de capins tropicais. In: REUNIÃO ANUAL DA SOCIEDADE BRASILEIRA DE ZOOTECNIA. 39. , Recife, 2002. Anais. Recife: BATISTA, A. M. V., BARBOSA S. B. P., dos SANTOS M. V. F., FERREIRA L. M. C., 2002. p. 60-83.

NUSSIO, L. G.; HUBER, J. T.; THEURER, C. B.; NUSSIO, C. B.; SANTOS, J.; TARAZON, M.; LIMA-FILHO, R. O.; RIGGS, B.; LAMAREAUX, M. Influence of a cellulase/xylanase complex $(\mathrm{C} / \mathrm{X})$ on lactational performance of dairy cows fed alfalfa hay (AH) based diets. Journal of Dairy Science, v.80, suppl. 1, p.220, 1997. 
O’DONNELL, C.; WILliAMS, A. G., BIDDLESTONE, A. J. The effects of pressure and stage of ensilage on the mechanical properties and effluent production potential of grass silage. Grass and Forage Science, v.52, p.12-26. 1997a.

O’DONNELL, C.; WILLIAMS, A. G., BIDDLESTONE, A. J. The effects of temperature on the effluent production potential of grass silage. Grass and Forage Science, v.52, p.343-349. 1997b.

O’KIELY, P.; CLANCY M.; DOYLE E. M. Aerobic stability of grass silage mixed with a range of concentrate feedstuffs at feed-out (compact disc). In: INTERNATIONAL GRASSLAND CONGRESS, 19., São Pedro, 2001. Anais. Piracicaba: FEALQ, 2001 (Forage Conservation. Papers, ID 21-28)

O'KIELY, P.; MOLONEY, A.; O’RIORDAN, E. G. Reducing the cost of beef production by increasing silage intake. Dunsany: Grange Research Centre, 2002, 116p. (Beef Production Series, 51)

O’KIELY, P.; MOLONEY, A.; KEATING, T. SHIELS P. Maximizing output of beef within cost efficient, environmentally compatible forage conservation systems. Dunsany: Grange Research Centre, 1999, 64p. (Beef Production Series, 10)

OKUDA, H.; FUGI, S.; KAWASHIMA. A direct colorimetric method for blood ammonia. Journal of experimental medicine. v 12, n.1, p.11-23,1965.

ORSKOV, E. R. Curve fitting software for in sacco degradability and in vitro gas production data. http://www.mluri.sari.ac.uk/IFRU/fcurve.html (20 Nov. 2002)

ORSKOV, E. R.; McDONALD, I. The estimation of protein degradability in the rumen from incubation measurements weight according to rate of passage. Journal of Agricultural Science, Cambridge, v.92, p.499-503, 1979. 
PALMQUIST, D. L.; CONRAD, H. R. Origin of plasma fatty acids in lactating cows fed high grain fat diets. Journal of Dairy Science, v.54, p.1025-1033, 1971.

PAZIANI, S. F.; NUSSIO, L. G. Parâmetros físicos em silos tipo “bag”. http://www.beefpoint.com.br/bn/radarestecnicos/artigo.asp?nv=1\&area=12\&area_de sc=Conserva\%E7\%E3o+de+Forragens\&id_artigo=5998\&perM=10\&perA=2003 (11 out 2002)

PEREIRA, J. R. A.; REIS, R. A. Produção e utilização de silagem pré-secada. http://www.nucleoestudo.ufla.br/nefor/anais/Palestra08.pdf. (20 Dec. 2002)

PFLAUM, J.; HONIG, H.; PAHLOW, G.; STAUDACHER, W. A comparison of the aerobic stability of maize silage produced in laboratory and farm silos. In: INTERNATIONAL SILAGE CONFERENCE, 23., Auchincruive, 2002. Proceedings. Auchincruive: SAC, 2002. p.180-181.

PHUNTSOK, T.; FROETSCHEL, M.A.; AMOS, H. E.; ZHENG, M.; HUANG, Y. W. Biogenic amines in silage, apparent postruminal passage, and the relationship between biogenic amines and digestive function and intake by steers. Journal of Dairy Science, v.81, p.2193-2203, 1998.

PINOS, R. J.; GONZÁlEZ, S.; MENDOZA, G.; COBO, M.; BÁCENA, R.; HERNÁNDEZ, A.; MARTÍNEZ, A. ORTEGA, M.; HOYOS, G.; JACQUES, K. Effect of a fibrolytic supplement (fibrozyme) on intake and apparent digestibility of alfalfa and ryegrass fed to lambs. Journal of Animal Science, v.78, suppl. 1, p.275. 2000. 
PITT, R. E. Additives for silage and hay preservation. In: SILAGE AND HAY PRESERVATION, New York, 1990a. NRAES-5. New York: Ithaca, 1990. p.28-44.

PITT, R.E., PARLANGE, J.Y. Effluent production from silage with application to tower silos. Transactions of the American Society of Agricultural Engineers, v. 30, p.1198-1204, 1987.

PRITCHARD, G.; HUNT, J. T.; ALLEN, A.; TREACHER, R. Effect of direct-fed fibrolytic enzymes on digestion and growth performance in feed cattle. Journal of Animal Science, v.74, suppl. 1, p.296, 1996.

RANGRAB, L. H.; BERTO, J. L.; MUHLBACH, P. R. F., da SILVA, A. L. B. Silagem de alfafa (Medicago sativa) no estádio de início de florescimento submetida a ação de aditivos biológicos e ao efeito de emurchecimento. http://www.sbz.org.br/ eventos/Fortaleza/ForragiculturalSbz585.pdf (12 Dec. 2002)

RIBEIRO, K. G.; PEREIRA, O. G.; VALADARES, S. C. F.; GARCIA, R; CECON, P. R. Eficiência microbiana, fluxo de compostos nitrogenados no abomaso, amônia e $\mathrm{pH}$ ruminais, em bovinos recebendo dietas contendo feno de capim Tifton 85 de diferentes idades de rebrota. Revista Brasileira de Zootecnia, v.30, n.2, p.581-588, 2001.

REIS, R. A.; JOBIM C. C. Perfil da fração de carboidratos da planta e adequação de aditivos no processo de ensilagem. In: WORKSHOP SOBRE MILHO PARA SILAGEM, 2. , Piracicaba, 2000. Anais. Piracicaba: FEALQ, 2000. p.27-51.

RODE, L. M.; BEAUCHEMIN, K. A. Enzymes to enhance utilization of feed in dairy cows. http://mas.ualberta.ca/weds/wed98/ch15htm (02 Dec. 1999) 
RODE, L. M; YANG, W. Z.; BEAUCHEMIN, K. A. Fibrolytic enzyme supplements for dairy cows in early lactation. Journal of Dairy Science, v.82, p.2121-2126, 1999.

ROTZ, C.A., PITT, R. E.; MUCK, E. M.; ALLEN, M.; BUCKMASTER, D. R. Directcut harvest and storage of alfalfa on the dairy farm. Transactions of the American Society of Agricultural Engineers, v. 36, n.3 , p.621-628. 1993.

SAMPAIO, I. B. M. Contribuições estatísticas e de técnica experimental para ensaios de degradabilidade de forragens quando avaliada in situ. In: REUNIÃO ANUAL DA SOCIEDADE BRASILEIRA DE ZOOTECNIA, 31. , Maringá, 1994. Anais. Maringá: UEM, 1994. p.81-88.

SANCHES, W. K.; HUNT C. W.; GUY, M. A.; PRITCHARD, G T.; SWANSON, B. I.; WARNER, T. B.; HIGGINS, J. M.; TREACHER, R. J. Effect of fibrolytic enzymes on lactational performance in dairy cows. Journal of Dairy Science, v.79 , suppl. 1, p.183, 1996.

SAS INSTITUTE. SAS OnlineDoc - Version eight http://www.smoo.ciagri.usp.br/ sasdoc/sashtml/welcome.htm. (15 Nov. 2002)

SATTER, L. D. ; SLYTER, L. L. Effect of ammonia concentration on rumen microbial protein production in vitro. British Journal of Nutrition, v. 32, n.2, p.199-208. 1974.

SCHINGOETHE, D. J.; STEGEMAN, G. A.; TREACHER, R. J. Response of lactating dairy cows to a cellulase and xylanase enzyme mixture applied to forages at the time of feeding. Journal of Dairy Science, v. 82, p.996-1003, 1999. 
SHEPERD, A. C.; KUNG, L. JUNIOR. Effects of an enzyme additive on composition of corn silage ensiled at various stages of maturity. Journal of Dairy Science, v. 79, p.1767-1773, 1996.

SHEPERD, A. C.; MASLANKA, M.; QUINN, D.; KUNG, L. JUNIOR. Additives containing bacteria and enzymes for alfalfa silage. Journal of Dairy Science, v. 78, p.565-572, 1995.

SILVA, D. J. Análise de alimentos: métodos químicos e biológicos. Viçosa: Impr. Universitária, 1990. 165p.

SILVA, M. O. S. A. Análises físico-químicas para controle de estação de tratamentos de esgotos. São Paulo: CETESB, 1977. 266p.

SIMILI, F. F.; LIMA, M. L. P.; NOGUEIRA; J. R.; LEME, P. R.; SANTOS, A. L. ; LIMA, N. C.; BERCHIELLI, T. T. Degradabilidade in situ do capim elefante var. Guaçu e capim Tanzânia (compact disc). In: REUNIÃO ANUAL DA SOCIEDADE BRASILEIRA DE ZOOTECNIA, 39. , Recife, 2002, Anais. Recife: Ed. dos Editores, 2002.

STEFANIE, J. W. H.; ELFERINK, O.; DRIEHUIS, F.; GOTTSCHAL, J. C., SPOELSTRA, S. F. Silage fermentation processes and their manipulation. In: FAO ELECTRONIC CONFERENCE ON TROPICAL SILAGE, Rome, 1999. Proceedings. Rome: FAO, 2000. p.17-30.

STOKES, M. R. Effect of an enzyme mixture, an inoculant, and their interaction on silage fermentation and dairy production. Journal of Dairy Science, v.75, p.764773, 1992. 
SUTTON, J. D.; PHIPPS, R. H.; BEEVER, D. E.; HUMPHRIES, D. J.; HARTNELL, G. F.; VICINI, J. L.; HARD, D. L. Effect of method of application of a fibrolytic enzyme product on digestive process and milk production in Holstein-Friesian cows. Journal of Dairy Science, v.86, p.546-556, 2003.

TAMADA, J.; YOKOTA, H.; OHSHIMA, M.; ATAKU K.; TAMAKI, M. Effect of additives, storage temperatures and regional difference of ensiling on the fermentation quality of napier grass (Pennisetum purpureum, Schum.) silage. AJAS, v.12,n.1, p.28-35,1999.

TAYLOR, C.C.; RANJIT, N. J.; MILLS, J. A.; NEYLON, J. M.; KUNG JUNIOR., L. The effect of treating whole-plant barley with Lactobacillus buchneri 40788 on silage fermentation, aerobic stability, and nutritive value for dairy cows. Journal of Dairy Science, v.85, p.1793-1800, 2002.

THIAGO, L. R. L. S. Utilização da técnica de degradabilidade in situ para a avaliação de forragens e alimentos concentrados. In: REUNIÃO ANUAL DA SOCIEDADE BRASILEIRA DE ZOOTECNIA, 31., Maringá, 1994. Anais. Maringá: UEM, 1994. p.89-93.

TOSI P.; TOSI H.; MATTOS, W. R. S.; JOBIM, C. C.; LAVEZZO, W. Ensilagem do capim-elefante cv Taiwan A-48, com diferentes técnicas de redução de umidade. http://www.sbz.org.br/anais1997/Nru/BNRU192.pdf. (05 Dez. 2002)

TREACHER, R. J.; HUNT, C. W. Recent developments in feed enzymes for ruminant rations - with special reference to direct-fed applications. In: PACIFIC NORTHWEST NUTRITION CONFERENCE, Seattle. 1996. Proceedings. Seattle: WA, 1996. p.1-19. 
UDÉN, P.; COLUCCI P.E.; VAN SOEST P.J. Investigation of chromium, cerium, and cobalt as markers in digesta. Rate of passage studies. Journal of the Science of Food and Agriculture, v. 31, n.7, p. 625-632, 1980.

UMANA R., STAPLES C. R, BATES D. B.; WILCOX C. J.; MAHANNA, W. C. Effects of a microbial inoculant and (or) sugarcane molasses on the fermentation, aerobic stability, and digestibility of bermudagrass ensiled at two moisture contents. Journal of Animal Science, v.69, p.4588-4601, 1991.

URIARTE-ARCHUNDIA, M. E.; BOLSEN, K. K.; BRENT, B. E. A study of the chemical and microbial changes in whole-plant maize silage during exposure to air: effects of stage of maturity, packing density and sealing technique. In INTERNATIONAL SILAGE CONFERENCE, 23., Auchincruive, 2002a. Proceedings. Auchincruive: SAC, 2002a. p.172-173.

URIARTE-ARCHUNDIA, M. E.; BOLSEN, K. K.; BRENT, B. E. A study of the chemical and microbial changes in whole-plant maize silage during exposure to air: effects of a biological additive and sealing technique. In: INTERNATIONAL SILAGE CONFEREnCE, 23., Auchincruive, 2002b. Proceedings. Auchincruive: SAC, 2002b. p.174-175.

VAN SOEST, P. J.; ROBERTSON, J. B.; LEWIS, B. A. Methods for dietary fiber, neutral detergent fiber, and non-starch polysaccharides in relation to animal nutrition. Journal of Dairy Science, v.74, p.3583-3597, 1991.

VAN SOEST, P. J. Nutritional ecology of the ruminants. Ithaca: Cornell University, 1994. 476p. 
VICINI, J. L.; BATEMAN, H. G.; BHAT, M. K.; CLARK, J. H.; ERDMAN, R. A.; PHIPPS, R. H.; VAN AMBURGH, M. E.; HARTNELL, G. F.; HINTZ, R. L.; HARD, D.L. Effect of feeding supplemental fibrolytic enzymes or soluble sugars with malic acid on milk production. Journal of Dairy Science, v.86, p.576-585, 2003.

VILELA, D. Aditivos para silagens de plantas de clima tropical. In: REUNIÃO ANUAL DA SOCIEDADE BRASILEIRA DE ZOTECNIA, 35., Botucatu,1998. Anais. Botucatu: SBZ, 1998. p.73-108.

WALLACE, R.J; HARTNELL, G.F. Technical note: methods for detecting liquid enzyme additives added to animal feeds. Journal of Dairy Science, v.79, p. 27312735, 2001.

WALLACE, R. J.; WALLACE, S. J. A.; McKAIN, N.; NSEREKO, V. L.; HARTNELL, G. F. Influence of supplementary fibrolytic enzymes on the fermentation of corn and grass silages by mixed ruminal microorganisms in vitro. Journal of Animal Science, v.79, p.1905-1916, 2001.

WANG, Y.; SPRATLING, B. M.; ZOBELL, D. R.; WIEDMEIER, R. D.; McALLISTER, T. A. Effect of alkali pretreatment of wheat straw on the efficacy of exogenous fibrolytic enzymes. Journal of Animal Science, v.82, p.198-208, 2004.

WILES. P. G.; GRAY, I. K ; KISSLING, R. C. Routine analysis of protein by Kjeldahl and Dumas methods: review and interlaboratory study using dairy products. Journal of AOAC International, v.81, n.3, p.620-632, 1998.

WILLIAMS, A. G. HOVEY, R.P. ; LOWE, J. F. Changes in temperature end silo gas composition during ensiling, storage and feeding-out grass silage. Grass and Forage Science, v.52, p.176-189, 1997. 
WOOLFORD, M.K. The silage fermentation. New York: Marcel Dekker, 1984. 322p.

WYSS, U. Influence of different factors on aerobic stability of maize silages. In: INTERNATIONAL SILAGE CONFERENCE, 23., Auchincruive, 2002. Proceedings. Auchincruive: SAC, 2002. p.176-177.

YANG, W. Z., BEAUCHEMIN K. A.; RODE, L. M. Effects of enzyme treatment or grain source on lactation and digestion of dairy cows. Journal of Dairy Science, v.80, suppl. 1, p.210, 1997.

YANG, W. Z., RODE, L. M.; BEAUCHEMIN K. A. Effects of fibrolytic enzymes additives on milk production of dairy cows. Journal of Dairy Science, v.76, suppl. 1, p.320, 1998.

YANG, W. Z.; BEAUCHEMIN, K. A.; RODE, L. M. Effects of an enzymes feed additive on extent of digestion and milk production of lactating dairy cows. Journal of Dairy Science, v.82, p.391-403, 1999.

YANG, W. Z.; BEAUCHEMIN, K. A.; RODE, L. M. Effects of barley grain processing on extent of digestion and milk production of lactating cows. Journal of Dairy Science, v.83, p.554-568, 2000.

YANG, W. Z., BEAUCHEMIN K. A.; RODE, L. M. Comparison of methods of adding fibrolytic enzymes to lactating cow diets. Journal of Dairy Science, v.83, p.25122520, 2001a.

YANG, W. Z., BEAUCHEMIN K. A.; RODE, L. M. Effects of grain processing, forage to concentrate ratio, and forage particle size and digestion by dairy cows. Journal of Dairy Science, v.84, p.2203-2216, $2001 b$. 
YANG, W. Z., BEAUCHEMIN K. A.; RODE, L. M. Effects of particle size of alfalfabased dairy cow diets on site and extent of digestion. Journal of Dairy Science, v.85, p.1958-1968, 2002a.

YANG, W. Z., BEAUCHEMIN K. A.; VEDRES, D. D. Effects of $\mathrm{pH}$ and fibrolytic enzymes on digestibility, bacterial protein synthesis, and fermentation in continuous culture. Animal Feed Science and Technology, v.102, p.137-150, 2002b.

YANG, W. Z.; GORDON, F. J.; DAWSON, L. E. R.; FERRIS, C. P.; STEEN, R W. J.; KILPATRICK, D. J. Effects of wilting and additive type on energy of grass silage by growing cattle. http://www.bsas.org.uk/meeting/annuproc/pdf99/035.pdf Jan. 2003)

ZASTAWNY, J.; JASNIEWICZ, P.; WRÓBEL, B. Quality and aerobic stability of grass silage made with bacterial inoculants containing lactic acid bacteria. In: INTERNATIONAL SILAGE CONFERENCE， 23., Auchincruive, 2002. Proceedings. Auchincruive: SAC, 2002. p.186-187.

ZHENG, S.; STOKES M. R. Effects of fibrolytic enzymes on feed stability and performance of lactation and digestion of dairy cows. Journal of Dairy Science, v.80, suppl. 1, p.278, 1997.

ZHENG, W.; SCHINGOETHE, D. J.; STEGEMAN, G. A.; HIPPEN, A.R.; TREACHER R. J. Determination of when during the lactation cycle to start feeding a cellulase and xylanase enzyme mixture to dairy cows. Journal of Dairy Science, v.83, p.23192325, 2000.

ZOBELL; D. R.; WIEDMEIER, R. D.; OLSON, K. C.; TREACHER, R. The effect of an exogenous enzyme treatment on production and carcass characteristics of growing and finishing steers. Animal Feed Science and Technology, v.87, p.279-285, 2000. 